\title{
WATER-RESOURCES INVESTIGATIONS OF THE U.S. GEOLOGICAL SURVEY IN WYOMING, FISCAL YEAR 1979
}

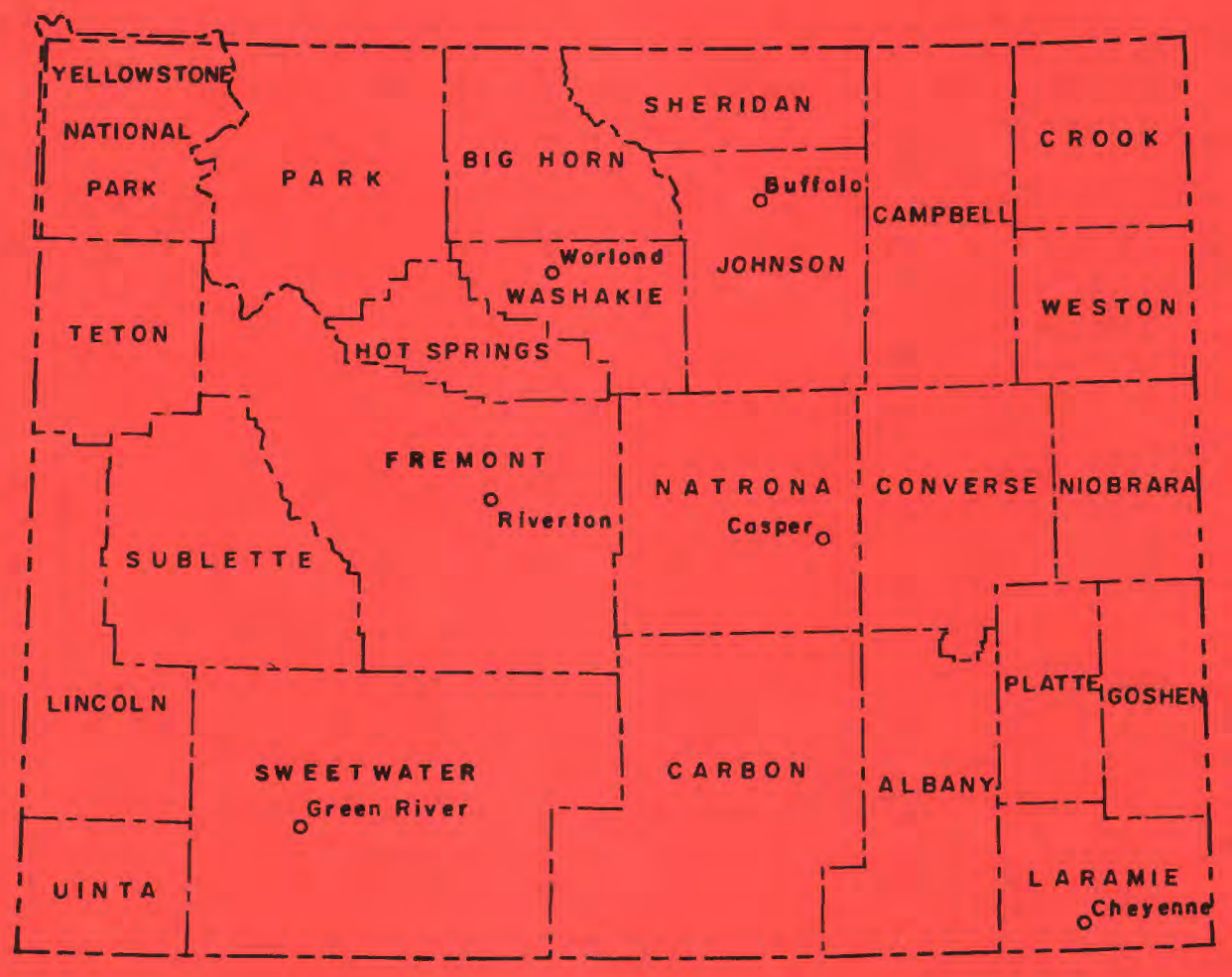

U.S. GEOLOGICAL SURVEY

Open-File Report $79-1278$
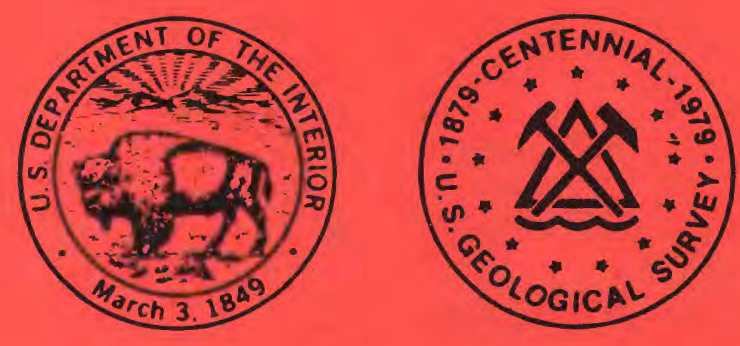
UNITED STATES

DEPARTMENT OF THE INTERIOR

GEOLOGICAL SURVEY

WATER-RESOURCES INVESTIGATIONS OF THE

U.S . GEOLOGICAL SURVEY IN WYOMING,

FISCAL YEAR 1979

By D. D. Carlson and S. L. Green

Open-File Report 79-1278

Cheyenne, Wyoming 


\title{
UNITED STATES DEPARTMENT OF THE INTERIOR
}

\author{
CECIL D. ANDRUS, Secretary \\ GEOLOGICAL SURVEY \\ H. William Menard, Director
}

\section{COOPERATING AGENCIES}

State Agencies

Wyoming Department of Agriculture

Wyoming Department of Economic Planning and Development

Wyoming Department of Environmental Quality

Wyoming Department of Game and Fish

Wyoming Highway Department

Wyoming State Engineer

Wyoming Water Resources Research Institute

Municipality

City of Cheyenne

Federal Agencies

Bureau of Land Management

Bureau of Reclamation

Corps of Engineers

Department of Energy

Environmental Protection Agency

Fish and Wildlife Service

National Park Service 
Introduction- 1

A brief history of the Wyoming District-___ 2

District office addresses-_- 5

Wyoming District organization chart-_ 6

Where to obtain U.S. Geological Survey publications-----_---_- 7

Data-collection sites-_- 8

Water-resources projects-- 55

Water-resources projects conducted by the Wyoming District- 56

Surface-water stations (WY 00-001)-- 57

Ground-water stations (WY 00-002)- 58

Water-quality stations (WY 00-003)-__ 60

Sediment stations (WY 00-004)-___- 61

Flood investigations in Wyoming (WY 59-010)--_-_-_- 63

Hydrologic evaluation of the Arikaree Formation near Lusk, Wyoming (WY 74-024)-_ 64

Water resources of Weston County, Wyoming (WY 74-026)- 65

Monitoring wastewater effluent in Yellowstone and

Grand Teton National Parks, Wyoming (WY 74-027)---- 67

Water and its reiation to economic development in

the Green River and Great Divide basins in

Wyoming (WY 75-030)-_-

Impacts of economic development and water use on water resources in the Hanna basin in Wyoming (WY 75-031)--

Water resources of the Powder River structural basin in Wyoming in relation to energy development (WY 75-032)--

Hydrology of Paleozoic rocks in the Powder River basin and adjacent areas, northeastern Wyoming (WY 75-033)

(1)

(1)

(1)

8

Evaluation of Paleozoic and alluvial aquifers in the Bighorn Basin, Wyoming (WY 75-034)- 74

Algal-growth potential of principal North Platte River reservoirs in Wyoming (WY 76-035)-_- 76

Quantitative study of the Tertiary aquifers in southern Laramie County, Wyoming (WY 77-038)-- 77

Water-resources monitoring in the Powder River, south-central, and southwestern coal regions in Wyoming (WY 77-039)--

Effects of herbicide usage on water quality of selected streams in Wyoming (WY 77-043)--

A preliminary hydrologic investigation of an in-situ oil-shale retorting site near Rock Springs, Wyoming (WY 78-045)- 
Water-resources projects--continued

Water-resources projects conducted by the Wyoming

District--continued

Digital model of the Arikaree aquifer in Muleshoe

Flat, southeastern Wyoming (WY 78-046)-- 82

Digital model of the alluvial aquifer in Bates Hole, central Wyoming (WY 78-047)- 83

Digital model of the hydrologic system in the La Grange area, southeastern Wyoming (WY 78-048)--- 85

Northern Great Plains regional aquifer-system analysis, Wyoming (WY 78-049)-_- 86

High Plains regional aquifer-system analysis, Wyoming (WY 78-050)

Rate of nutrient release from decomposing plankton and periphyton in lake De Smet and its outflow, north-central Wyoming (WY 78-051)

Hydrologic conditions in the Wheatland Flats Area, Platte County, Wyoming, Part II (WY 79-052)-_-_- C0

Water-resources projects conducted by other districts----- 92

Yampa River basin assessment, northwestern Colorado and south-central Wyoming (CO 75-075)--- S3

Effects of mining and related activities on the shallow ground-water system (MT 75-048)-_- 95

Avallability of ground water from aquifers in the Cretaceous and Tertiary systems in the Fort Union coal region (ND 75-071)-

Hydrology of the aquifer(s) in the Madison Group (SD 76-043)

Water-resources projects conducted by Central Region Staff- 100

Geochemical survey of waters of the western coal regions (CR 74-095)

Bedload transport research (CR 74-187)--_-_-_-_-- 102

Reconnaissance techniques for evaluation of rehabilitation potential of energy resource lands (CR 75-104)

Sorption of residual organic substances in retort waters by spent oil-shale residues (CR 75-181)------ 106

Hydrology of the Madison Limestone and associated rocks in parts of Montana, North Dakota, South Dakota, and Wyoming (CR 76-192)

High Plains regional aquifer-system analysis (CR 78-229)

Northern Great Plains regional aquifer assessment (CR 78-230) 


\section{ILLUSTRATIONS}

Page

Figure 1. Map showing location of offices in Wyoming-- 5

2. Wyoming District organization chart- 6

Figures 3-7. Maps showing location of surface-water data sites in

3. The Yellowstone River, Clarks Fork Yellowstone River, and Bighorn River basins-_- 9

4. The Tongue River, Powder River, Belle Fourche River, and Cheyenne River basins-_- 10

5. The Niobrara River and Platte River basins--.- 11

6. The Green River and Bear River basins-_-_-_- 12

7. The Snake River basin-_- 13

8-11. Maps showing locations of ground-water stations in

8. The Yellowstone River, Clarks Fork Yellowstone River, and Bighorn River basins-_-_- 22

9. The Tongue River, Powder River, Belle Fourche River, and Cheyenne River basins-_- 23

10. The Niobrara River and Platte River basins---- 24

11. The Green River and Bear River basins-_-_-_-_ 25

\section{TABLES}

Page

Table 1. Surface-water stations-_ 15

2. Ground-water stations-_- 27

3. Water-quality stations-_- 38

4. Sediment stations-_- 46

5. Peak-flow partial-record stations-_- 51 


\section{WATER-RESOURCES INVESTIGATIONS OF THE \\ U.S. GEOLOGICAL SURVEY IN WYOMING,}

FISCAL YEAR 1979

by D. D. Carlson and S. L. Green

\section{INTRODUCTION}

The Water Resources Division of the U.S. Geological Survey is the Federal agency responsible for appraising the quantity, quality, and distribution of our surface-water and ground-water resources. The division conducts interpretive studies, supports hydrologic research, and maintains data-collection networks in every State; it also works through cooperative programs with State, local, and other Federal agencies agencies to help evaluate or solve regional and local water problems. Results of its investigations provide a basis for nearly all major public water-management decisions.

The U.S. Geological Survey, in cooperation with the State of Wyoming, the city of Cheyenne, and other Federal agencies, has five datacollection activities and 31 water-resource appraisal projects in Wyoming during fiscal year 1979 (October 1, 1978, through September 30, 1979).

The data-collection activities include: (1) Collection of records for streamflow and reservoir storage; (2) measurements of water levels in wells; (3) sampling and chemical analysis of water from streams and wells; (4) sampling and sediment analysis of surface water; and (5) collection of peak-flow information at partial-record sites. This report contains tables of monitoring sites for these five data-collection activities.

Water resource appraisal projects described in the report include the projects currently being conducted during fiscal year 1979 and projects completed in previous fiscal years, but for which final reports are in preparation.

The purpose of this report is to describe the water-resource work being done in Wyoming. The report is also intended to inform cooperating officials and the public about the accomplishments in the various investigations during the fiscal year 1979 (October 1, 1978, through September 30,1979$)$. It is one phase of an effort to coordinate the water-resources investigations of the U.S. Geological Survey with those of other organizations. 


\section{A BRIEF HISTORY OF THE WYOMING DISTRICT}

On March 3, 1879, President Rutherford B. Hayes signed a bill establishing the U.S. Geological Survey. The Sundry Civil Appropriation Act of 1888 established an Irrigation Survey as a part of the U.S. Geological Survey "for the purpose of investigating the extent to which the arid region of the United States can be redeemed by irrigation ***." The Water Resources Division, of which the Wyoming District is a part, has its roots in the Irrigation Survey of 1888-1890. The following summary of the water-resources activities of the U.S. Geological Survey in Wyoming is included in this report in commemoration of the $100 \mathrm{th}$ anniversary of the U.S. Geological Survey.

There was no Wyoming District in 1888, when the Washington, D. C. office of the Survey paid the installation costs for the first gaging station in Wyoming, Laramie River at Woods Landing. It was constructed and operated by the Territorial Engineer, Elwood Mead. Between 1895 and 1901 the Survey paid operating expenses for additional stations operated by the State Engineer. A. J. Parshall became the first resident hydrographer for the Survey in Wyoming in 1901. For the next six years there was no cooperative work with the State, but 11 stations were operated with Survey and Reclamation Service funds. By 1912 the Survey's network consisted of 50 stations, including 21 in cooperation with the State Engineer. Parshall was appointed State Engineer; surprisingly, he refused to allow the Survey to use any part of its share of the funts to pay office expenses, so cooperation ended in 1912. The first official letter written by J. B. True as the new State Engineer in 1915 was to the Survey, urging resumption of the coop program. Fifty gaging stations were established or re-established; cooperation with the State Engineer has continued without further interruption.

Early Federal cooperators included the Indian Service (1908) and the Forest Service (1910). In 1938 the Bureau of Reclamation established 23 streamflow stations in the Green River Basin using Survey plans. The Bureau also did field work at Survey stations in the area; in return the Survey computed and published the records for all stations. During the postwar period, 1945-50, many new streamflow stations were established under the Interior Department's Missouri River Basin program. A floodinvestigations program, started in 1959 in cooperation with the Wyoning Highway Department, has continued to the present.

Surface-water activities in Wyoming were directed from Washington until 1903, when the Denver District was established under M. C. Hinderlider. Between 1903 and 1961 Wyoming was part of the Colorado District, with local offices at various times in Kemmerer, Sheridan, and Casper. The Wyoming District, Surface Water Branch, was establishet in 1961, with L. A. Wiard as District Engineer. 
The earliest known ground-water studies by the Survey in Wyoming were done between 1900 and 1917 by G. I. Adams in the Goshen Hole area (Water-Supply Paper 70); N. H. Darton in the Great Plains, Bighorn Mountains, Laramie Range, and Black Hills; and 0. E. Meinzer in Lodgepole Valley. State cooperation has been continuous since 1940, when the Wyoming Planning and Water Conservation Board sponsored a study of the Egbert-Pine Bluffs area by T. W. Robinson. Cooperation with the State Engineer has continued since 1945. In 1959 all State cooperative groundwater work was consolidated under the State Engineer program. Ground-water work for other Federal agencies has included measurements of discharge and power consumption for REA in 1941, many investigations since 1946 for the $^{-}$the Bureau of Reclamation under the Interior Department's Missouri River Basin Program, and a continuous series of studies of Yellowstone and Grand Teton National Parks for the National Park Service since the early 1960's.

Ground-water work in Wyoming was directed from Washington until 1945, when Wyoming became a part of the Colorado District under S. W. Lohman. The local geologist in charge was A. M. Morgan. In 1951 (?) the Wyoming District, Ground Water Branch, was established, with H. M. Babcock as District Geologist.

Surface-water quality work in Wyoming began with the establishment of an office in Worland in March 1945, with T. F. Hanly in charge. The program was directed by $P$. C. Benedict, Regional Engineer, in Lincoln, Nebraska. In 1948, the chemical quality or sediment stations were ir operation at 16 sites in the Bighorn Basin and 5 sites in the North Flatte basin, under the Department's Missouri River Basin program. By 1953, the program included $39 \mathrm{CQ}$ stations and 42 sediment stations.

In February 1956 Worland became a District Office, Quality of Weter Branch, with a field office in Riverton; the Riverton office was reassigned to the Surface Water Branch in October 1964. The first sediment station in the State coop program was established on Rock Creek near Atlantic Cj.ty for the Wyoming Natural Resources Board in 1957. The State Engineer started a cooperative chemical-quality program to evaluate the effects of the Kendrick Project on the North Platte River in 1959. Since 1965 the Wyoming Department of Agriculture has been principal State Cooperator for chemical quality and the State Engineer for sediment data. In 1966 water-quality work in the Green River basin, previously done by the Utah District, was transferred to the Wyoming District.

The District sediment laboratory has remained in Worland since the office was opened, and today serves the Montana and North Dakota Districts as well. The chemical lab moved to Cheyenne in 1959 and was immediately downgraded because of the establishment of the WRD Central Laboratory in Salt Lake City. Since 1966, however, basic salinity analyses of samfles collected for the State programs have been done by the State laboratcry in Laramie for Direct Services credit in the program with the Wyoming Department of Agriculture. 
The Branch districts were combined into a single WRD district in February 1967. The programs and staff of the District changed 1ittle until 1974. Within two years the staff doubled and the budget tripled, mostly in response to the pending boom in development of coal and other energy resources. The water-quality data program, in particular, irnreased several-fold. Significant new programs were started in cooperation with the Wyoming Department of Envirommental Quality, the Bureau of Land Management, and the Environmental Protection Agency.

Today the District has approximately 70 employees, with field cffices in Buffalo, Casper, Green River, Riverton, and Worland. Approximately half of the funding is for work for other agencies, and half is for participation in the Survey' energy programs and regional aquifer assessments. Reconnaissance and inventory studies have given way to problemoriented, multidisciplinary studies and increased use of digital models. For the immediate future the impacts of coal and uranium mining, the. effects of human activity on water quality, and the increased develcoment of ground water for irrigation will occupy much of the Wyoming District's effort.

The District Chiefs who have directed the Wyoming District are listed below:

Surface Water Branch:

Ground Water Branch:

Quality of Water Branch:

Water Resources Division:
Leon A. Wiard

Horace M. Babcock

E11is D. Gordon

Thomas F. Hanly

Leon A. Wiard

Robert L. Cushman

Sam W. West

William W. Dudley, Jr.

$$
161-2 / 67
$$

$$
\begin{gathered}
/ 51(?)-/ 57(?) \\
2 / 58-2 / 67 \\
2 / 56-2 / 67
\end{gathered}
$$

$2 / 67-8 / 6 \varepsilon$

$8 / 68-6 / 73$

$12 / 73-12 / 78$

$4 / 79$ - present 
Inquiries regarding projects described in this volume may be directed to the District office or Subdistrict office in which the work originated.

\author{
Wyoming District Office \\ U.S. Geological Survey \\ Water Resources Division \\ 2120 Capitol Avenue \\ P.0. Box 1125 \\ Cheyenne, WY 82001 \\ (307) 778-2220 ext. 2153
}

Subdistrict Offices

215 N. Lincoln Street

Casper, WY 82601

(307) 265-5550
1214 Big Horn Avenue

Worland, WY 82401

(307) 347-2181

Field Headquarters

381 N. Main

P.0. Box S

Buffalo, WY 82834

(307) 684-9661

509 S. Federal Blvd.

P.0. Box 431

Riverton, WY 82501

(307) 856-3771
489 East 5th South

P.0. Box 1175

Green River, WY 82935

(307) 875-6700

Field Unit

2120 Capitol Ave.

P.O. Box 1125

Cheyenne, WY 82001

(307) 778-2220 ext. 2153

Figure 1.--Location of offices in Wyoming.

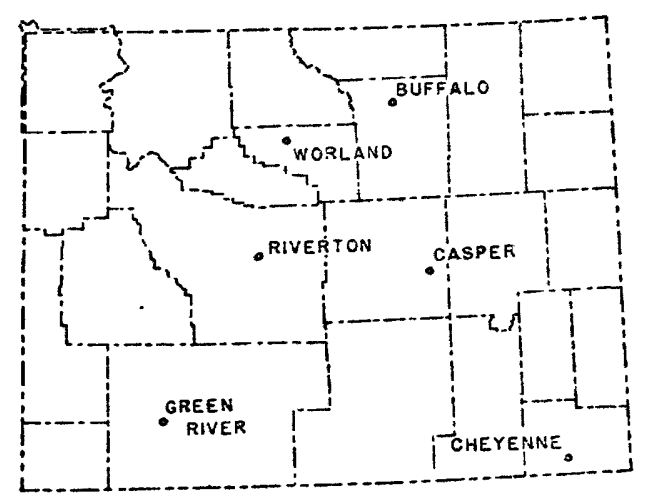




\section{WYOMING DISTRICT ORGANIZATION CHART}

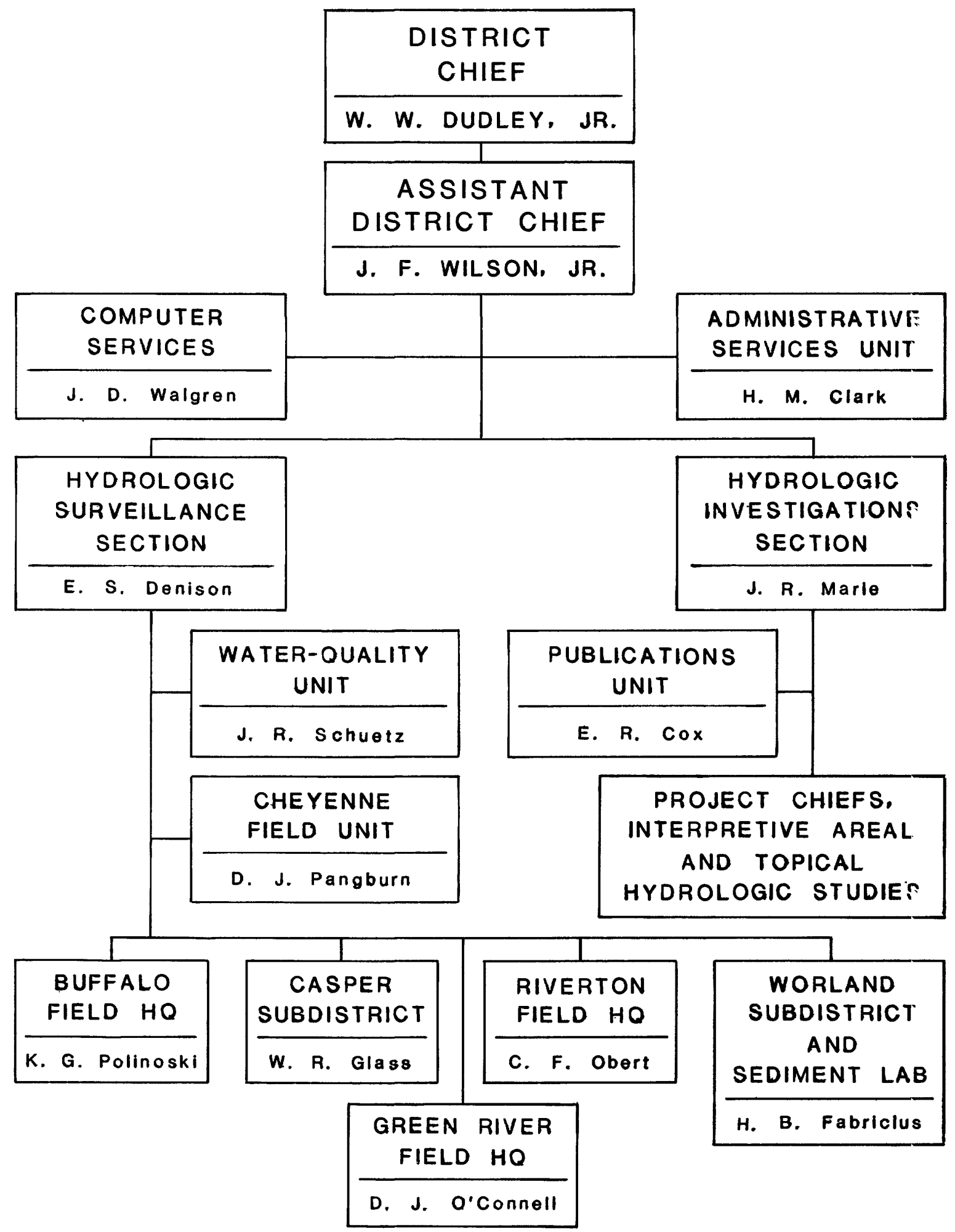

Figure 2. 
Current releases are described in a monthly pamphlet, "New Publications of the Geological Survey," which may be obtained from

$$
\begin{aligned}
& \text { Branch of Distribution } \\
& \text { U.S. Geological Survey } \\
& 1200 \text { South Eads Street } \\
& \text { Arlington, VA } 22202
\end{aligned}
$$

Professional Papers, Bulletins, Water Supply Papers, Techniques of Water Resources Investigations, Earthquake Information Bulletin, and popular leaflets, pamphlets, and booklets may be purchased from the above address. Additional information is given in "A Guide to Obtaining Information from the U.S. Geological Survey, 1978," Geological Survey Circular 777, available without cost from the above address.

Open-file reports from Wyoming are available for inspection at the Wyoming District office. Office.

Flood-prone area maps may be obtained from the Wyoming District

Map information is available from

$$
\begin{aligned}
& \text { Branch of Distribution } \\
& \text { U.S. Geological Survey } \\
& \text { Box 25286, Federal Center } \\
& \text { Lakewood, CO } 80225
\end{aligned}
$$

Requests for miscellaneous water information and information on programs in other States may be referred to

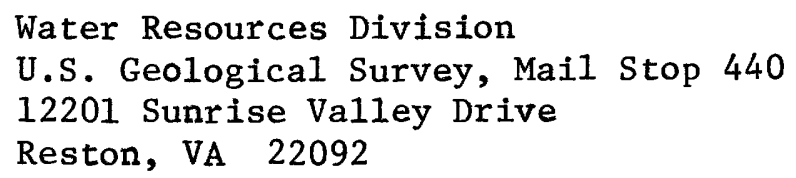

The Geological Survey National Center maintains a library with an extensive earth-sciences collection. Local libraries may obtain bool's, periodicals, and maps through interlibrary loan by writing to

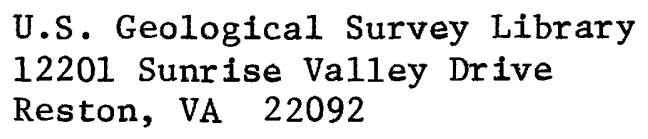




\section{DATA-COLLECTION SITES}

Lists of the data-collection sites and the kinds of hydrologic data being collected at each are given as follows: Table 1, surfacewater stations; table 2, ground-water stations; table 3, water-quality stations; table 4, sediment stations; and table 5, peak-flow partialrecord stations.

Identification numbers have been assigned to conform with the standard downstream order for listing stations within each hydrologic region. The location of each data site is given in the tables. In table 2, ground-water stations are listed in numerical order by counties.

The headings of the columns in the five tables are slightly different to accomodate the type of sites in each 1ist. In order to include the variety of information required by the many users of the lists, abbreviations and codes were used to conserve space in the tables. Explanations of the abbreviations and codes precede each table.

The locations of surface-water data sites are shown in figures 3-7. The locations of ground-water stations are shown in figures 8-11. 


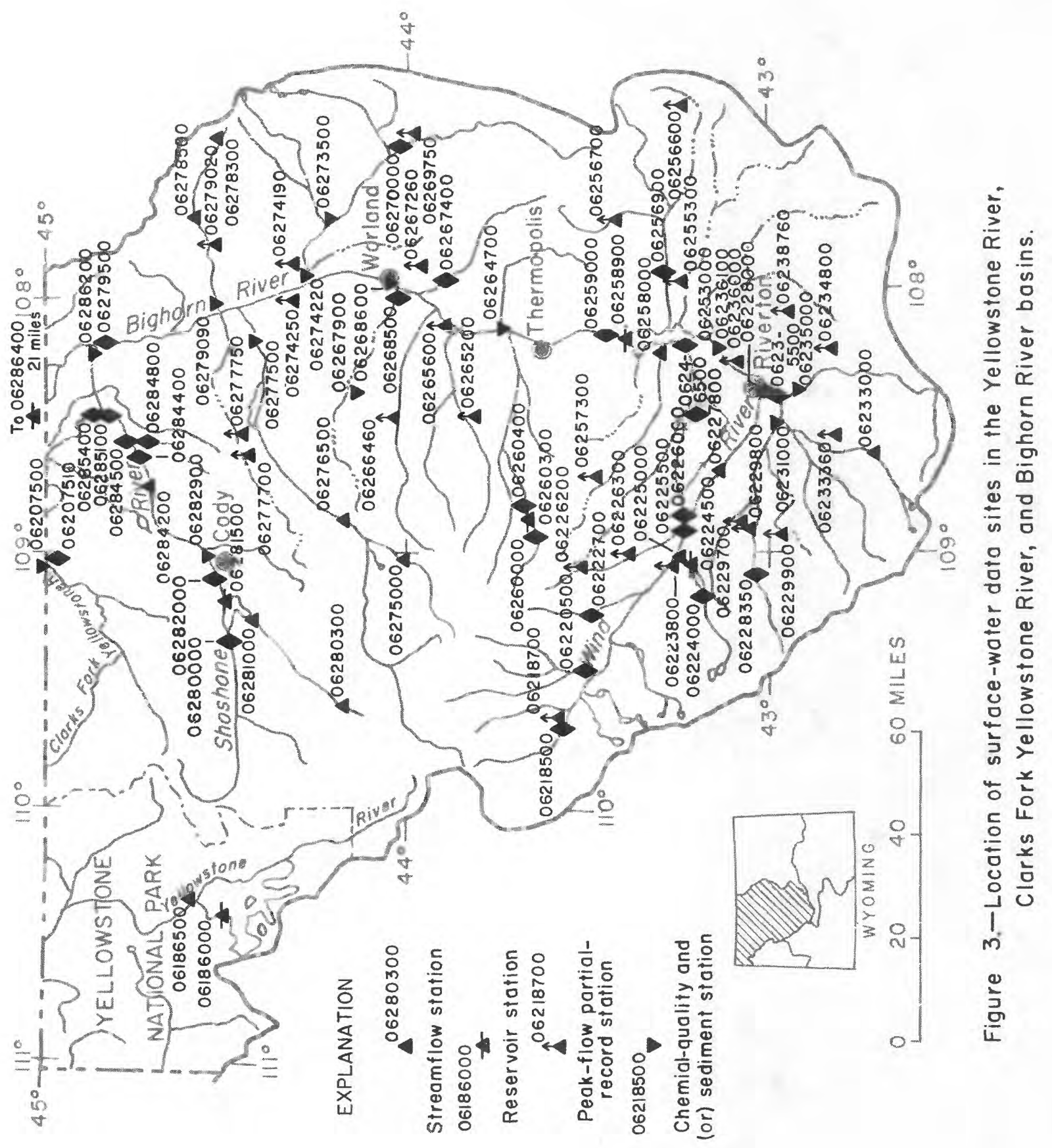




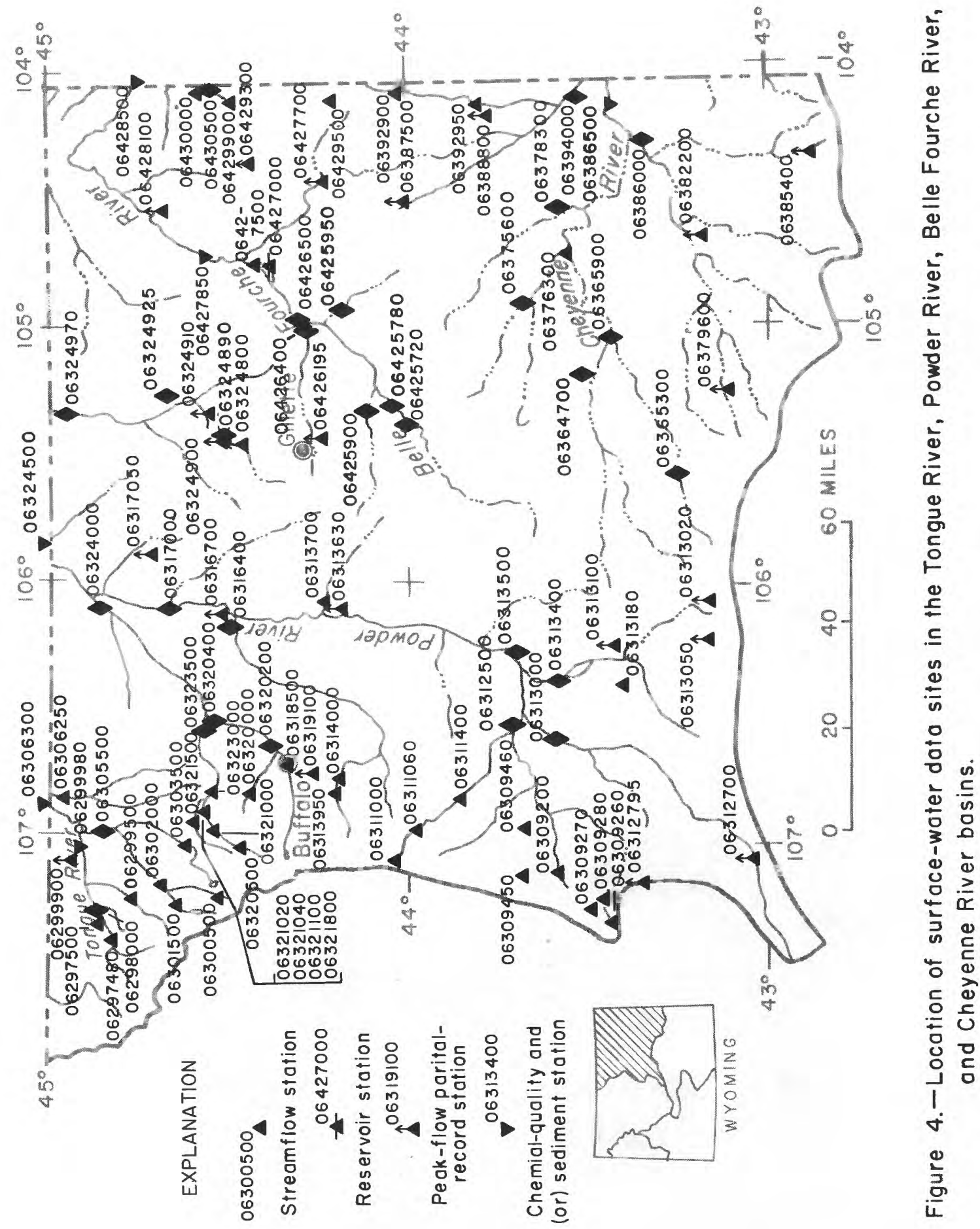




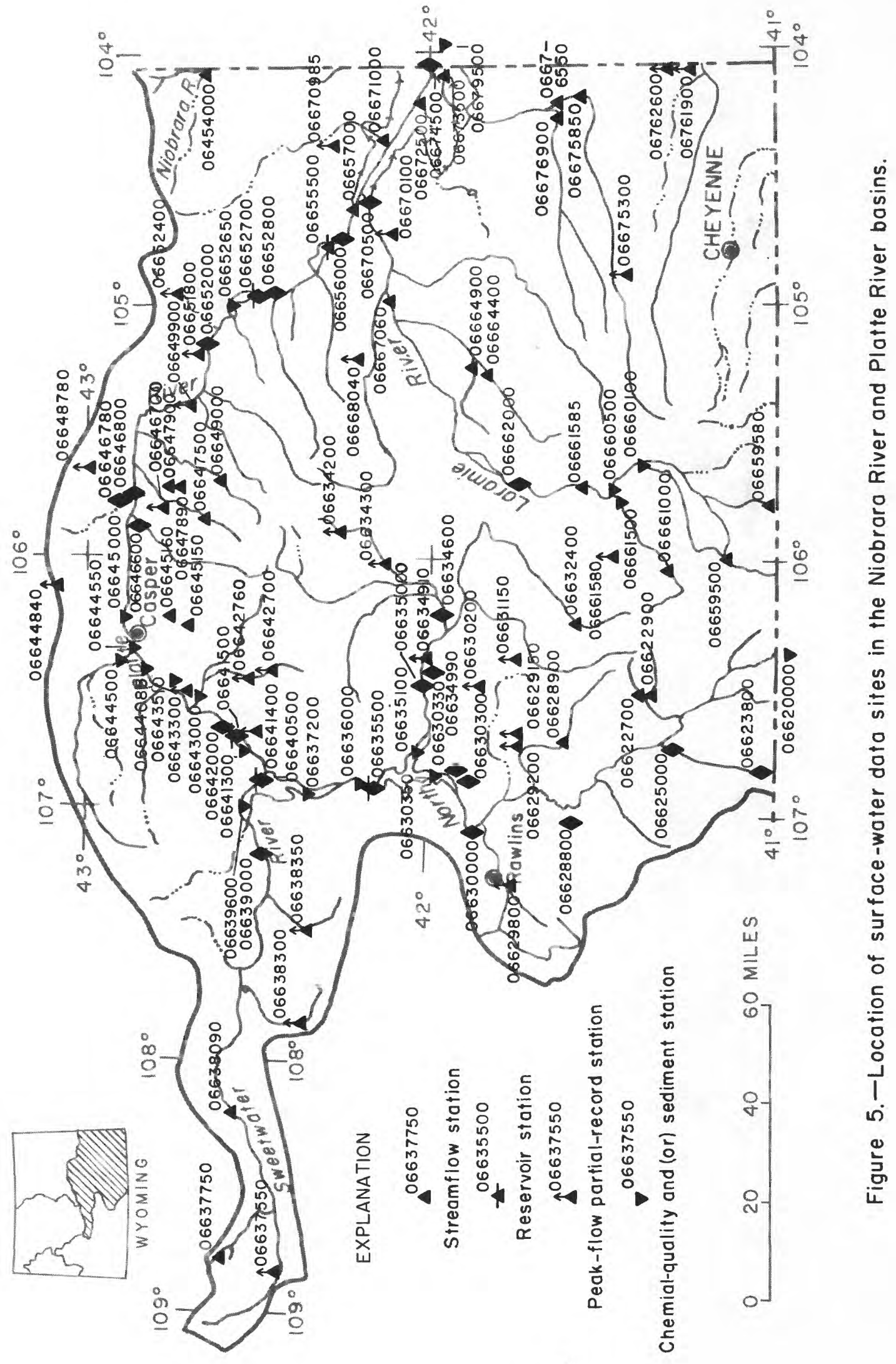




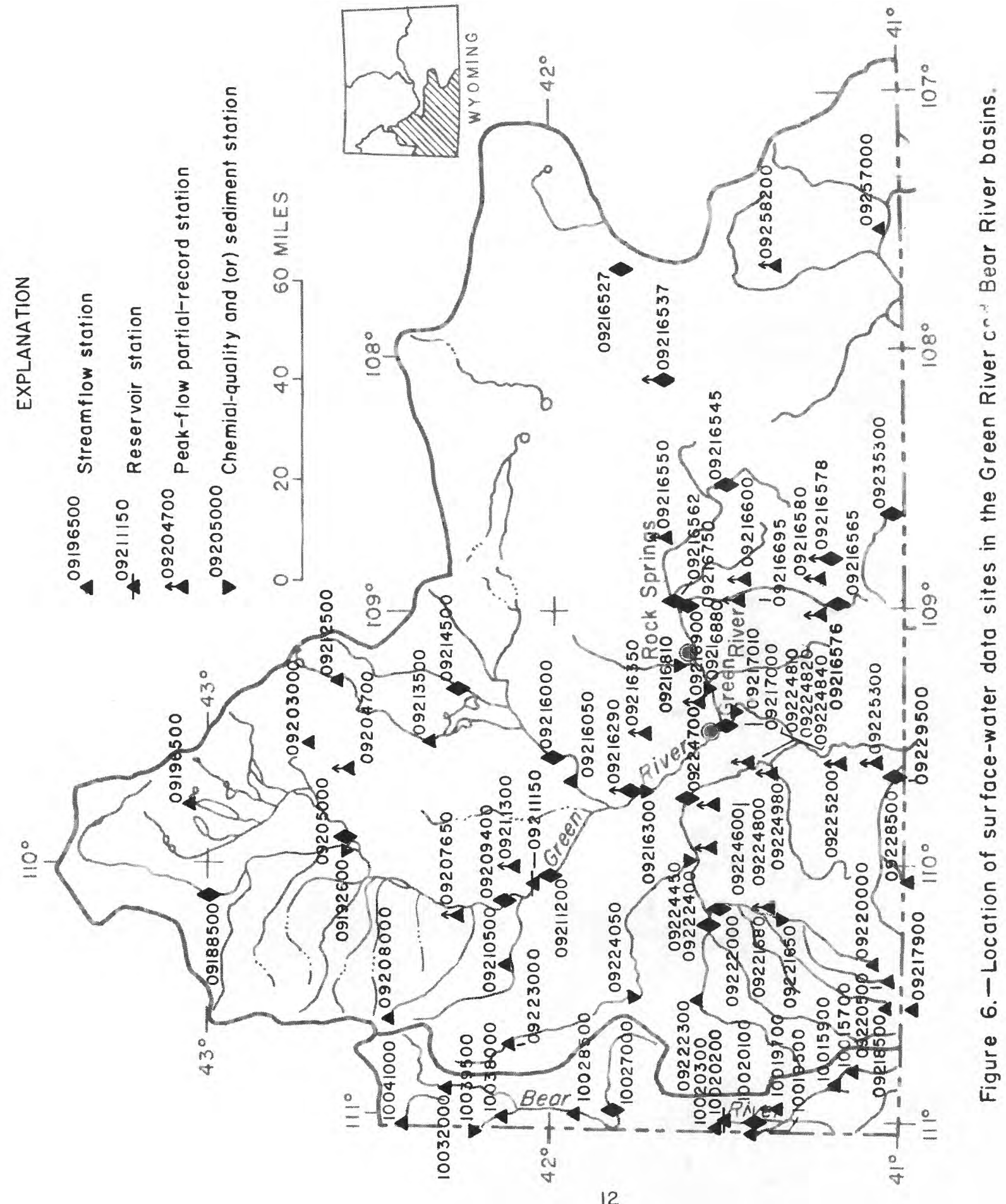




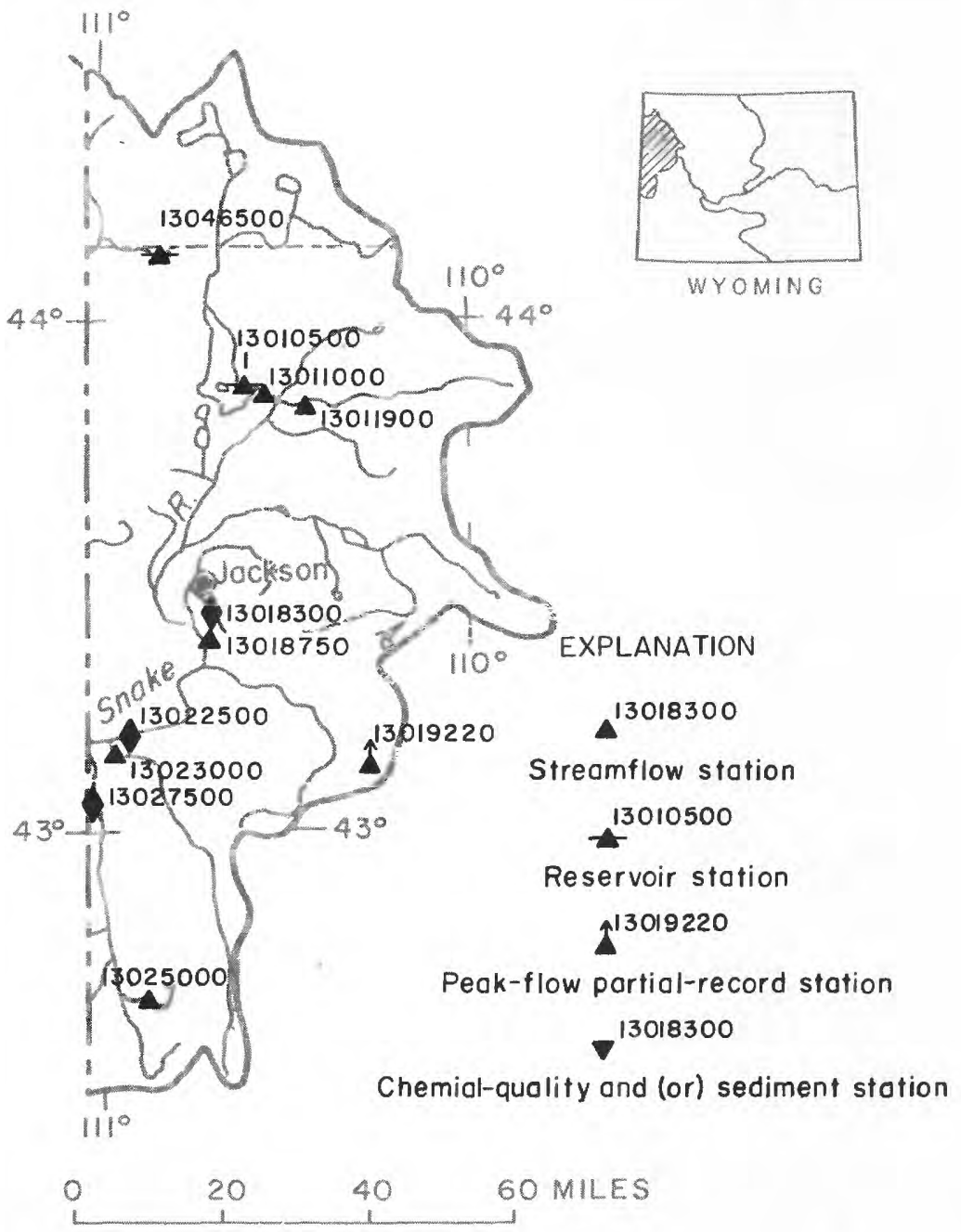

Figure 7.-Locotion of surfoce-water data sites in the Snake River basin. 
Surface-water stations 
Purpose: B, bench-mark or long-term-trend station

$C$, current-purpose station such as accounting, operation,

forecasting, disposal, water quality, compact or

legal, research or special study

$\mathrm{H}$, hydrologic station

P, principal-stream station

$R$, regulated station

Period of Record: The dates given are the calendar years in which records began or ended. Breaks of less than a year are not shown.

Location: SE, section

TSP, township

RNGE, range

Gage Equipment: D, digital recorder

G, graphic recorder

$M$, manometer gage

0 , observer record only

$S$, staff gage

$T$, pressure-transducer gage

$W$, well gage

Current Record Type: S, seasonal operation (no winter records)

$\mathrm{Y}$, full-year operation

\begin{tabular}{|c|c|}
\hline Leld of & $\begin{array}{l}\text { B, Buffalo } \\
\text { C, Casper } \\
\text { CF, Cheyenne Field Unit } \\
\text { CT, Contractor } \\
\text { GR, Green River } \\
\text { I, Idaho District } \\
\text { M, Montana District }\end{array}$ \\
\hline operator: & $\begin{array}{l}\text { BLM, Bureau of Land Management } \\
\text { BRUC, Bureau of Reclamation, Upper Colorado Region } \\
\text { BRUM, Bureau of Reclamation, Upper Missouri Region } \\
\text { CE, Corps of Engineers } \\
\text { DEPD, Wyoming Department of Economic Planning and } \\
\text { Development } \\
\text { MRB, Geological Survey, Missouri River Basin Program } \\
\text { USE, Utah State Engineer } \\
\text { USGS, Geological Survey, Federal Program } \\
\text { WDEQ, Wyoming Department of Environmental Quality } \\
\text { WGF, Wyoming Department of Game and Fish } \\
\text { WSE, Wyoming State Engineer }\end{array}$ \\
\hline
\end{tabular}

Remarks: USBR, U.S. Bureau of Reclamation 


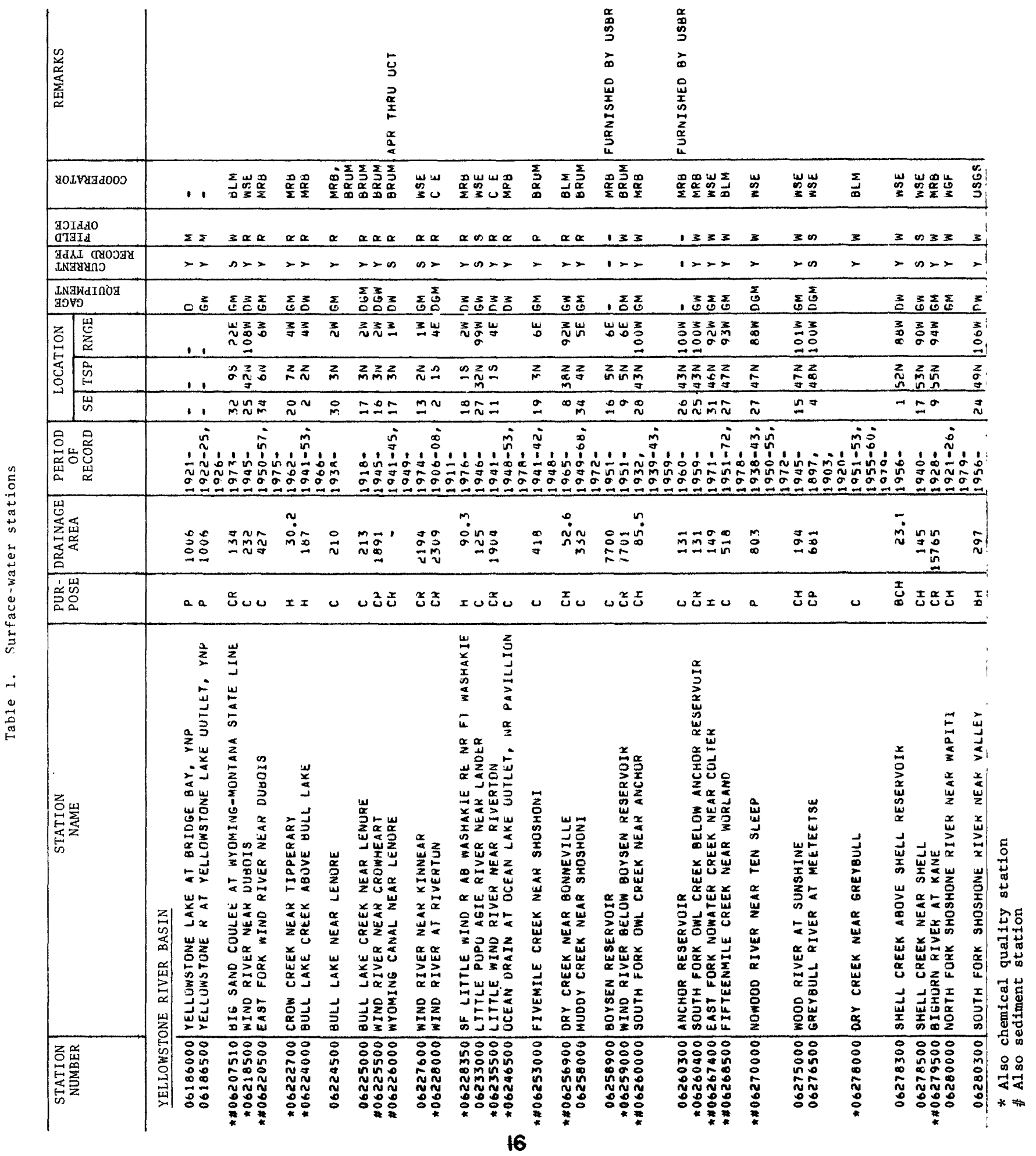




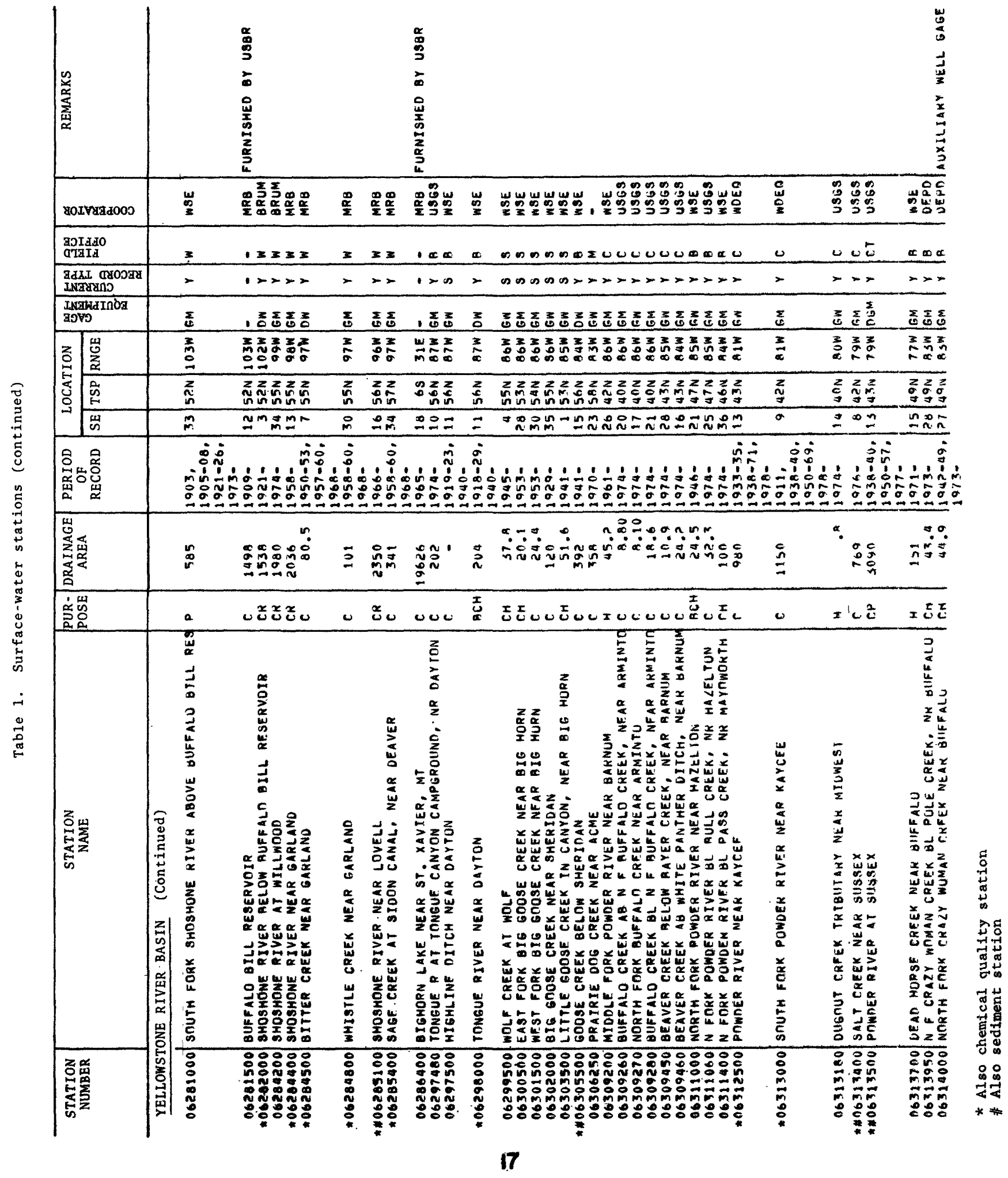




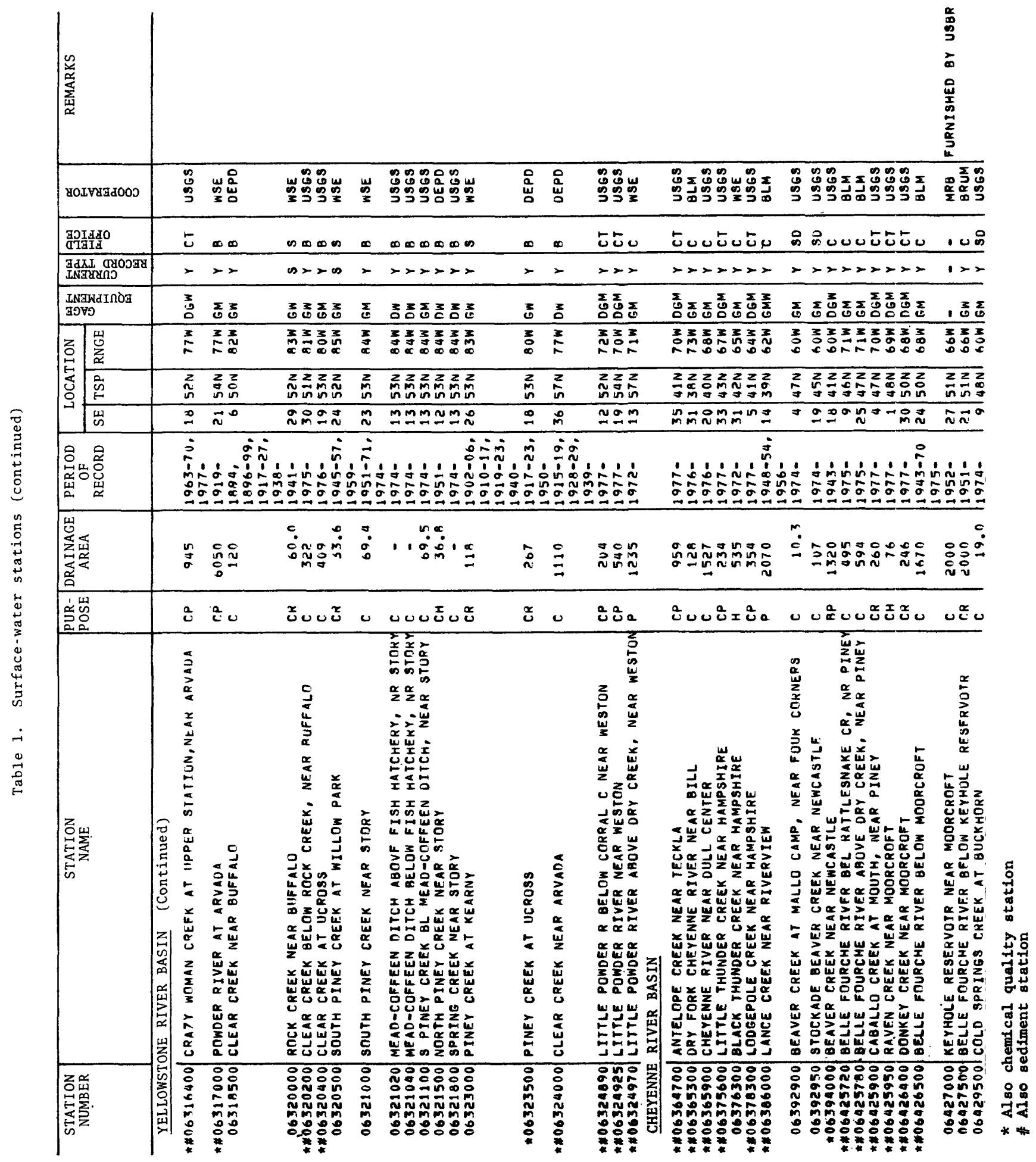




\begin{tabular}{|c|c|c|c|c|c|c|c|c|c|c|}
\hline & & & & & & 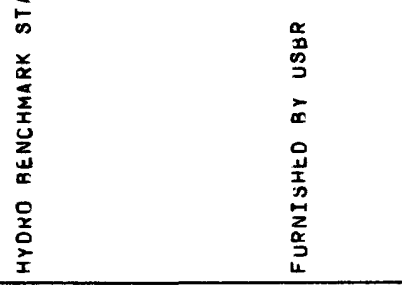 & 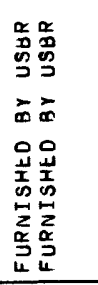 & & & 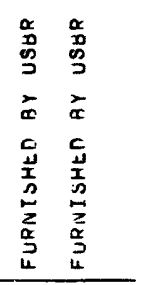 \\
\hline yoIVAGdoos & & 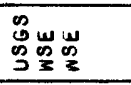 & & 1 & 崖岕 & 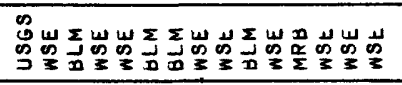 & 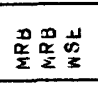 & $\begin{array}{ll}0 & 0 \\
0\end{array}$ & 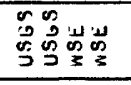 & 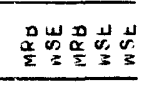 \\
\hline $\begin{array}{l}\text { ajIago } \\
\text { aTaIa }\end{array}$ & & ๑ัตัด & & 2 & ث̋ & 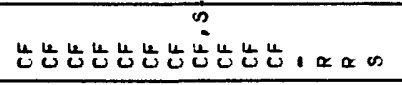 & .10 & 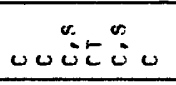 & 0000 & 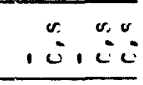 \\
\hline 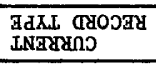 & & $>->$ & & $>$ & $\rightarrow \infty$ & $x>\infty>>>x>x+x-\infty$ & 112 & $x+x>x$ & $x+\infty x$ & 12120 \\
\hline 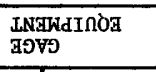 & & 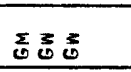 & & $\underline{z}$ & 홍 & 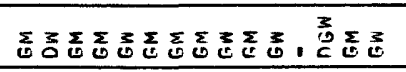 & $\ldots$ & 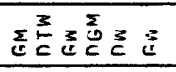 & 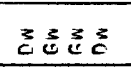 & . \\
\hline z岕 & & 要告世 & & $\begin{array}{l}3 \\
3 \\
0\end{array}$ & $\frac{3}{x} \frac{3}{\infty}$ & 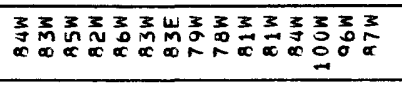 & 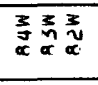 & 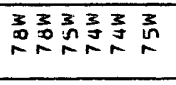 & 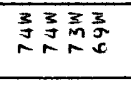 & 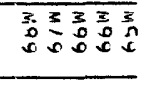 \\
\hline 宏商 & & $\sum_{n} \geq z$ & & $\frac{2}{m}$ & 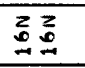 & 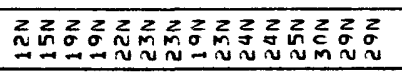 & 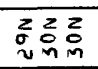 & 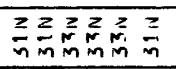 & 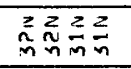 & 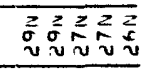 \\
\hline$\sqrt[4]{n}$ & & $\operatorname{nn} \infty$ & & 2 & ${ }^{\infty} i$ & 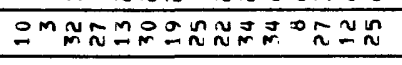 & शः̃ & 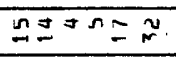 & $\cos =$ & onำ \\
\hline 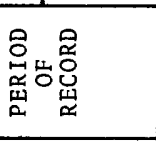 & & 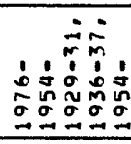 & & $\begin{array}{l}\stackrel{1}{n} \\
\stackrel{n}{\sigma} \\
-\end{array}$ & 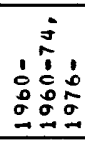 & 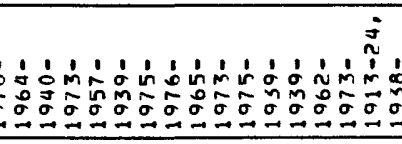 & & 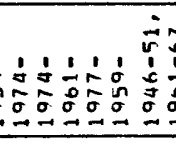 & 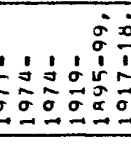 & 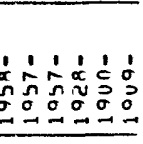 \\
\hline 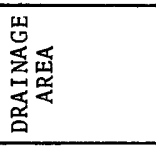 & & $\hat{n} \cdot \bar{T}$ & & in & $\stackrel{\dot{0}}{\dot{m}} \underset{\mathrm{i}}{\mathrm{i}}$ & 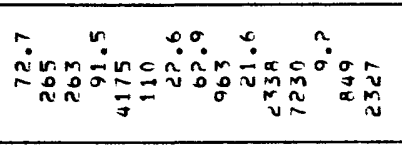 & 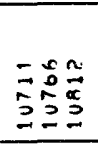 & $-\frac{n}{2}$ & 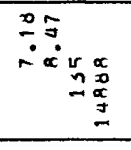 & \\
\hline 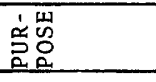 & & טuI & & $\begin{array}{l}I \\
\\
\end{array}$ & \pm 0 & 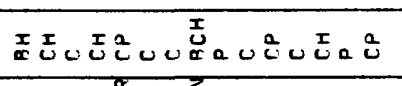 & $\cos$ & 山心忈忈I & $\operatorname{cax}$ & c. c.ec $e^{x} e^{x}$ \\
\hline 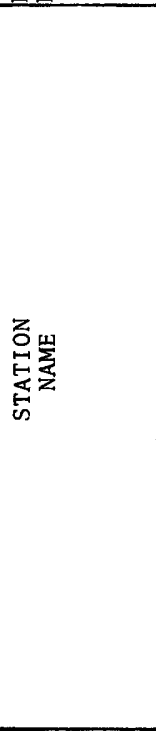 & 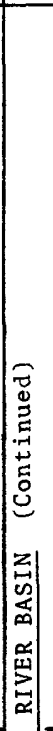 & 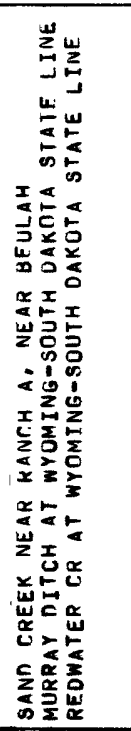 & 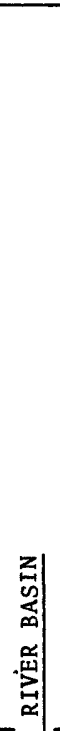 & 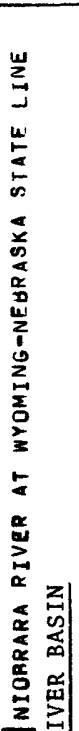 & 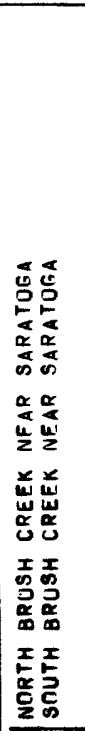 & 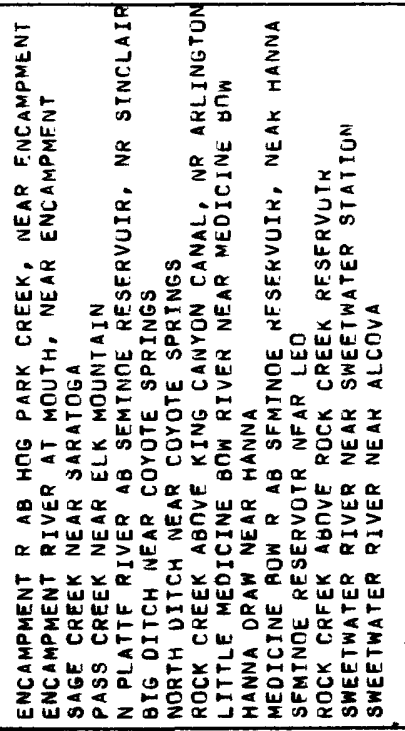 & 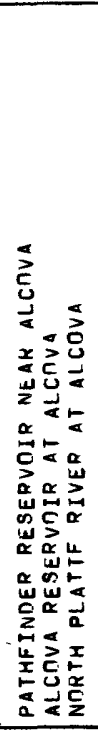 & 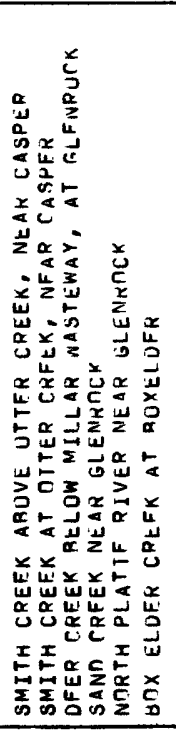 & 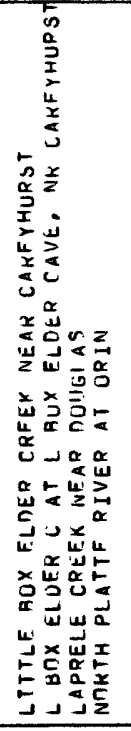 & 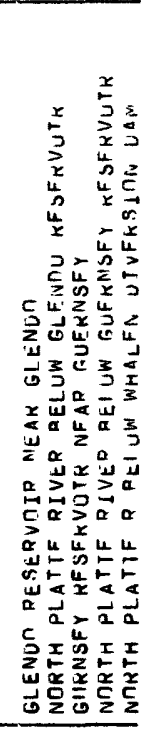 \\
\hline 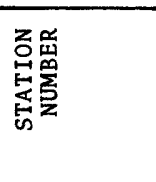 & 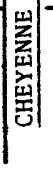 & 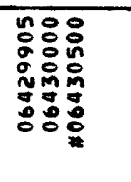 & 趁 & 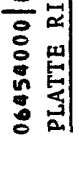 & 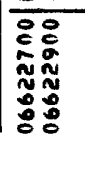 & 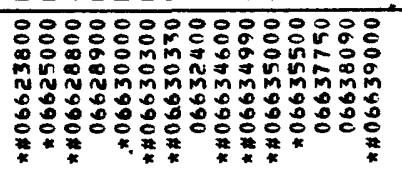 & 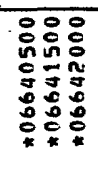 & 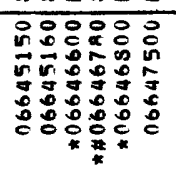 & 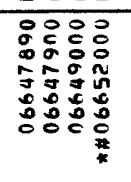 & 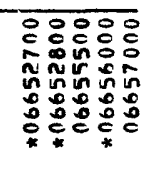 \\
\hline
\end{tabular}




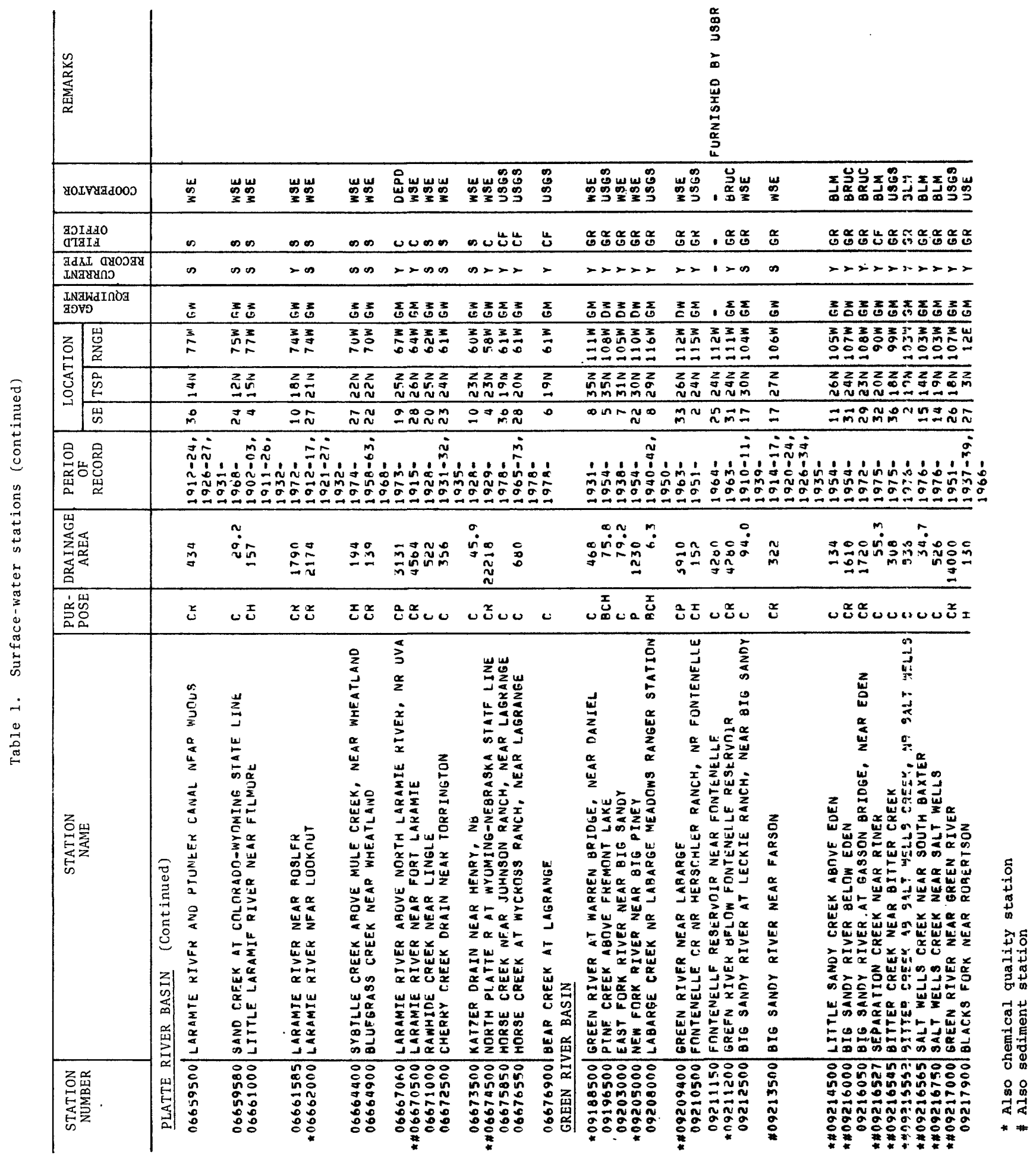




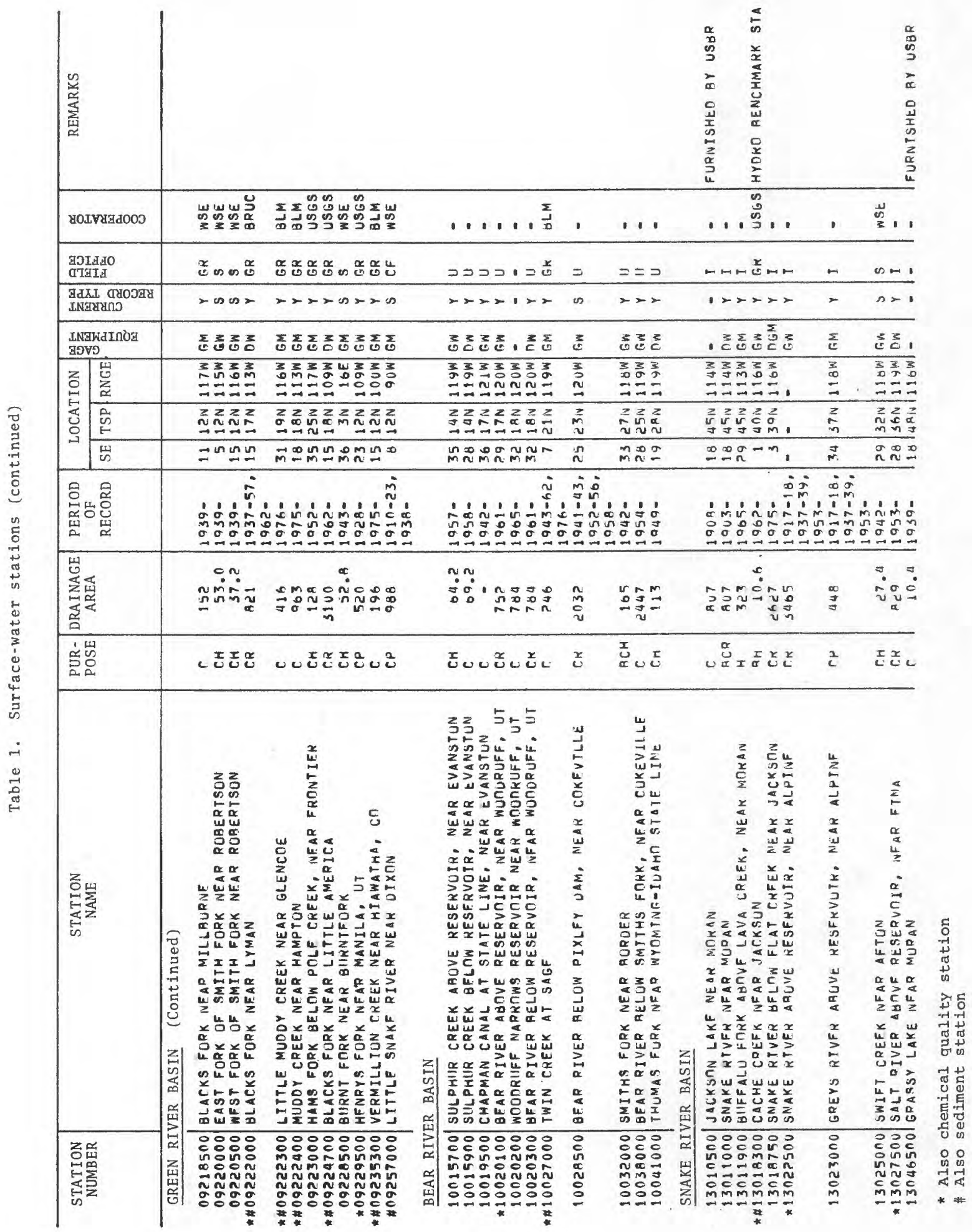




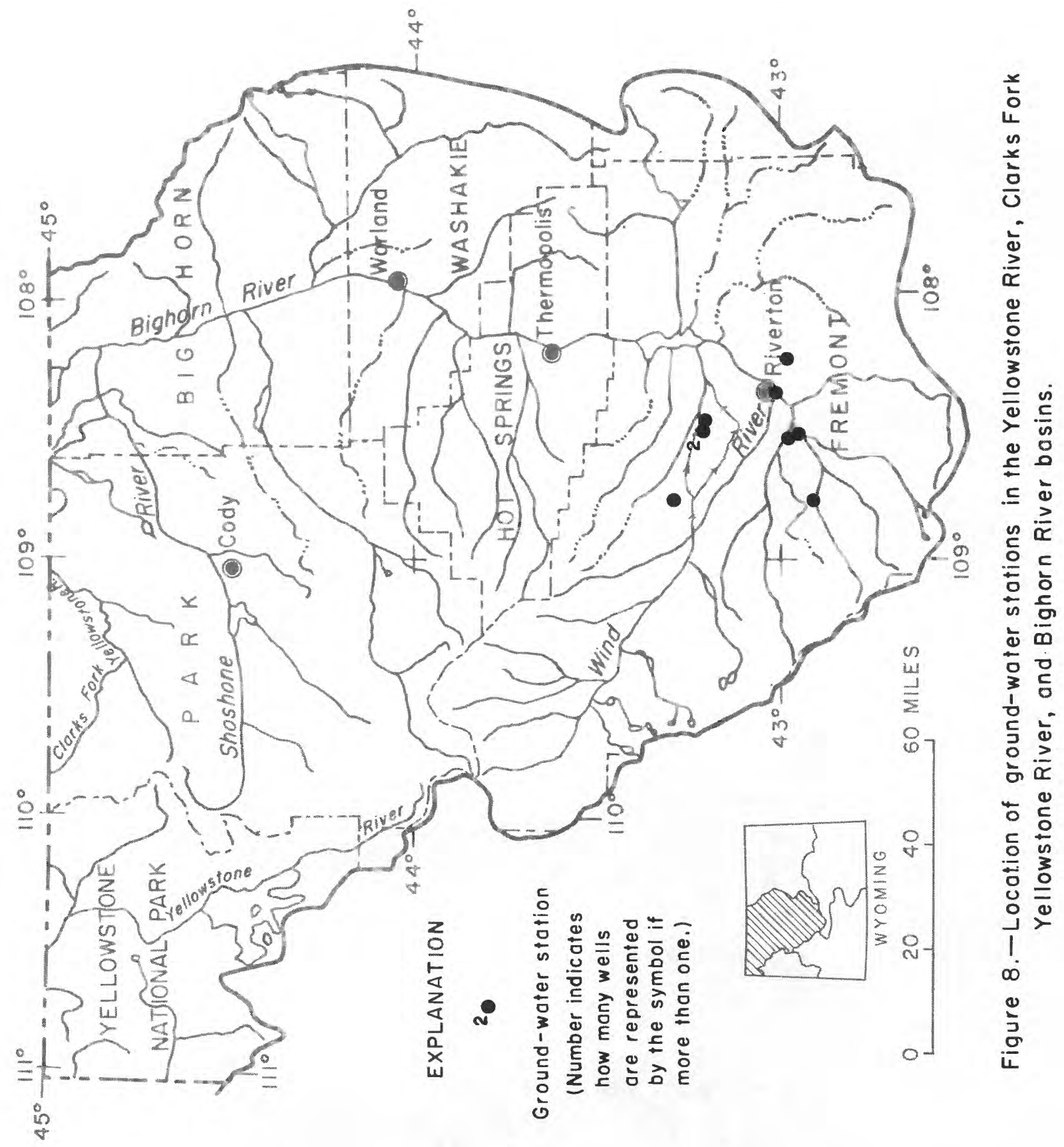




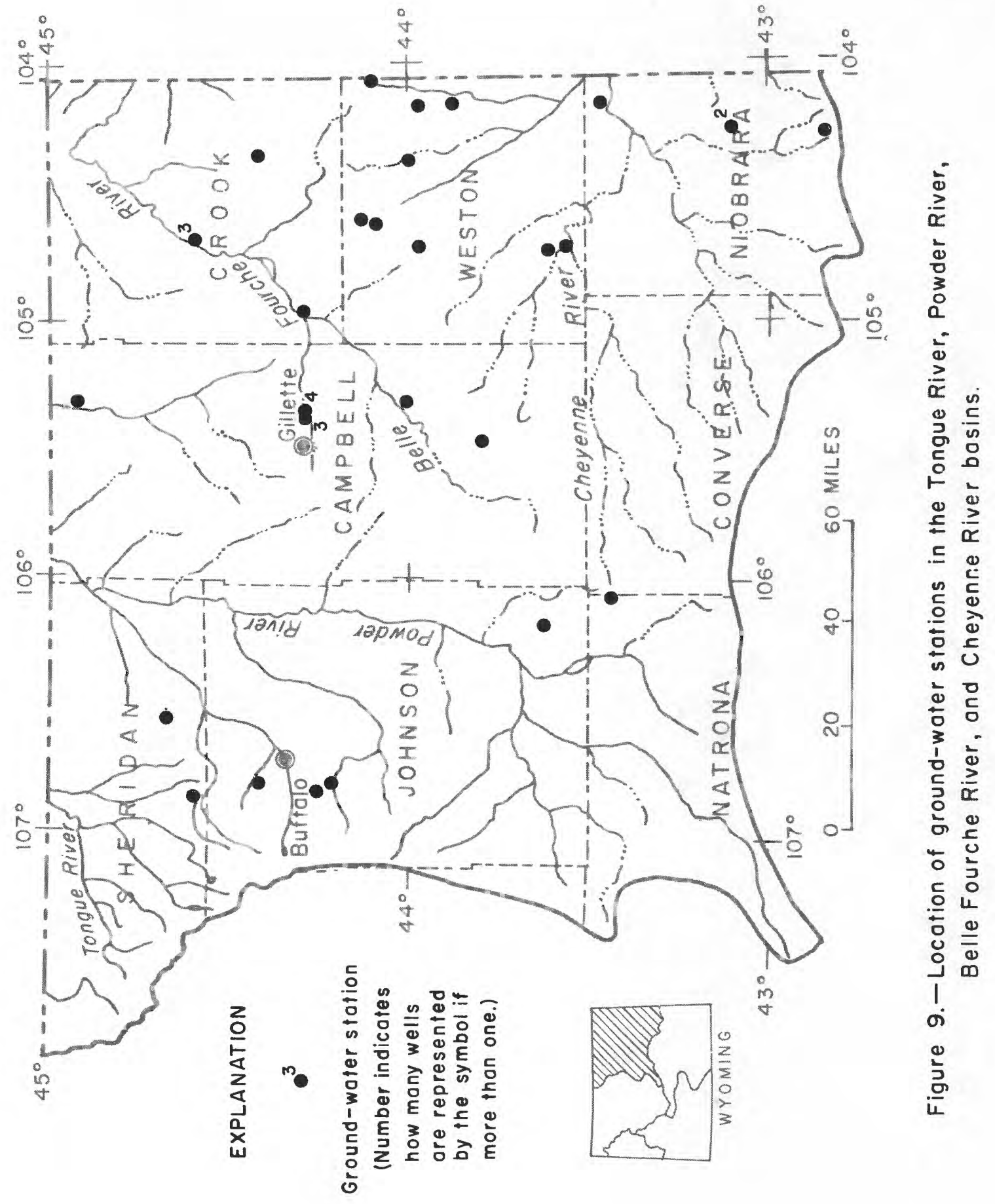




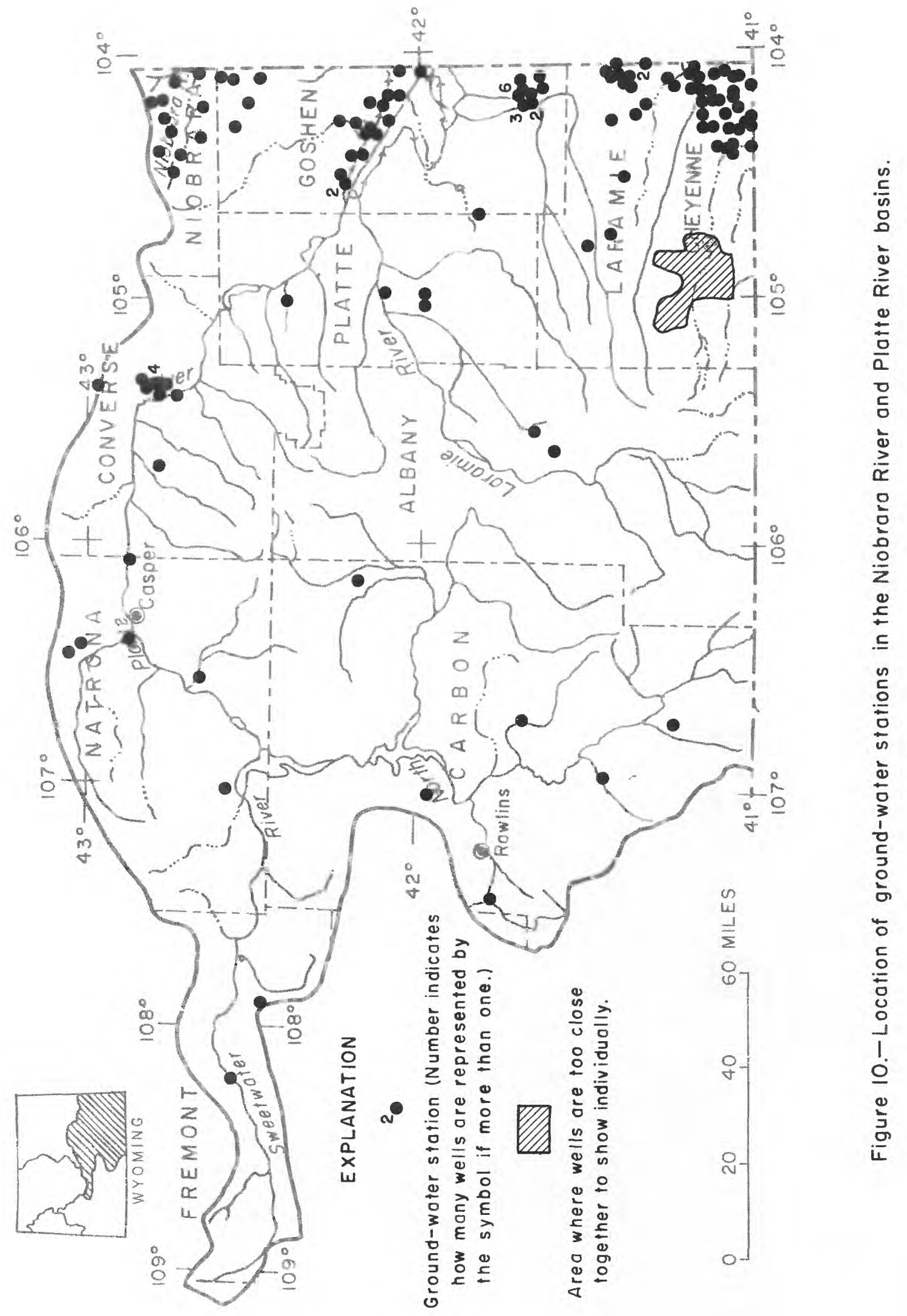



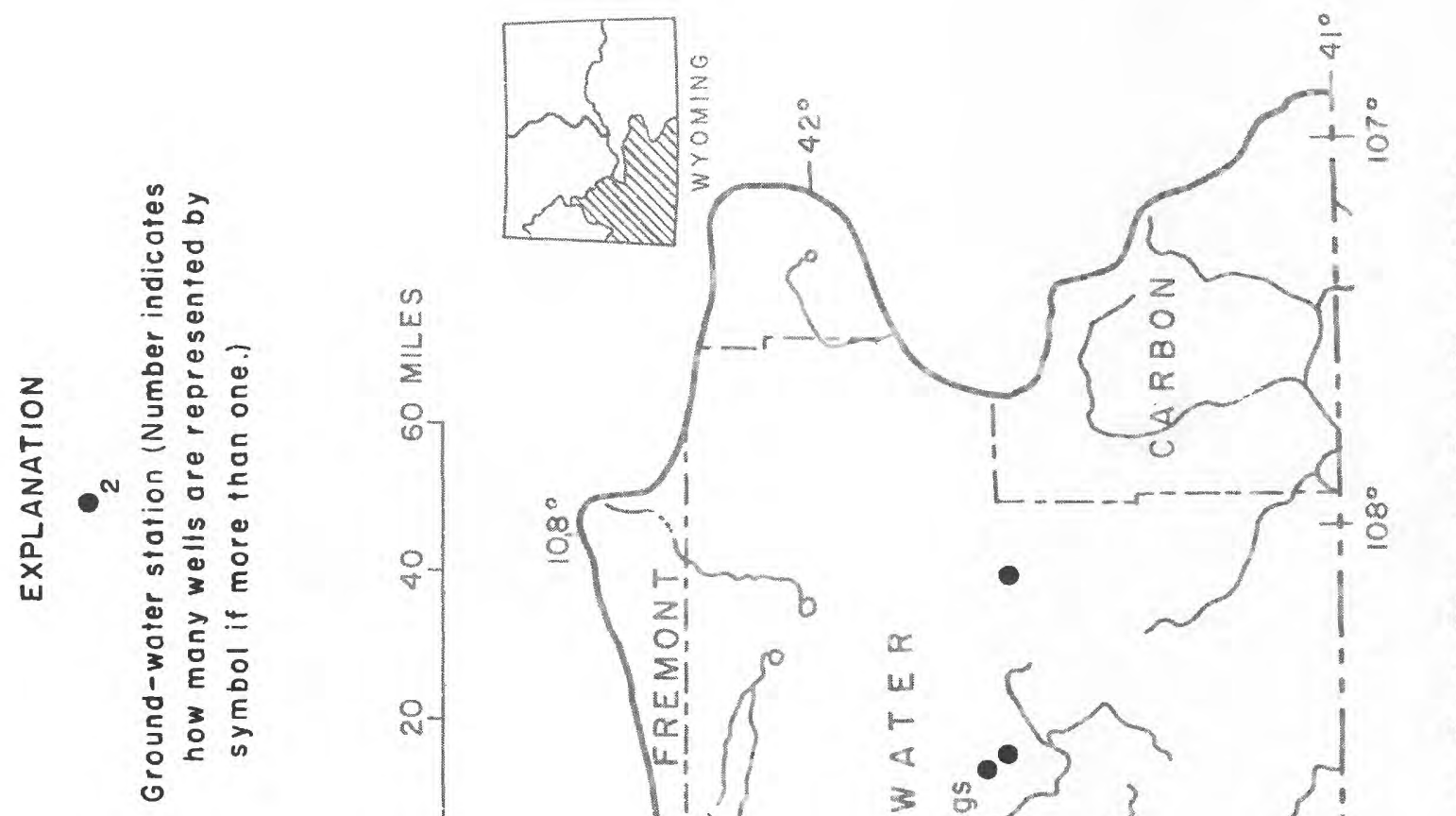

(2)

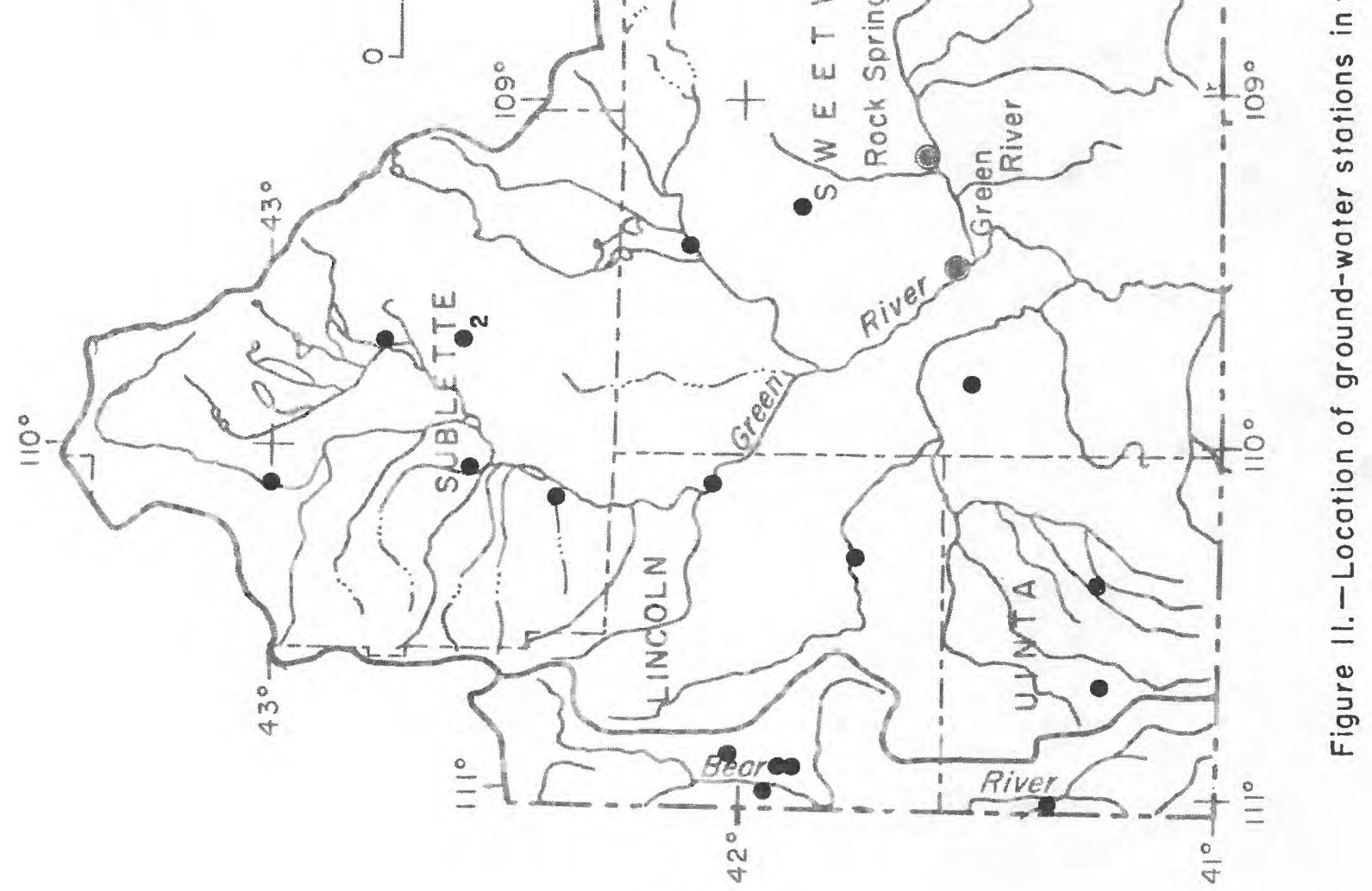


Ground-water stations 
Explanation of abbreviations and codes used in table 2 .

We11 number: The well-numbering procedure used is based on the U.S. Land Grant System. The first segment of the number is the township (north); the second number segment is the range (west); the third number segment is the section, which is followed by a first letter designating the quarter section, a second letter, if shown, designating

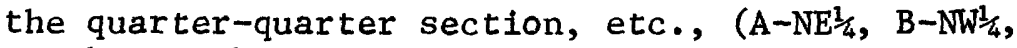
$\left.\mathrm{C}-\mathrm{SW} \frac{1}{4}, \mathrm{D}-\mathrm{SE} \frac{1}{4}\right)$. We11 30-108-05BCD2, for examp1e, is in

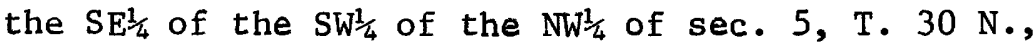
$\mathrm{R}$. $108 \mathrm{~W}$. The number 2 indicates it is the second well in the quarter-quarter-quarter section. Wells shown in Fremont County have an additional uppercase letter that begins the number. This letter designates the quadrant of the Wind River Meridian and Base Line System. The quadrants are lettered $A, B, C$, and $D$ in a counter-clockwise direction beginning with $A$ in the northeast quadrant.

Lat-Long-Seq No.: The first six digits are the latitude in degrees, minutes, and seconds. The next seven digits are the longitude in degrees, minutes, and seconds. The last two digits indicate the sequence number of when the well was inventoried in the event more than one well has the same latitude and longitude. 
Explanation of abbreviations and codes used in table 2--continued Geologic Unit:

111 ALVM Alluvium

111 TRRC Terrace deposits

121 NRPK North Park Formation

121 OGLL Ogallala Formation

122 ARKR Arikaree Formation

123 BRUL Brule Formation

123 WRVR White River Formation or Group

124 LNEY Laney Shale Member of Green River Formation

124 WDRV Wind River Formation

124 WSTC Wasatch Formation

125 FRUN Fort Union Formation

211 ALMD Almond Formation

211 FXHL Fox Hills Sandstone
211 LNCE Lance Formation

211 MVRD Mesaverde Formation or Group

211 STEL Steele Shale

217 LKOT Lakota Formation

221 SNDC Sundance Formation

237 SPRF Spearfish Formation

317 FRLL Forelle Limestone Member of Goose Egg Formation

317 MNKT Minnekahta Limestone

331 MDSN Madison Limestone

337 PHSP Pahasapa Limestone

374 FLTD Flathead Quartzite or Sandstone

The seven-character geologic unit code given above consists of two parts. The first three characters are numeric and identify the Era, System, and Serles of the rock unit. The next four characters are in alpha mnemonic code for the name of the rock-stratigraphic unit.

Numeric Codes for Geologic Age Identification

$\begin{array}{cccc} & \text { Code } & & \text { Code } \\ \text { Cenozoic } & 100 & \text { Paleozoic--continued } & \\ \text { Quaternary } & 110 & \text { Pennsylvanian } & 320 \\ \text { Holocene } & 111 & \text { Upper } & 321 \\ \text { Pleistocene } & 112 & \text { Middle } & 324 \\ \text { Tertiary } & 120 & \text { Lower } & 327 \\ \text { Pliocene } & 121 & \text { Mississippian } & 330 \\ \text { Miocene } & 122 & \text { Upper } & 331 \\ \text { Ollgocene } & 123 & \text { Lower } & 337 \\ \text { Eocene } & 124 & \text { Devonian } & 340 \\ \text { Paleocene } & 125 & \text { Upper } & 341 \\ \text { Mesozoic } & 200 & \text { Middle } & 344 \\ \text { Cretaceous } & 210 & \text { Lower } & 347 \\ \text { Upper } & 211 & \text { Silurian } & 350 \\ \text { Lower } & 217 & \text { Upper } & 351 \\ \text { Jurassic } & \text { Middle } & 354 \\ \text { Upper } & 220 & \text { Lower } & 357 \\ \text { Middle } & 221 & \text { Ordovician } & 360 \\ \text { Lower } & 224 & \text { Upper } & 361 \\ \text { Triassic } & 227 & \text { Middle } & 364 \\ \text { Upper } & 230 & \text { Lower } & 367 \\ \text { Middle } & 231 & \text { Cambrian } & 370 \\ \text { Lower } & 234 & \text { Upper } & 371 \\ \text { Paleozoic } & 237 & \text { Middle } & 374 \\ \text { Permian } & 300 & \text { Lower } & 377 \\ \text { Upper } & 310 & \text { Precambrian } & 400 \\ \text { Lower } & 311 & & \end{array}$


Explanation of abbreviations and codes used in table 2--continued

Cooperator: CHEY, City of Cheyenne

USGS, Geological Survey, Federal Program

WSE, Wyoming State Engineer

Field office: B, Buffalo

C, Casper

$\mathrm{CF}$, Cheyenne Field Unit

$\mathrm{CH}$, Cheyenne Hydrologic Survelllance Section

GR, Green River

0 , Observer

P, Project Personnel

R, Riverton

$\mathrm{SD}$, South Dakota District

Frequency of Observation:

$C$, continuous (graphic or digital recorder)

$M$, monthly (12 visits per year)

$Q$, quarterly ( 4 visits per year)

$\mathrm{SA}$, semiannual (2 visits per year)

$A$, annual ( 1 visit per year)

$I$, infrequent or as required

Period of Record: The dates given are the calendar years in which records began or ended. A record consists of one or more measurements during a calendar year.

Remarks: Recorder 77- indicates recorder continuous to present. 


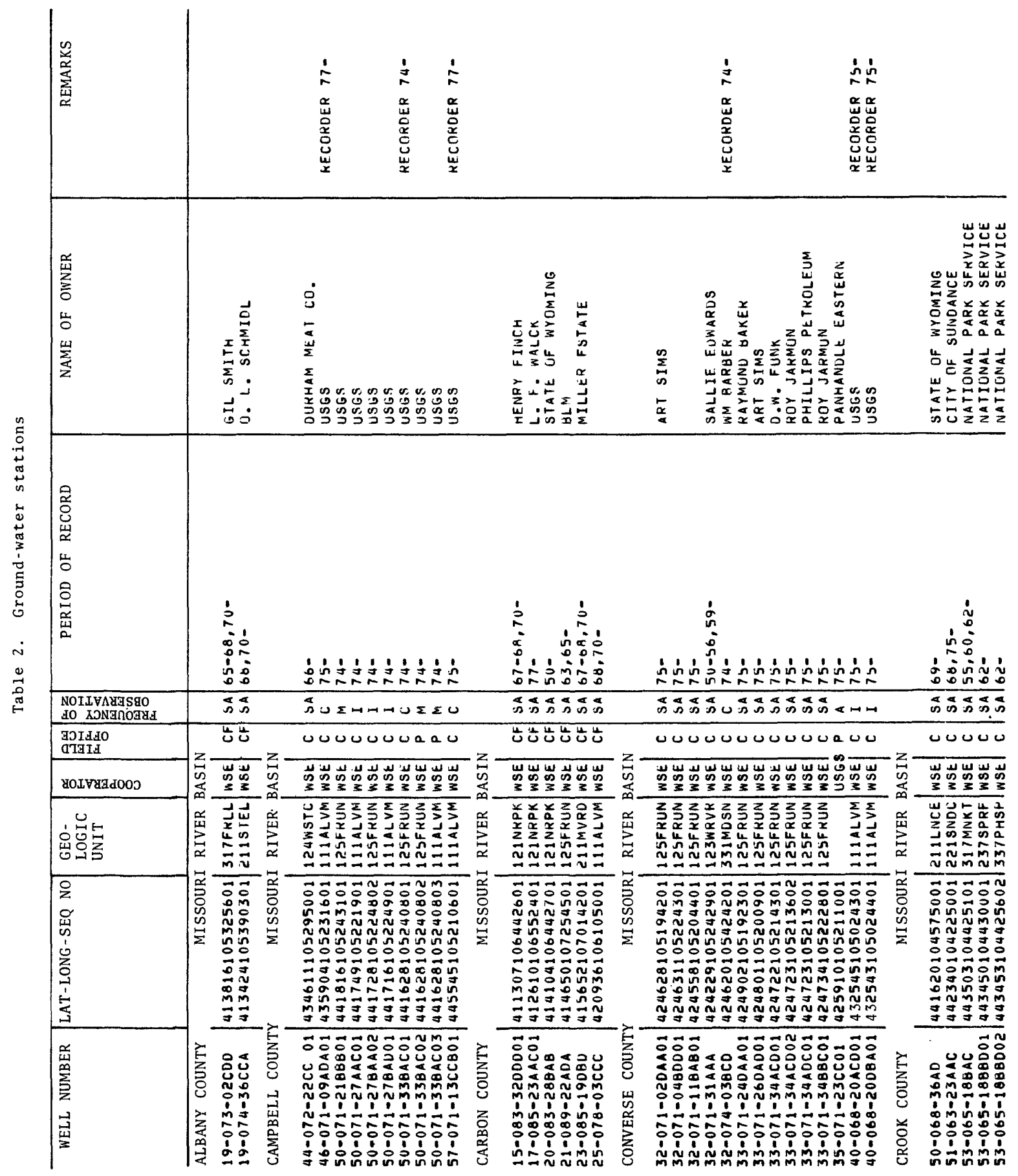




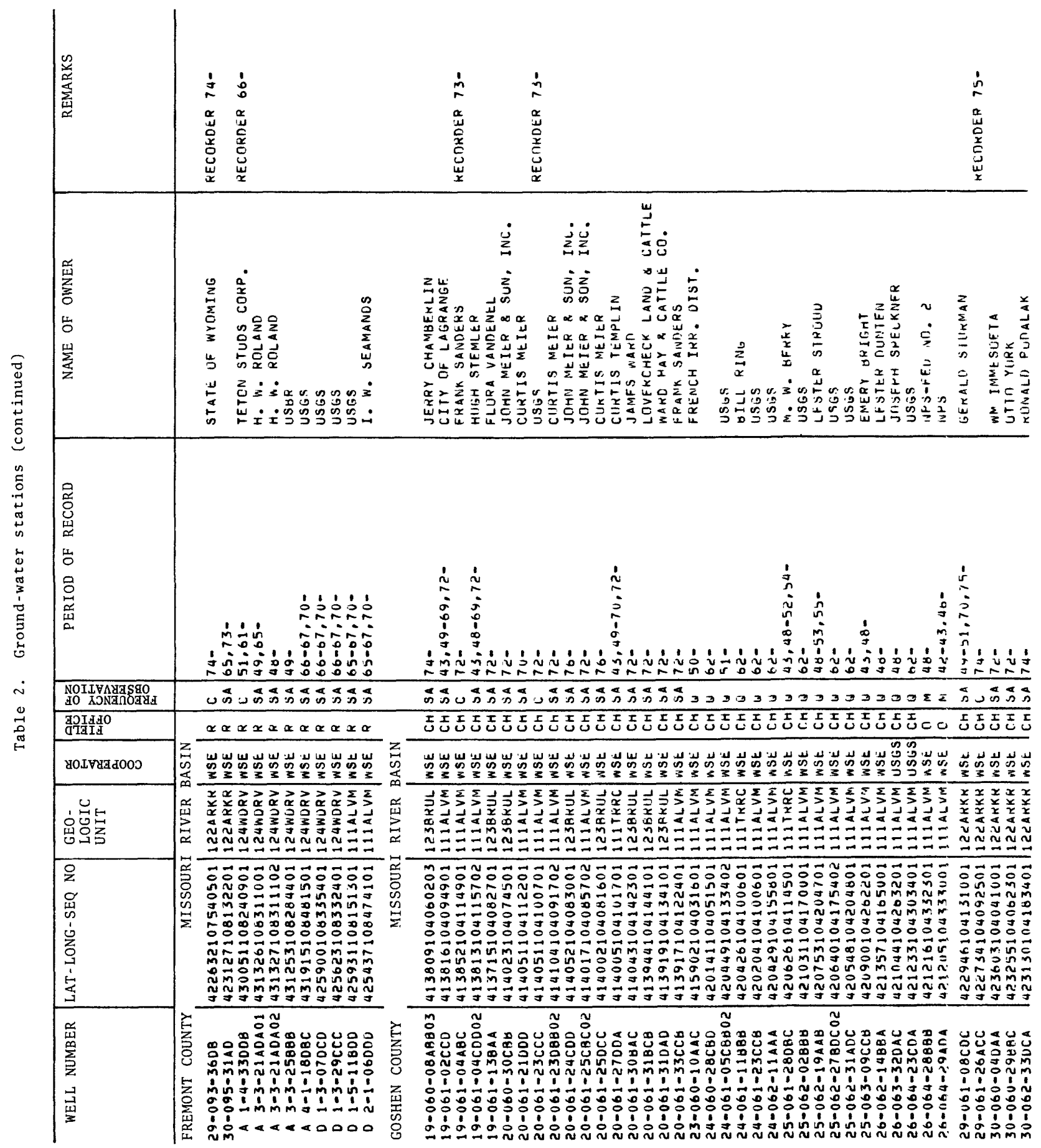




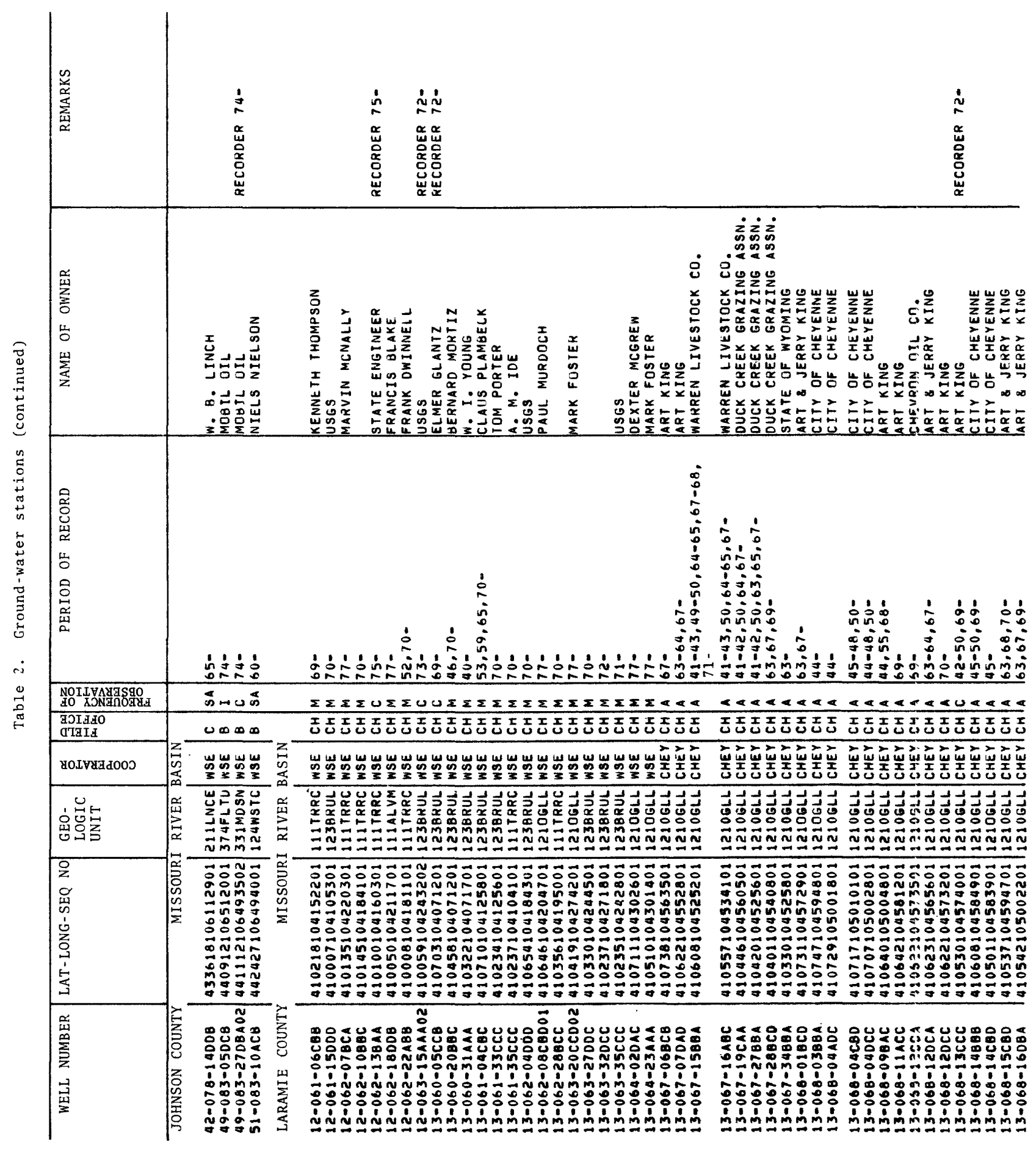




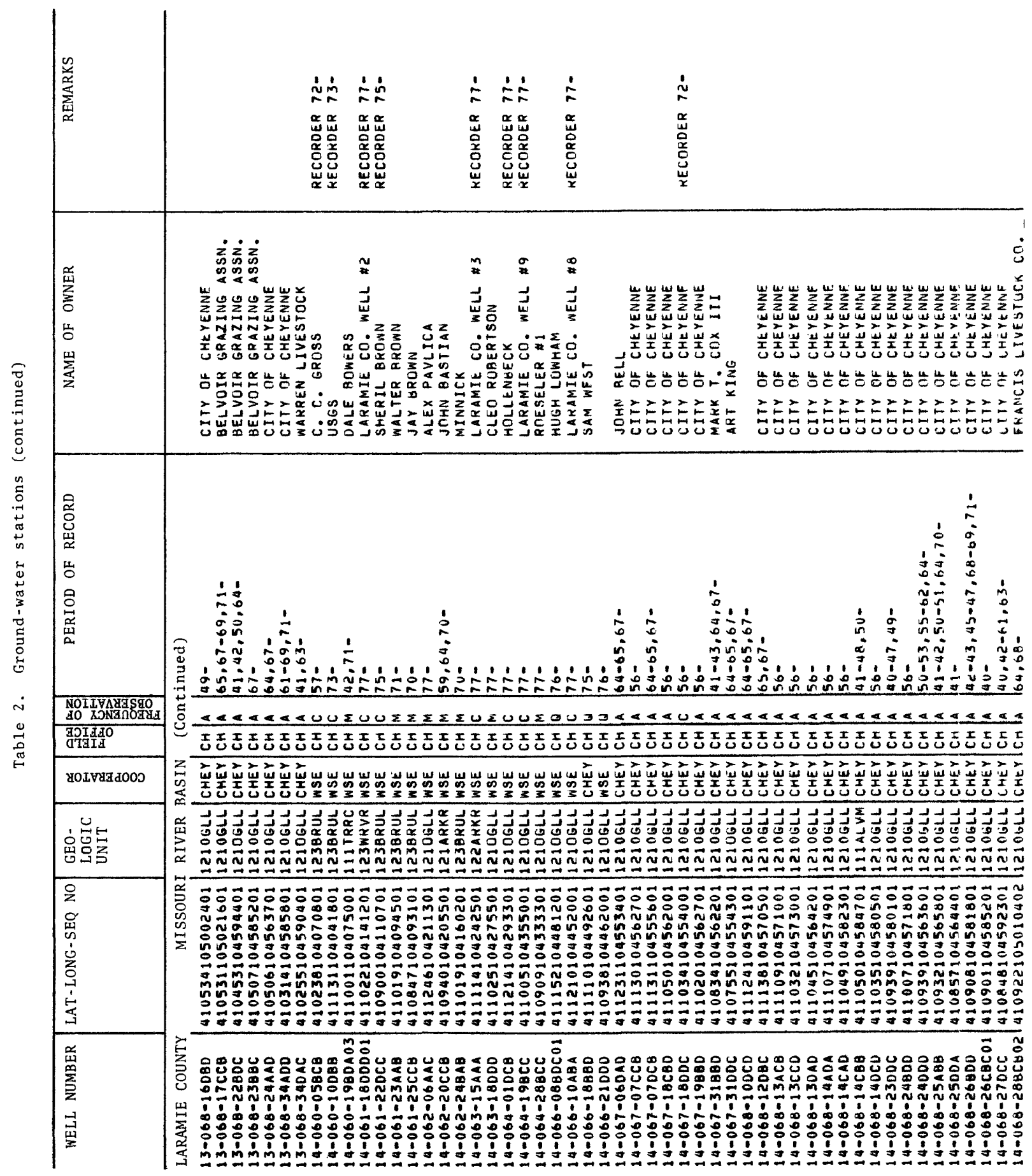




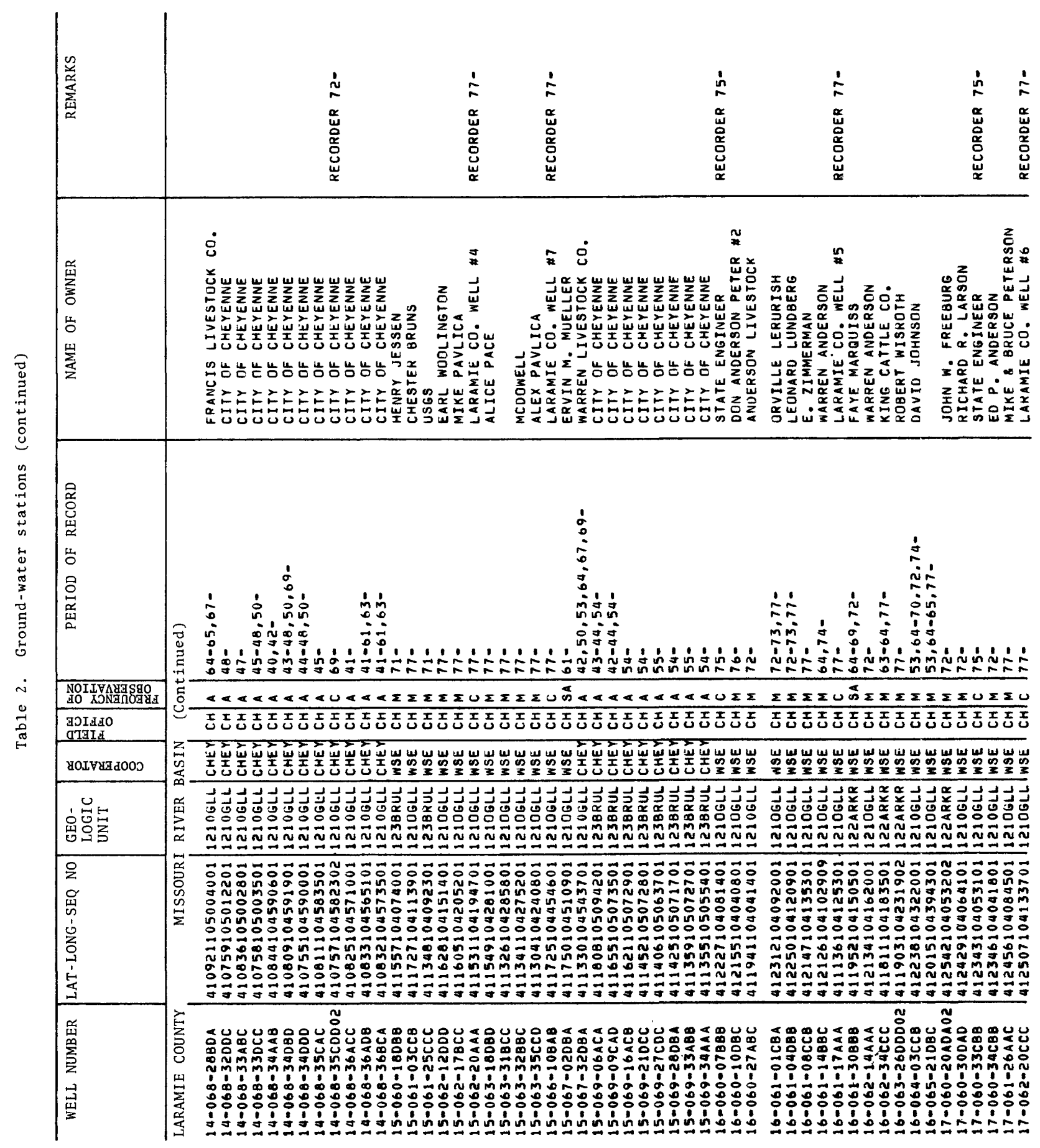




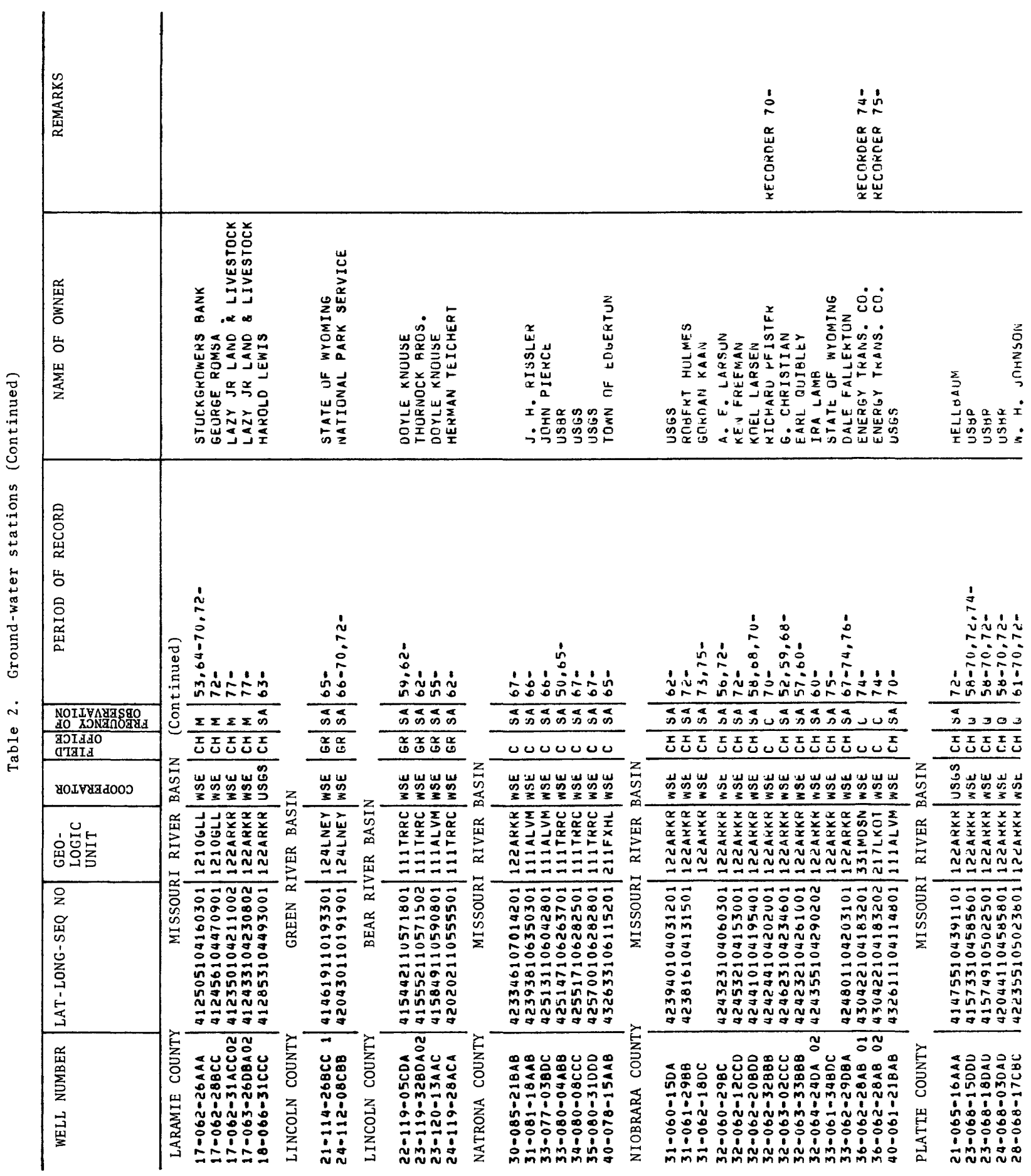




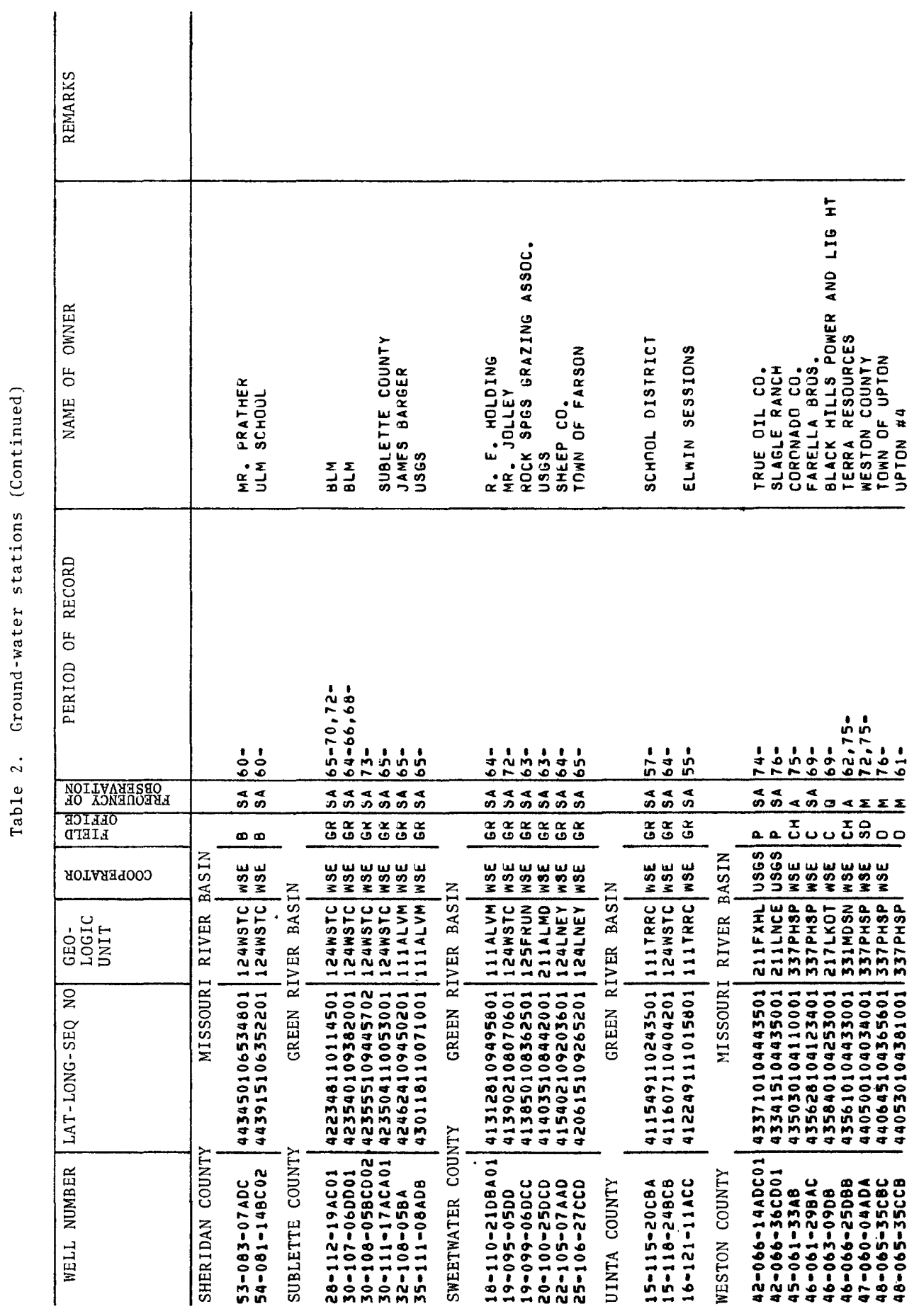


Water-quality stations 
Period of Record: The dates given are the calendar years in which records began or ended. Breaks of less than a year are not shown.

Location: $\mathrm{SE}$, section

TSP, township

RNGE, range

Cooperator: BLM, Bureau of Land Management

BRUC, Bureau of Reclamation, Upper Colorado Region

BRUM, Bureau of Reclamation, Upper Missouri Region

EPA, Environmental Protection Agency, Region 8

MRB, Geological Survey, Missouri River Basin Program

USGS, Geological Survey, Federal Program

WDA, Wyoming Department of Agriculture

WDEQ, Wyoming Department of Environmental Quality

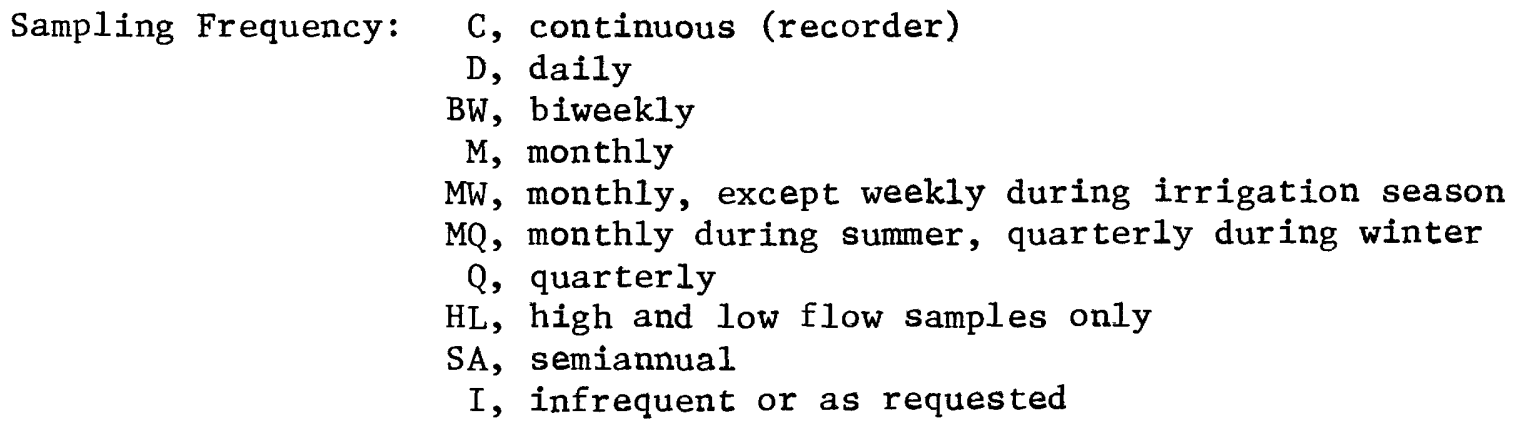

Analysis Schedule: 1, salinity (major constituents)

2 , specific conductance

3 , daily temperature (observed)

4 , bacteria or chemical oxygen demand

5, field determinations of: $\mathrm{pH}$, specific conductance, dissolved oxygen, temperature, and (or) turbidity

6, total coliform, fecal coliform, and (or) fecal streptococcus

7, nutrient

8 , trace metals

9 , pesticides

10, radiochemical

11 , biologica1

12, miscellaneous

Field Office: C, Casper

CF, Cheyenne Field Unit

$\mathrm{CH}$, Cheyenne Hydrologic

Surveillance Section

$\mathrm{CP}$, Cheyenne project personnel
CT, Contractor

GR, Green River

$\mathrm{R}$, Riverton

$W$, Worland 


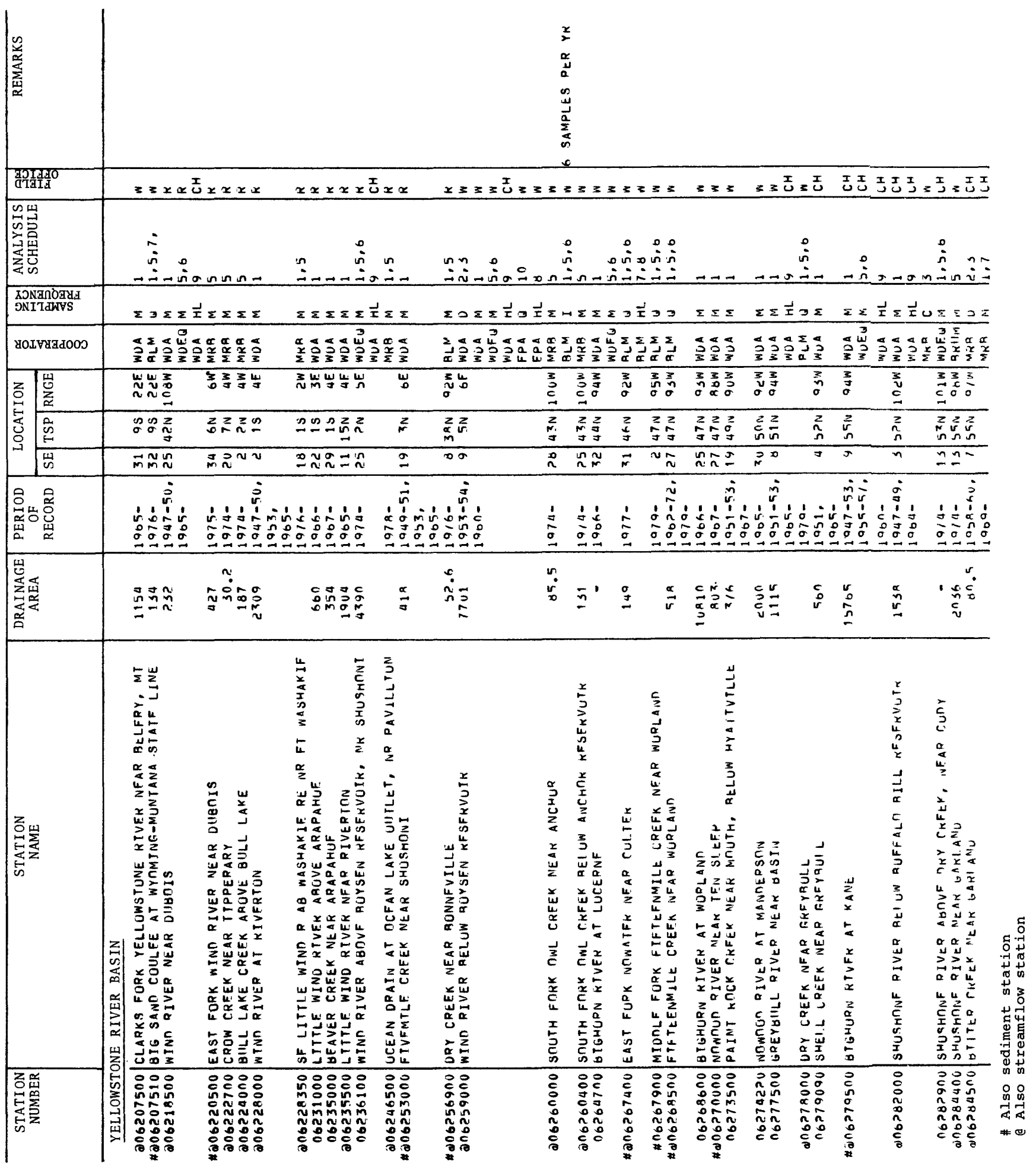




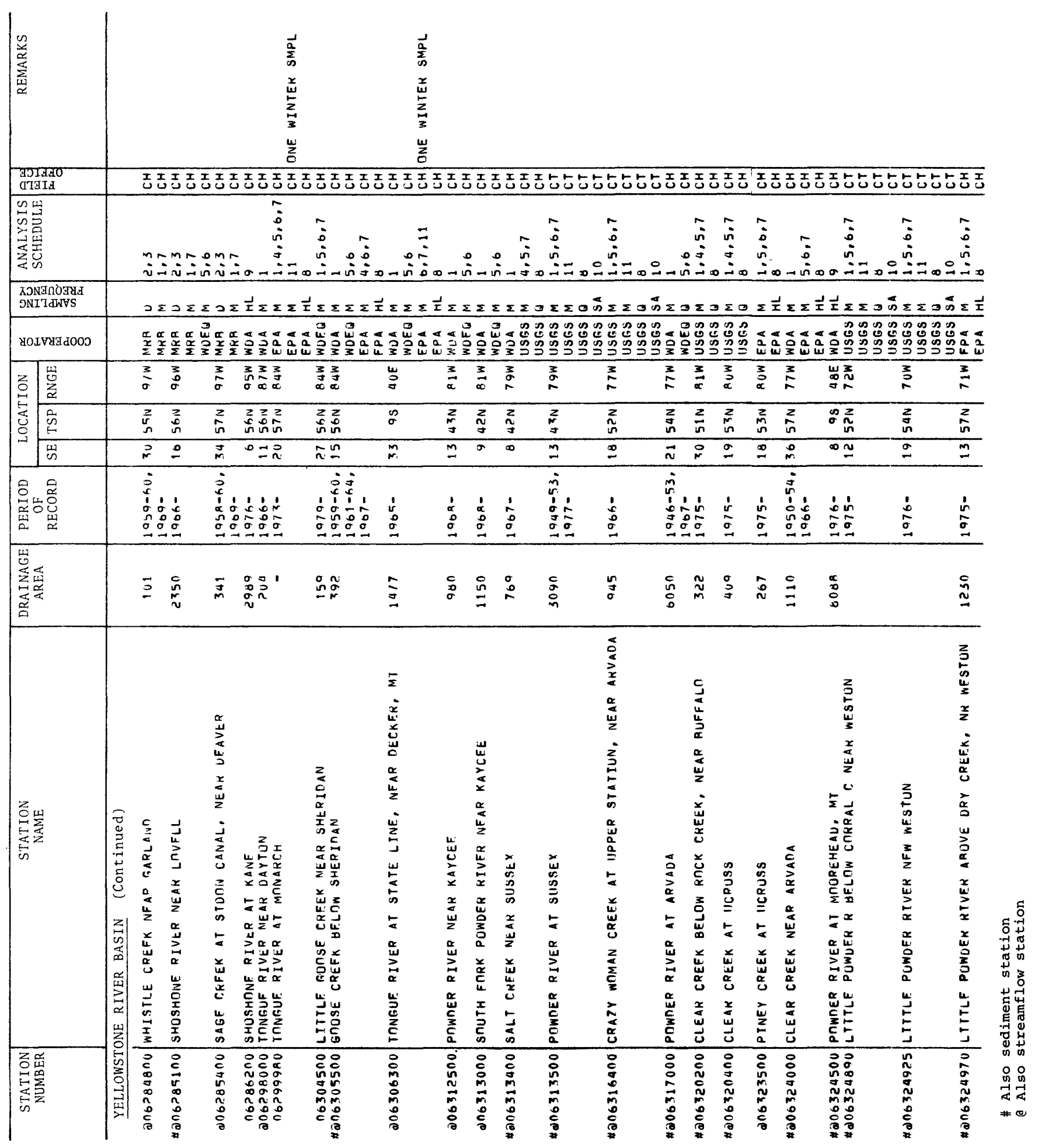




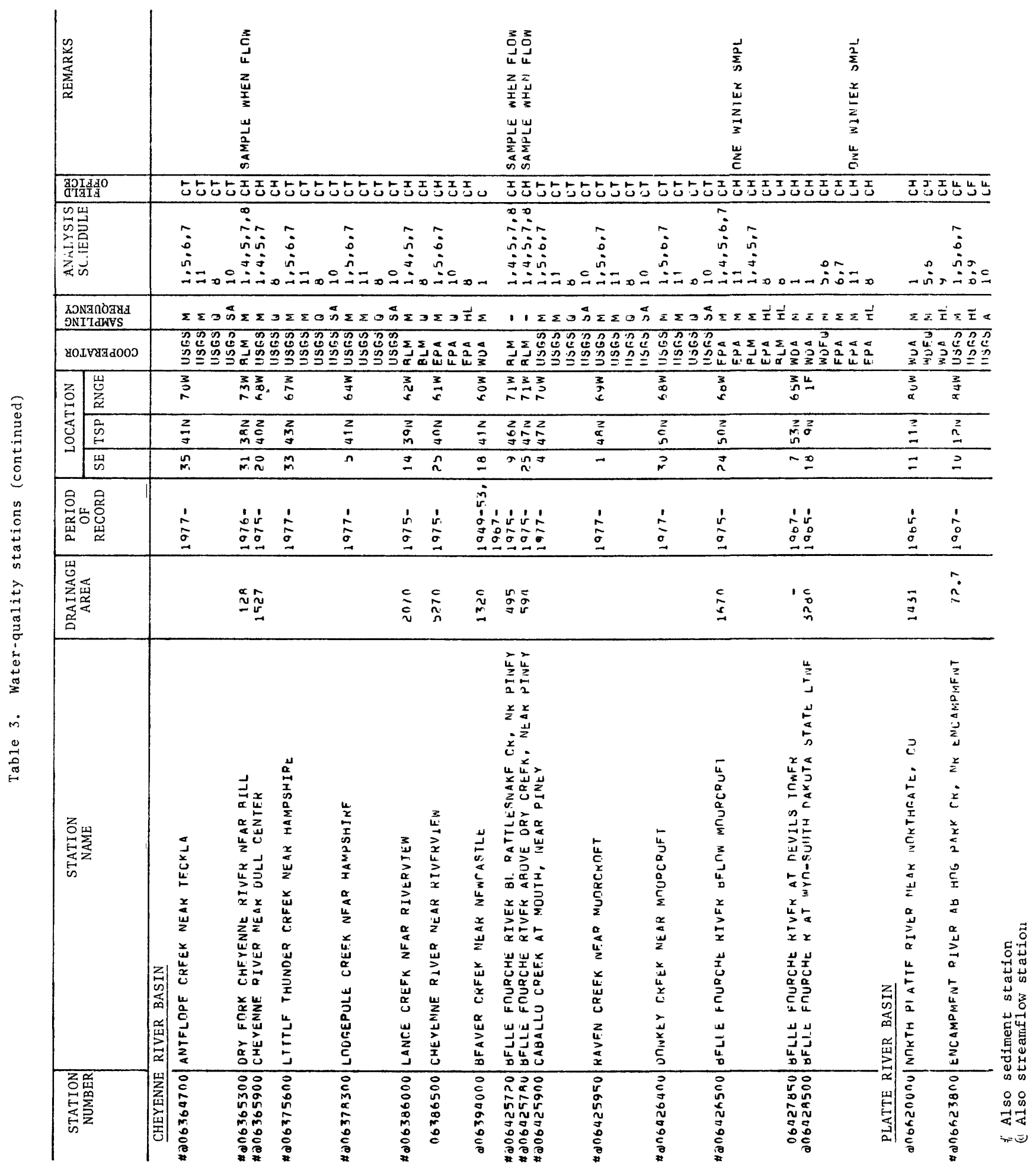




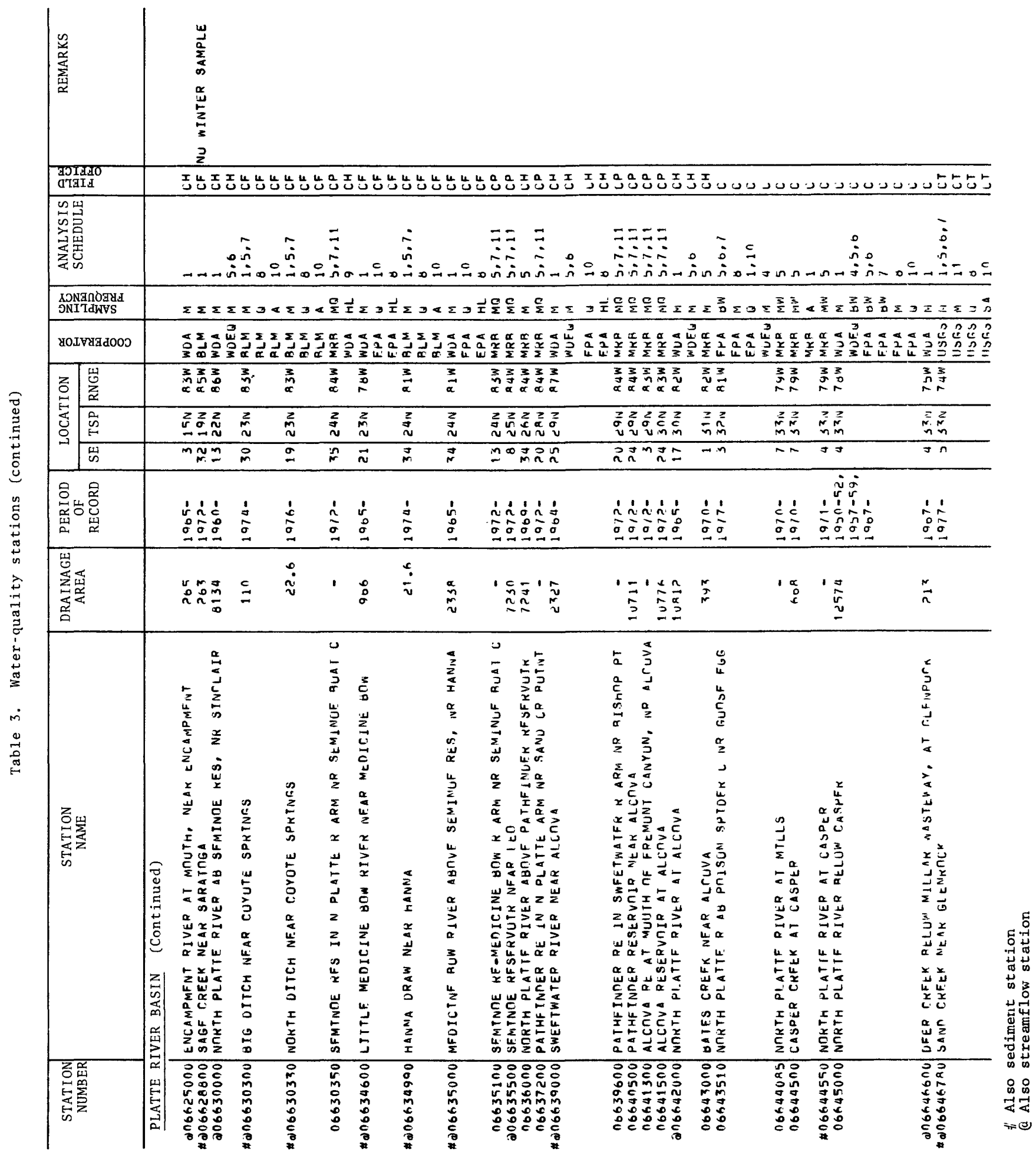




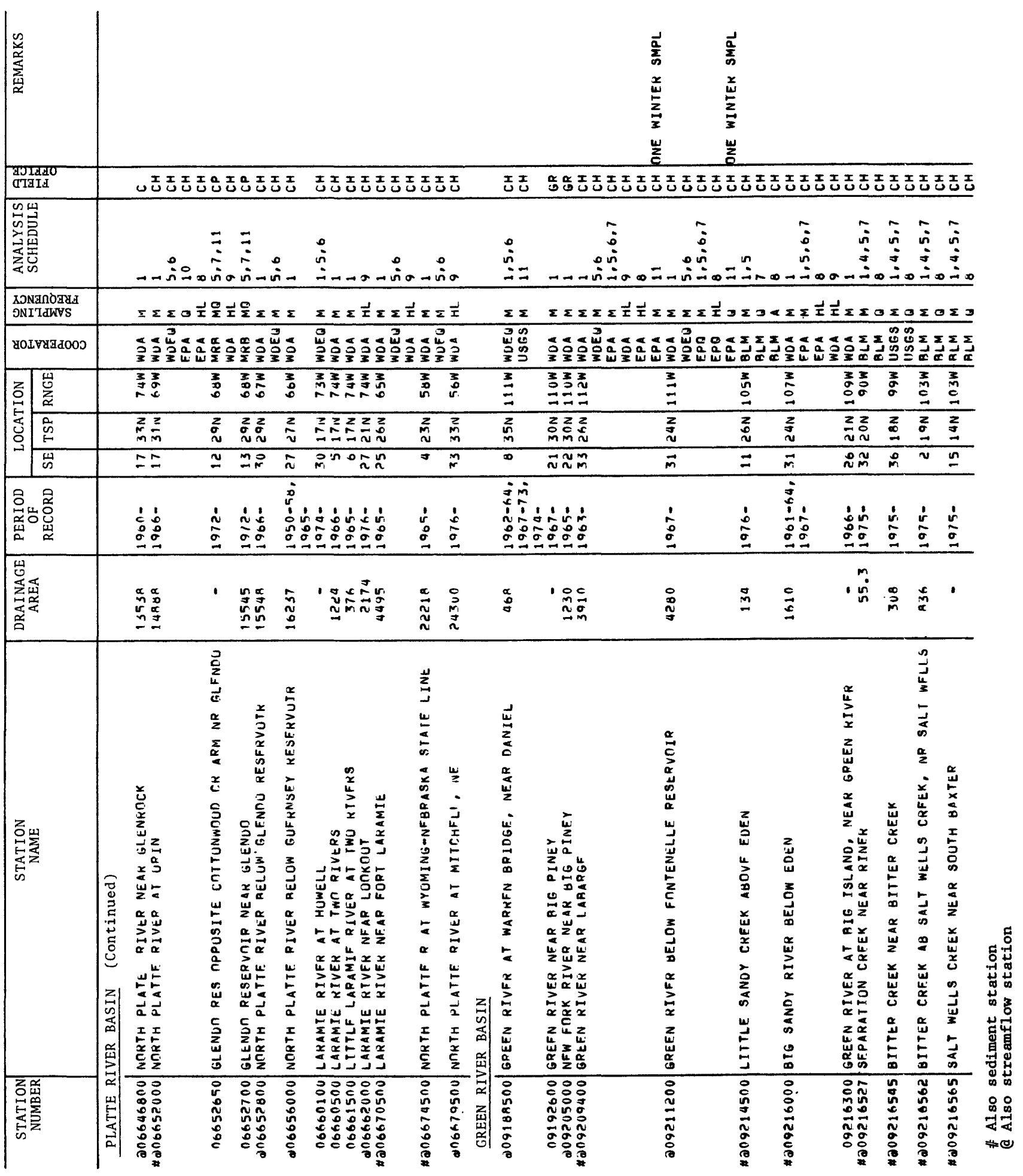




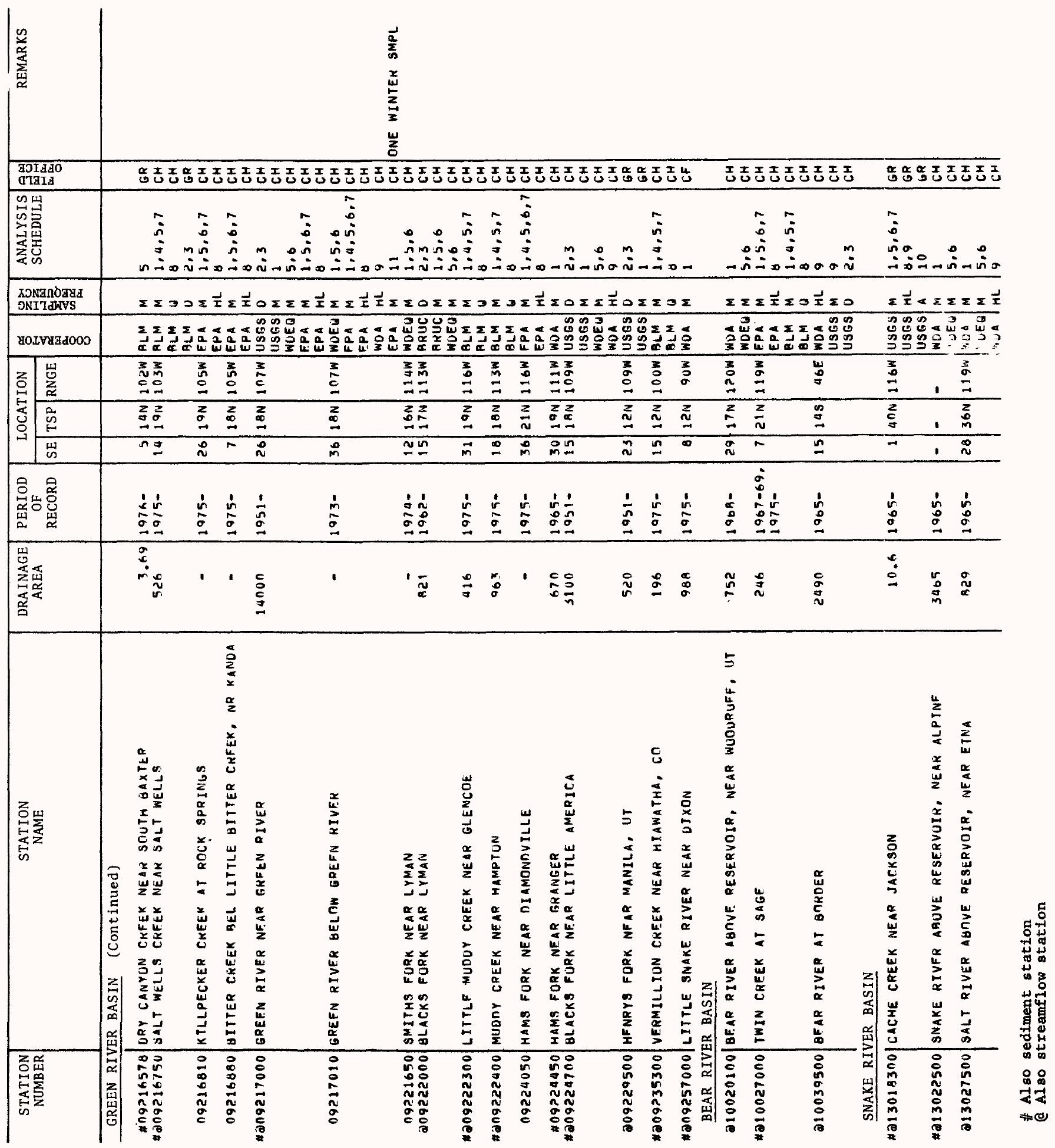


Sediment stations 
Explanation of abbreviations and codes used in table 4 .

Period of Record: The dates given are the calendar years in which records began or ended. Breaks of less than a year are not shown.

Location: $\mathrm{SE}$, section

TSP, township

RNGE, range

Sampling Equipment: $H$, hydrographer sample

0 , observer sample

$P$, pumping sampler

$\mathrm{S}$, single-stage samplers

Suspended Sediment Sampling Frequency:

1 , samples collected by observer once daily during operation except during perfods of rapidly changing flow when additional samples are collected.

2 , sampled by hydrographer at least once a month all year, with additional samples collected during periods of rapidly changing flow.

3 , sampled by hydrographer at least once a month during open-water perlod and at least twice during extended periods of ice cover.

4, sampled by hydrographer at least once a month Apr.-Sept.

5 , samples collected by Bureau of Reclamation weekly during irrigation season.

6, pumping sampler serviced monthly or more often during periods of high runoff.

7, single-stage sampler serviced at least monthly. Samples collected by hydrographer if there is flow at time of visit.

8 , infrequent sampling, sample when visiting station operated by WSE personnel.

9, sampled quarterly.

Bed Material Sampling Frequency:

3 , sample the surficial bed material in the cross section at least three times per year (high, medium, and low flow).

4, manual in-situ measurement and analysis of streambed material (pebble count), at a frequency of once per year (or longer), at the discretion of the District sediment specialist.

Suspended Sediment Analysis:

1 , suspended-sediment concentration.

$2,0.062 \mathrm{~mm}$ sieve analysis.

3, particle-size distribution.

4 , all of the above. 
Explanation of abbreviations and codes used in table 4.--Continued

Laboratory: W, Worland

Cooperator: BLM, Bureau of Land Management

BRUM, Bureau of Reclamation, Upper Missouri Region

MRB, Geological Survey, Missouri River Basin Program

USGS, Geological Survey, Federa1 Program

WSE, Wyoming State Engineer

Field office: B, Buffalo

CT, Contractor

C, Casper

GR, Green River

$\mathrm{CF}$, Cheyenne Field Unit

$R$, Riverton

$\mathrm{CH}$, Cheyenne Hydrologic

$W$, Worland

Surveillance Section 


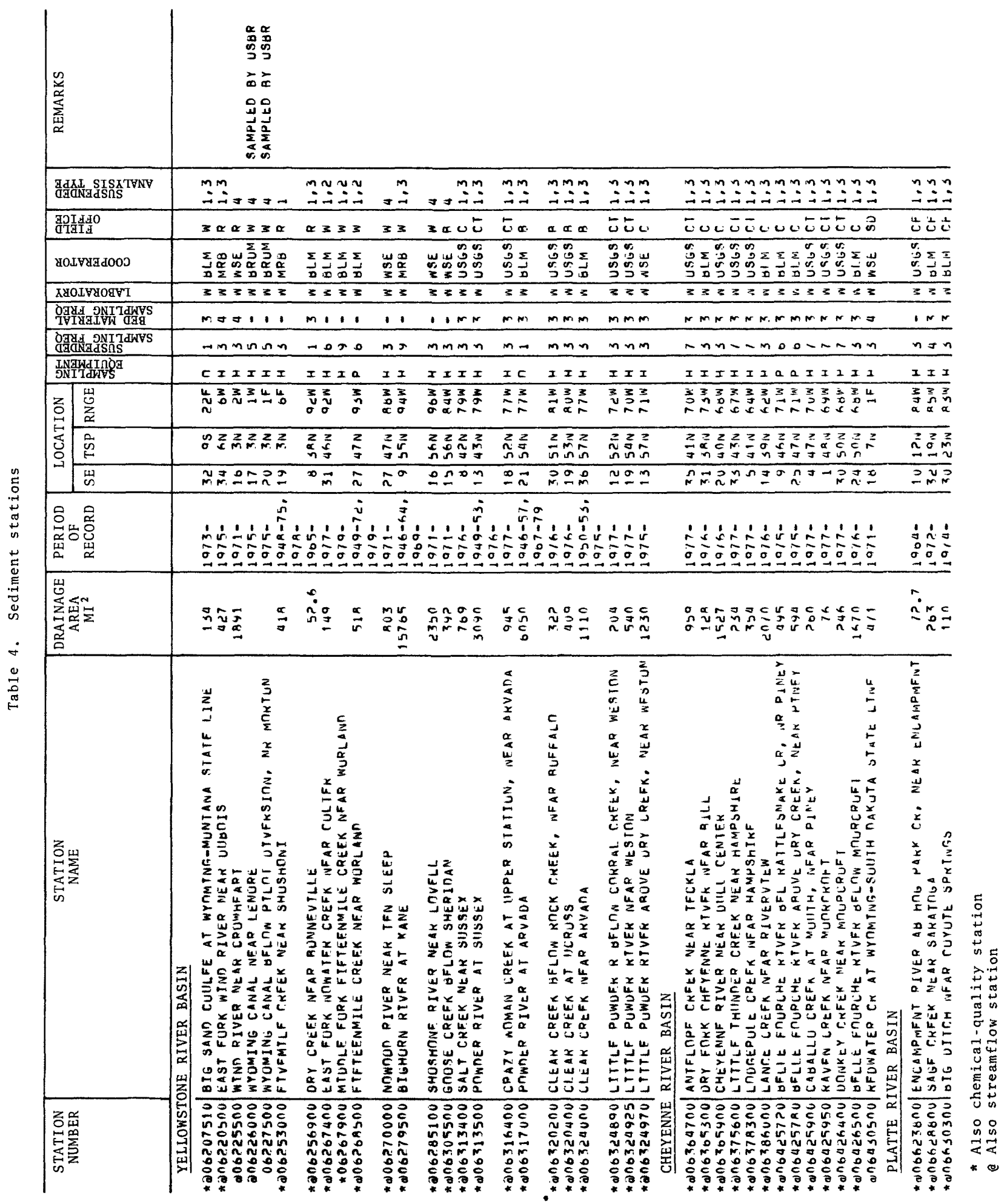




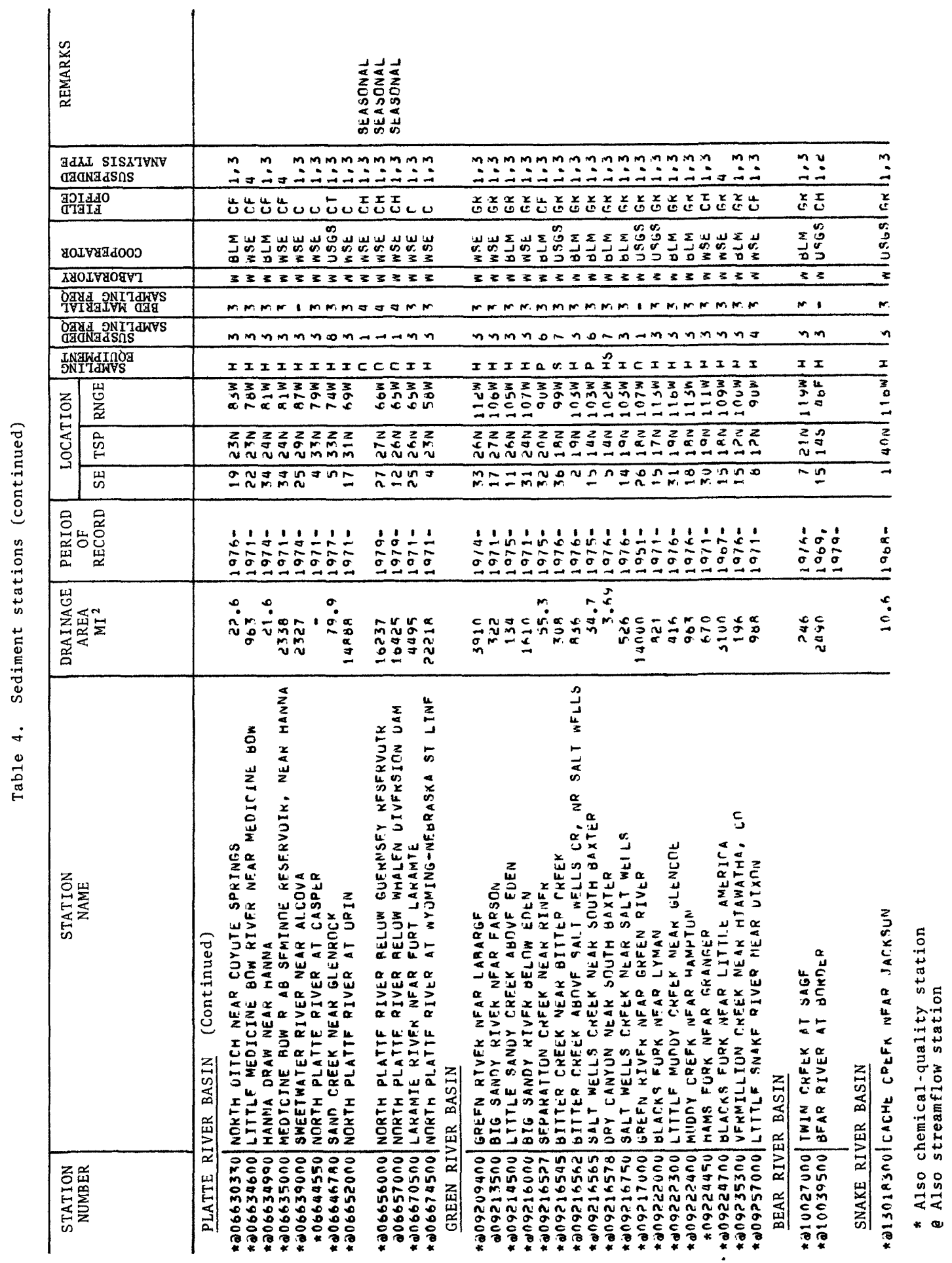


Peak-flow partial-record stations 
Explanation of abbreviations and codes used in table 5.

Location: SE, section

TSP, township

RNGE, range

Period of Record: The dates given are the calendar years in which records began or ended. Breaks of less than a year are not shown.

Gage Equipment: CSI, crest-stage indicator $S-R$, stage-rainfall recorder

Field Office: B, Buffalo

C, Casper

$C F$, Cheyenne Field Unit

GR, Green River

$\mathrm{R}$, Riverton

$\mathrm{W}$, Worland

Cooperator: BLM, Bureau of Land Management

WHD, Wyoming Highway Department 


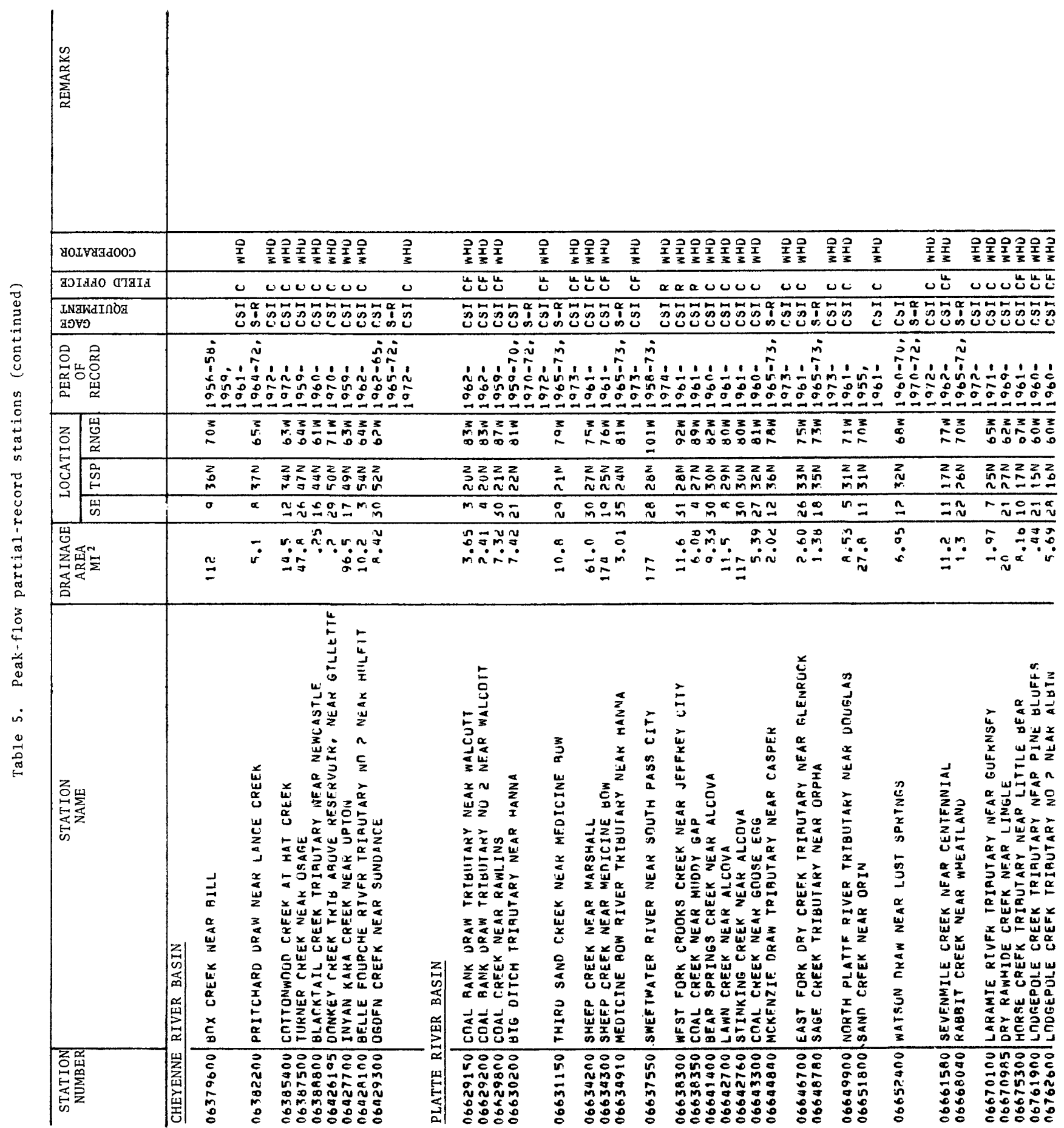




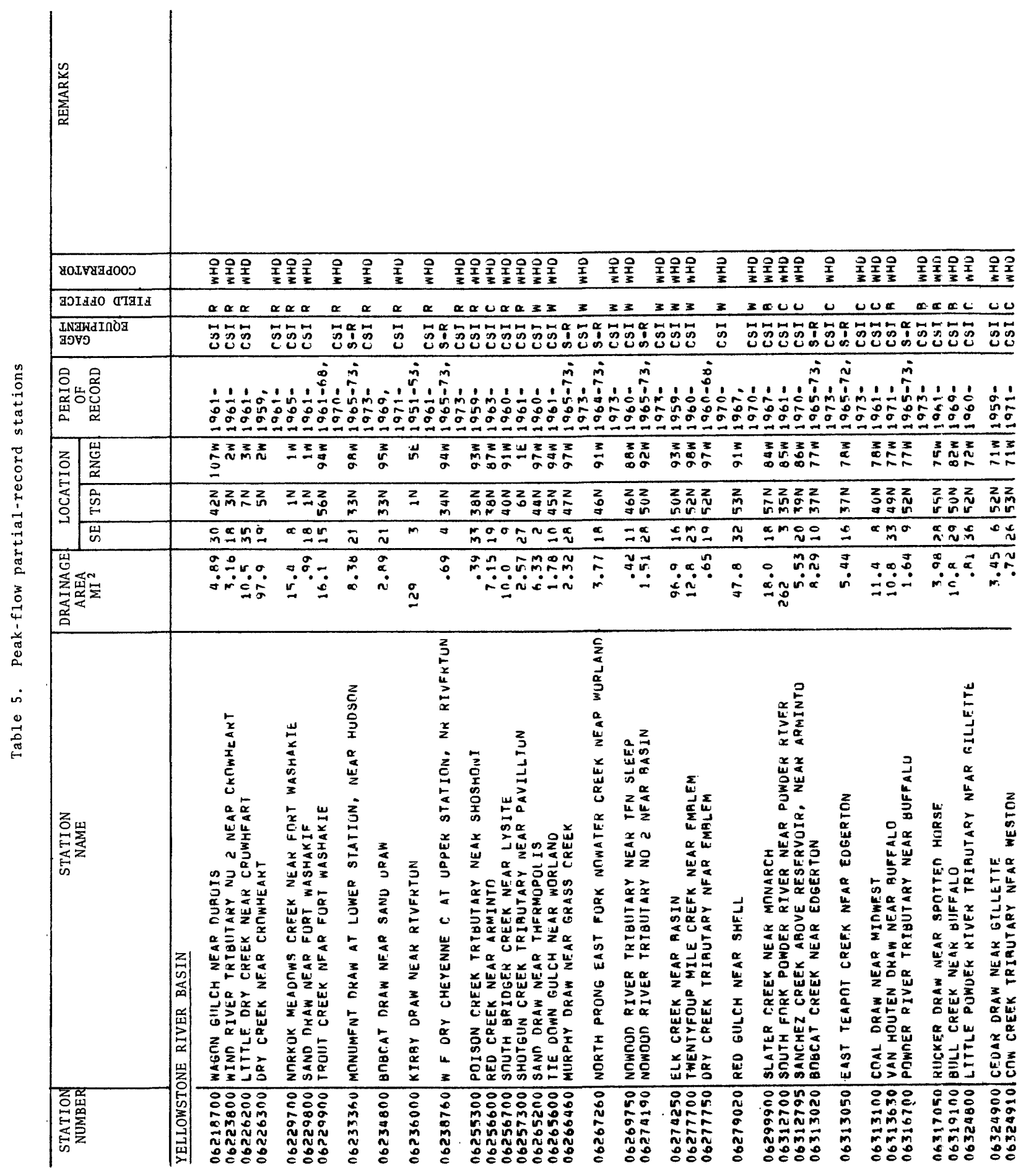




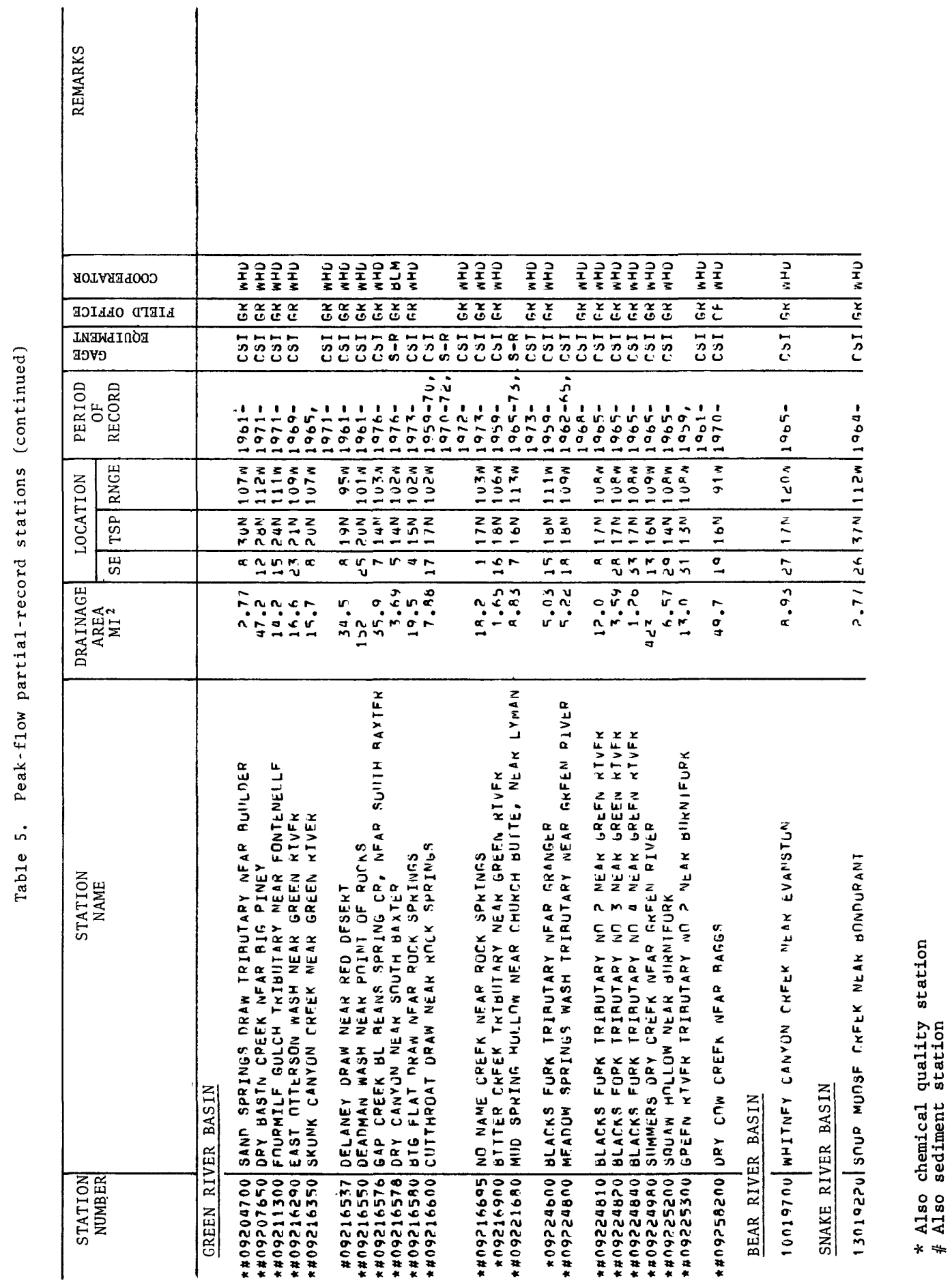




\section{WATER-RESOURCES PROJECTS}

The numerous water-resources projects being conducted in Wyoming are described in the following pages. The descriptions reflect project status as of October 1978. The project number is given following each title. All project leaders in the Wyoming district are located in the Cheyenne office.

The cooperating agencies during the fiscal year 1979 are shown for each project. The section "Progress and Significant Results" covers the period for fiscal year 1978. The area of each study is shown as either a shaded area or a large black dot on the index map near the title of each project. 
Water-Resources Projects Conducted by the Wyoming District 


\section{PROJECT TITLE: Surface-Water Stations (WY 00-001)}

COOPERATING AGENCY: Bureau of Land Management, Bureau of Reclamation, City of Cheyenne, Corps of Engineer, Utah State Engineer, Wyoming Department of Economic Planning and Development, Wyoming Department of Environmental Quality, Wyoming Game and Fish, and Wyoming State Engineer.

PROJECT LEADER: Ernest S. Denison.

FIELD LOCATION: Statewide.

PROBLEM: Surface-water information is needed for purposes of surveillance, planning, design, hazard warning, operation, and management in related fields such as water supply, hydroelectric power, flood control, irrigation, bridge and culvert design, wildlife management, pollution abatement, flood-plain management, and water resources development. To provide this information, an appropriate data base is necessary.

OBJECTIVE: (1) To collect surface-water data sufficient to satisfy needs for current-purpose uses such as (a) assessment of water resources, (b) operation of reservoirs or industries, (c) forecasting of stage or discharge, (d) pollution controls and disposal of wastes, (e) discharge data to accompany water-quality measurements, (f) compact and legal requirements, and $(\mathrm{g})$ research or special studies. (2) To collect data necessary for analytical studies to define for any location the statistical properties of, and trends in, the occurrence of water in streams, lakes, and estuaries for use in planning and design.

APPROACH: Standard methods of data collection will be used as descrited in the series, "Techniques of Water Resource Investigations of the United States Geological Survey," and partial-record gaging will be used where it serves the required purpose instead of complete-record gaging.

PROGRESS AND SIGNIFICANT RESULTS: Data collection was done on schedule and computation of the 1978 water year records was started. During the 1978 water year, six gaging stations were established and four rere discontinued. Several indirect measurements of flow were made to define rating curves. In addition, fifteen indirect determinations of peak flow were made for the May 1978 flood. A number of gaging stations were damaged by the high flow in May. The coal-lease monitoring project, WY-039, operated eleven additional streamflow stations in northeastern Wyoming. 
PLANS FOR FISCAL YEAR 1979: Operation of the present stream-gaging network will continue. Two new continuous-record stations will be established; Dry Creek near Greybull, and North Fork Shoshone River near Wapiti. A report on the floods of May 1978 in Wyoming and Montana will be published with the Montana District and the National Weather Service. Work on the annual data report for publication will continue.

REPORTS PUBLISHED DURING FISCAL YEAR 1978:

Boner, F.C., 1978, Water-resources investigations of the U.S. Geological Survey in Wyoming, Fiscal Year 1978: U.S. Geological Survey Open-File Report 78-239, 106 p.

Muench, R.L., 1977, Footbridge for measuring streamflow: U.S. Geological Survey WRD Bulletin, Apr.-Sept. 1977, p. 94-96.

Parrett, Charles, Carlson, D.D., Craig, Gordon S. Jr., Hull, J.A., 1978, Data for Floods of May 1978 in Northeastern Wyoming and Southeastern Montana: U.S. Geological Survey Open-File Report 78-985, $16 \mathrm{p}$.

U.S. Geological Survey, 1977, Water-resources data for Wyoming, Water Year 1976, Vo1. 1. Missouri River Basin: U.S. Geological Survey Water-Data Report WY-76-1, 631 p.

U.S. Geological Survey, 1978, Water-resources data for Wyoming, Water Year 1976, Vo1. 2. Green River, Bear River, and Snake River Basins: U.S. Geological Survey Water-Data Report WY-76-2, $436 \mathrm{p}$.

PROJECT TITLE: Ground-Water Stations (WY 00-002)

COOPERATING AGENCY: Wyoming State Engineer and City of Cheyenne.

PROJECT LEADER: Jess 0. Ragsdale.

FIELD LOCATION: Statewide.

PROBLEM: (1) Long-term water-level records are needed to evaluate the effects of climatic variations on the recharge to and discharge from the ground-water systems to provide a data base from which to (a) measure the effects of development, (b) to assist in the prediction of future supplies, and (c) to provide data for management of the resource. (2) Short-term water-level records are also needed for (a) assessment of ground-water resources, (b) areal investigations, and (c) water-use investigations. 
OBJECTIVE: (1) To collect water-level data sufficient to provide a minimum long-term data base so that the general response of the hydrologic system to climatic variations and induced stresses is known, and, so that potential problems can be defined early enough to allow planning and management. (2) To provide a data base against which short-term records acquired in areal studies can be analyzed. This analysis must provide (a) an assessment of the ground-water resource, (b) allow prediction of future conditions, (c) detect and define pollution and supply problems, and (d) provide the data base necessary for ground-water management.

APPROACH: The most advantageous locations for long-term observations will be determined and this network will be refined as records becone available and detailed areal studies of the ground-water system more closely define the aquifers, their properties, and the stresses to which they are subjected.

PROGRESS AND SIGNIFICANT RESULTS: During the 1978 water year, a total of about 1,200 water-level measurements were made in about 290 wells. Early in 1978, mass water-level measurements were made in areas of heavy pumpage in southeastern Wyoming. The compilation of water levels measured in calendar year 1977 was completed and net changes between 1976 and 1977 were computed. The 1977 data, together with water-level hydrographs for the period 1968-77, were published in the U.S. Geological Survey Open-File Report 78-605.

PLANS FOR FISCAL YEAR 1979: The observation-well network will be evaluated for geographic and hydrologic coverage. Changes in the network will be made as opportunities occur. As interpretive grounwater projects are completed, project wells will be selected for addition to the network, particularly in southeastern Wyoming. Water levels will be measured at all wells at frequencies similar to those of 1978. Where a need is indicated, some wells will be tested to check that they are open to the aquifer. An open-file report containing the 1978 data and hydrographs for 1969-78 will be prepared. 
REPORTS PUBLISHED DURING FISCAL YEAR 1978:

Boner, F.C., 1978, Water-resources investigations of the U.S. Geological Survey in Wyoming, Fiscal Year 1978: U.S. Geological Survey Open-File Report 78-239, 106 p.

Stevens, M.D., 1978, Ground-water leve1s in Wyoming, 1977: U.S. Geological Survey Open-File Report 78-605, 203 p.

U.S. Geological Survey, 1977, Water levels in the United States, 1971-74, northwestern states: U.S. Geological Survey Water-Supply Paper 2161, p. 141-153.

U.S. Geological Survey, 1977, Water-resources data for Wyoming, Water Year 1976, Vo1. 1. Missouri River Basin: U.S. Geologica1 Survey Water-Data Report WY-76-1, $631 \mathrm{p}$.

U.S. Geological Survey, 1978, Water-resources data for Wyoming, Water Year 1976, Vo1. 2. Green River, Bear River, and Snake River Basins: U.S. Geological Survey Water-Data Report WY-76-2, 436 p.

PROJECT TITLE: Water-Quality Stations (WY 00-003)

COOPERATING AGENCY: Bureau of Land Management, Bureau of Reclamation, Environmental Protection Agency, Wyoming Department of Agriculture, and Wyoming Department of Environmental Quality.

PROJECT LEADER: Joel R. Schuetz.

FIELD LOCATION: Statewide.

PROBLEM: Water resource planning and water-quality assessment require a nationwide base level of relatively standardized information. For intelligent planning and realistic assessment of the water resource, the chemical and physical quality of the rivers and streams must be defined and monitored.

OBJECTIVE: To provide a national bank of water-quality data for broad federal planning and action programs and to provide data for State and Federal management of interstate waters.

APPROACH: Operate a network of water-quality stations to provide data on average chemical concentrations, loads, and trends as required by planning and management agencies. 
PROGRESS AND SIGNIFICANT RESULTS: During the year, data collection was continued on schedule. Work continued throughout the year on preparation of the annual data reports. Salinity sampling on eight stations operated in the Bighorn Basin was discontinued at the end of the water year. The NASQAN (National Stream-Quality Accounting Network) station on the Snake River near Alpine was discontinued and a NASQAN sampling station was started on Bear River near Border. Analysis for dicambra and picloram was added at twenty stations to supplement the herbicide study (Project 77-043).

PLANS FOR FISCAL YEAR 1979: Most data-collection activities will continue with only minor changes during the year. An evaluation of all programs will continue and it is hoped that the data from some of the long-term trend stations can be statistically analyzed during the year. This analysis would be used in planning and re-evaluating changes in the water-quality program.

REPORTS PUBLISHED DURING FISCAL YEAR 1978:

Boner, F.C., 1978, Water-resources investigations of the U.S. Geological Survey in Wyoming, Fiscal Year 1978: U.S. Geologica:Survey Open-File Report 78-239, 106 p.

U.S. Geological Survey, 1977, Water-resources data for Wyoming, Water Year 1976, Vo1. 1. Missouri River Basin: U.S. Geological Survey Water-Data Report WY-76-1, 631 p.

U.S. Geological Survey, 1978, Water-resources data for Wyoming, Water: Year 1976, Vo1. 2. Green River, Bear River, and Snake River Basins: U.S. Geological Survey Water-Data Report WY-76-2, 436 p.

PROJECT TITLE: Sediment Stations (WY 00-004).

COOPERATING AGENCY: Bureau of Land Management, Bureau of Reclamation, and Wyoming State Engineer.

PROJECT LEADER: Harold B. Fabricius.

LOCATION: Statewide.

PROBLEM: Water resource planning and water-quality assessment require a nationwide base level of relatively standardized information.

Sediment concentrations and discharges in rivers and streams must be defined and monitored. 
OBJECTIVE: The major objectives are (1) to provide a national bank of sediment data for use in broad Federal and State planning and actjon programs, (2) to provide data for Federal and State management of interstate waters, and (3) to provide data for interpretation in areal studies.

APPROACH: A network of sediment stations will be established and of erated to provide data on areal and temporal averages and trends of sedimont concentration, sediment discharges, and particle size distributior of sediment being transported by rivers and streams.

PROGRESS AND SIGNIFICANT RESULTS: The collection and processing for publication of sediment data continued on schedule for 119 statiors, 5 of which were sampled daily by local observers. Concentration data were collected at al1 stations and bed material at 109 stations. Three sites had pumping samplers and 26 sites had single-stage sanolers. One daily station was discontinued. Miscellaneous sampling prograns for BLM in the Bighorn Basin and a USGS oil shale project in the Green River Basin were completed. The Worland laboratory processef 28,766 bottles of samples while performing 17,743 concentration analyses, 891 sieve analyses $(-.062 \mathrm{~mm}), 343$ suspended-size analyses, and 278 other size analyses. About half of this laboratory work was for the Montana and North Dakota Districts. Analysis of data for 20 sites was started; preliminary results indicate fairly good correlation between sediment discharge and water discharge at a11 20 sites.

PLANS FOR FISCAL YEAR 1979: Field and laboratory workloads will be smaller in fiscal year 1979. The Wyoming network will consist of about 62 stations, including 5 sampled daily by observers and 3-5 with automatic samplers. The station, Powder River at Arvada, may be changed from daily to monthly. A total of 43 stations will be operated under contract for coal-lease monitoring in Wyoming, Montana, and North Dakota. Lab work for Wyoming and Montana will decrease because of discontinued stations. The Wyoming District will assirt QW Branch by collecting special sediment material to be used in preparation of standard samples for a nationwide quality-control check of sediment laboratories.

REPORTS PUBLISHED DURING FISCAL YEAR 1978:

Boner, F.C., 1978, Water-resources investigations of the U.S. Geological Survey in Wyoming, Fiscal Year 1978: U.S. Geological Survey Open-File Report 78-239, 106 p.

U.S. Geological Survey, 1977, Water-resources data for Wyoming, Water Year 1976, Vol. 1. Missouri River Basin: U.S. Geological Survey Water-Data Report WY-76-1, 631 p.

U.S. Geological Survey, 1978, Water-resources data for Wyoming, Water Year 1976, Vol. 2. Green River, Bear River, and Snake River Basins: U.S. Geological Survey Water-Data Report. WY-76-2, 436 p. 
PROJECT TITLE: Flood investigations in Wyoming (WY 59-010).

COOPERATING AGENCY: Wyoming Highway Department.

PROJECT LEADER: Gordon S. Craig, Jr.

FIELD LOCATION: Statewide.

PERIOD OF PROJECT: July 1958 to June 1983.

PROBLEM: The optimal design of highway drainage structures requires a knowledge of the magnitude and frequency of peak discharges expectef at a given site. This knowledge may be derived either from data collected at the desired location or from regional analysis of peakflow characteristics. The paucity of peak-flow data for small drainage basins in Wyoming, particularly for ephemeral streams, restricts the use of the regionalization techniques presently available. A network of peak-flow partial-record sites is needed to supplement the existing network of continuous-record streamflow stations.

OBJECTIVE: The main objective is to obtain sufficient basic hydrologic data to define the magnitude and frequency of floods on a regional basis for the entire state and to publish the interpretative analyses in easily usable form. On request from the cooperator, flood-flow characteristics of streams at specific sites will be determined by studying such factors as: History of past floods; distribution of flow across the flood-plain and main channel; and mean velocities in the main channel and overflow areas.

APPROACH: Available flood data will be analyzed, and sites for crest stage gages will be selected where they will best supplement the existing network of continuous-record stream-gaging stations. Stagedischarge relations will be defined for each crest-stage site by recording water stage and by making current-meter measurements, indirect measurements of peak flow, or by using the "step-backwater method." Basin characteristics that are pertinent in flood-frequency analysis will be determined. Frequency characteristics will be related to basin characteristics by regression analysis. Peak-flow measurements will be made at miscellaneous sites where unusual floods occur.

PROGRESS AND SIGNIFICANT RESULTS: The crest-stage gage network continued in operation without major change. The annual peak data files were updated to include a11 1977 water-year data and some 1978 peak flows resulting from the floods of May 1978. Indirect discharge measurements were made on flood peaks at four crest-stage sites and two miscellaneous sites. A method was developed for estimating inflow peaks at culverts where highway embankments create extensive storage ponding. A description of the method was published in the Water Resources Division Bulletin January-June, 1978. 
PLANS FOR FISCAL YEAR 1979: Efforts to relocate the crest-stage gages on ephemeral streams, especially in northeaster Wyoming, will continue. Special hydraulic and hydrologic studies at bridges and culverts will be made when requested by the Wyoming Highway Department. Miscellaneous measurements will be made where outstanding floods occur.

REPORTS PUBLISHED DURING FISCAL YEAR 1978:

Craig, G.S., Jr., 1978, Estimating inflow peaks at culverts where ponding has occurred: U.S. Geological Survey WRD Bulletin, Jan.-June, 1978, p. 60-64.

Parrett, Charles, Carlson, D.D., Crałg, Gordon S. Jr., Hull, J.A., 1978, Data for Floods of May 1978 in Northeastern Wyoming and Southeastern Montana: U.S. Geological Survey Open-File Report 78-985, $16 \mathrm{p}$.

PROJECT TITLE: Hydrologic evaluation of the Arikaree Formation near Lusk, Wyoming (WY 74-024).

COOPERATING AGENCY: Wyoming Department of Planning and Development.

PROJECT LEADER: Marvin A. Crist.

FIELD LOCATION: East-central Wyoming.

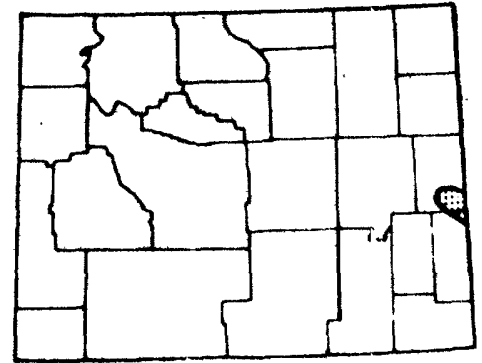

PERIOD OF PROJECT: July 1973 to September 1979.

PROBLEM: The Arikaree Formation contains a large amount of water suitable in quality for domestic, industrial, and agricultural uses. Many irrigation wells have been developed near Lusk, Wyoming; yields greater than $500 \mathrm{gal} / \mathrm{min}$ are not uncommon. The number of irrigation wells in the Arikaree increases each year. Development of nearby energy resources will increase the need to use ground water for industrial purposes. State water planners have no guidelines for regulation of ground-water development in the area. A study is needed that will describe the ground-water system in detail and provide. information on the cause-and-effect of ground-water development.

OBJECTIVE: The objectives are (1) to define the ground-water system in more detall than was done in previous studies; (2) to determine the cause-and-effect relationship of current ground-water development; and (3) to provide a means of predicting cause-and-effect relationship of future ground-water development. 
APPROACH: Inflow and outflow of all water will be inventoried and a water budget prepared. This will require Inventories of all larg:capacity wells, records of stream diversions for irrigation, pumpage, and acreage irrigated. Hydraulic properties will be determined primarily from aquifer tests. Surface geology and the configuration of the base of the Arikaree will be shown on maps. The water-levsl surface will be contoured and a saturated thickness map prepared. A digital model will be prepared to simulate hydrologic condition in the Arikaree. The model will be used to determine the cause-andeffect relationship of ground-water development in the aquifer.

PROGRESS AND SIGNIFICANT RESULTS: Pumpage was updated through 1976. The digital model was revised with the new pumpage and proposed development in 1977 and 1978. The model was used to predict the effect of the new stress. Results calculated with the model are used by the Wyoming State Engineer as a guide to administer ground-water development in the area.

PLANS FOR FISCAL YEAR 1979: The relatively small amount of annual activity will consist of updating well inventory and pumpage information, and incorporating the new data into the digital model af the ground-water system.

REPORTS PUBLISHED DURING FISCAL YEAR 1978:

Crist, M.A., 1977, Hydrologic evaluation of the Arikaree Formation near Lusk, Nlobrara and Goshen Counties, Wyoming: U.S. Geological Survey Water-Resources Investigations 77-111, 23 p., 3 p1.

PROJECT TITLE: Water resources of Weston County, Wyoming (WY 74-026).

COOPERATING AGENCY: Wyoming State Engineer.

PROJECT LEADER: Marlin E. Lowry.

FIELD LOCATION: Northeastern Wyoming.

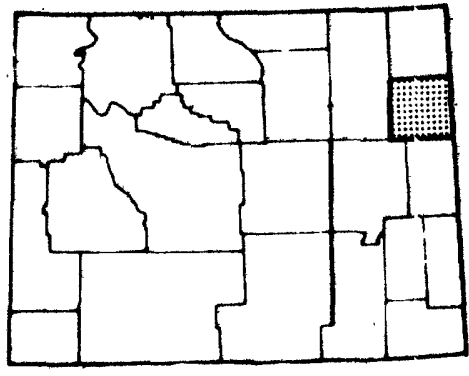

PERIOD OF PROJECT: March 1974 to June 1976 (incomplete). 
PROBLEM: The demand for ground water will probably increase rapidly in Weston County because of its proximity to the coal deposits in the. Powder River Basin and the fact that potential aquifers are at relatively shallow depths, compared to depths in the areas where coal will be mined. Industrial, municipal, and much of the agricultural supplies in the county are obtained from ground water. There are no major perennial streams in the area. The ground-water resources of the county have not been adequately evaluated for orderly developmont of these resources.

OBJECTIVE: The objectives are to determine (1) the distribution (areally and vertically) and thickness of each of the principal aquifers or aquifer systems; (2) the movement of water in each of the principal aquifers or aquifer systems; (3) the hydraulic characteristics for each principal aquifer or aquifer system; (4) the waterbearing properties of subordinate aquifers; (5) the volume of ground water in storage; (6) the quality of water in each aquifer; (7) tro quantity of runoff from small watersheds; (8) the quality of runoff at gaged sites; (9) the effect of ground-water withdrawal on water levels; and (10) to evaluate the potential for artificial recharge.

APPROACH: A well inventory will be made and periodic water-level measurements taken. Water samples will be collected and analyzed. Pumping tests will be made to determine aquifer characteristics. Rock samples will be collected and analyzed for water-bearing characteristics. Cross sections of major drainages will be augered. Ground water use will be inventoried. Existing data will be tabulated, and a geolcgic map and cross sections will be compiled. Structure-contour and is opach maps of the principal aquifers will be prepared. The volume of ground water in storage (by aquifer) will be calculated and shown on maps. Potentiometric and depth-to-water maps for principal aquifers will be constructed. Well-field histories will be analyzed. The potentie 1 for artifical recharge will be evaluated. Runoff characteristics for small basins will be described using channel geometry techniques.

PROGRESS AND SIGNIFICANT RESULTS: No work was done in fiscal year 1978. Final report is nearly completed.

PLANS FOR FISCAL YEAR 1979: Complete the final report and pub1ish it in the WRI series.

REPORTS PUBLISHED DURING FISCAL YEAR 1978: None. 
PROJECT TITLE: Monitoring wastewater effluent in Yellowstone and Grand Teton National Parks, Wyoming (WY 74-027).

COOPERATING AGENCY: National Park Service.

PROJECT LEADER: Edward R. Cox.

FIELD LOCATION: Northwestern

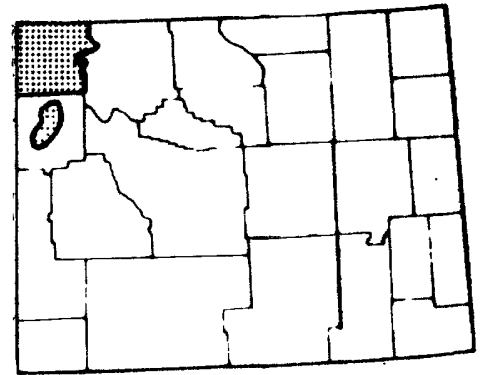
Wyoming.

PERIOD OF PROJECT: June 1974 to September 1981.

PROBLEM: The National Park Service is constructing new or rehabilitating existing evaporation-percolation ponds at several sewage wastewater treatment and disposal sites in Yellowstone and Grand Teton National Parks. The sites (four in Yellowstone and two in Grand Teton) are near streams or lakes. The National Park Service needs to determine the effects of the wastewater effluent on the ecosyster of the parks. In order to do this, they need to know the amount, direction, and velocity of movement of the effluent that percolates from the ponds. Additional sites may be added to the study.

OBJECTIVE: The objectives are to determine (1) the position of the water table and its relation to the ponds and nearby surface-water bodies; (2) the slope of the water table and thus the direction of movement of the effluent; (3) the ground-water velocities and thus the time-of-travel of effluent from pond to surface-water body; (4) the vertical zone of movement of the effluent; and (5) the baseline water quality in the shallow aquifers in the vicinity of the percolation ponds and in surface-water bodies.

APPROACH: Wells will be installed in unconsolidated material near tho sewage ponds. About 30 wells in Yellowstone and about 9 wells in Grand Teton will be needed for the project. Aquifer tests will be made by pumping from selected wells. Tracer tests will be made in a few selected wells. Water samples will be collected from the wells and analyzed for chemical and bacteriological quality of the water. Water levels in the wells will be measured periodically. A program of monitoring water quality will be established following preliminary sampling and calculations of ground-water velocity determined from the hydraulic and tracer tests. 
PROGRESS AND SIGNIFICANT RESULTS: Water levels were measured approx1mately monthly during autumn, spring, and summer in about 40 wells at the four study sites in Yellowstone. About 30 water samples were collected from wells, effluents, and nearby streams and analyzed for dissolved carbon, nitrogen, phosphorus, and other constituents. In addition, about 50 samples were collected from wells and effluents and analyzed for chloride and sulfate. A report containing data collected during the 15-month period ending September 1976 and describing wastewater movement near the sites was released to the open file and transmitted to the National Park Service. A similar report containing data collected and interpretations of wastewater movement for 'fiscal year 1977 was prepared and is in review.

PLANS FOR FISCAL YEAR 1979: Measuring of wells and sampling of wells, effluents, and streams at the four study sites in Yellowstone will continue. A report describing data collected and interpretations made for fiscal year 1978 will be prepared for open-file release.

REPORTS PUBLISHED DURING FISCAL YEAR 1978:

Cox, E. R., 1978, Preliminary study of wastewater movement in Yellowstone National Park, Wyoming, July 1975 through September 1976: U.S. Geological Survey Open-File Report 78-227, 54 p.

Cox, E.R., 1978, Iron in water near wastewater lagoons in Yellowstone National Park, Wyoming: in Journal of Research of the U.S. Geological Survey, v. 6, no. 3, May-June, 1978, p. 319-324.

PROJECT TITLE: Water and its relation to economic development in the Green River and Great Divide basins in Wyoming (WY 75-030).

COOPERATING AGENCY: Bureau of Land Management.

PROJECT LEADER: Hugh W. Lowham.

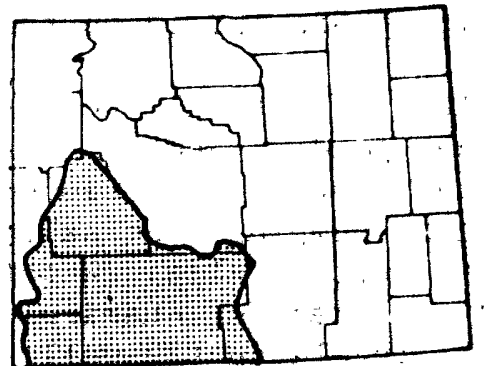

FIELD LOCATION: Southwestern Wyoming.

PERIOD OF PROJECT: November 1974 to September 1979. 
PROBLEM: Development of extensive coal, oil, gas, trona, and oil-splale resources in the project area will require a projected increase in water consumption of 480,000 acre-ft per year by 1990 . Development of energy resources in other parts of the State also will require large amounts of water; transbasin diversion of Green River water to other areas could total an additional 270,000 acre-ft per year. Water planners and managers need much more information about avai]able ground and surface water, present quality of the waters, and the impacts on water supply and quality caused by development of energy resources.

OBJECTIVE: The study will be designed to gather information, and tc make available to interested industrial, agricultural, and governmental people, interpretive reports that describe (1) the distribution and quality of surface water in space and time; (2) the relationships between surface water and ground water; (3) the distributior, quantity, and quality of ground water; and (4) the hydrology-relatied aspects of the environment. Efforts of the study will be directed. toward (1) describing the water resources and hydrologic relationships that presently exist; (2) developing predictive methods that. may be used to describe future conditions, including reactions to increased water development; and (3) establishing monitoring programs for detecting possible changes in water parameters.

APPROACH: Existing water data will be compiled and evaluated. A literature search for present hydrologic knowledge of the area will be conducted. A planning report will be prepared during the first. year of the project, outlining the specific techniques to be used in subsequent phases. Regarding water quality, particular attention will be given to trace metals, biological parameters, and trend analyses. Channel-geometry techniques, LANDSAT imagery, and detailed statistical analyses will be applied to surface-water studies. Aquifer tests and bore hole and surface geophysical surveys will be used in ground-water studies. Digital models will be developed for chemical-quality ard surface-water systems.

PROGRESS AND SIGNIFICANT RESULTS: An intensive sampling program was conducted during the fall and spring, using a helicopter and eight. hydrologists. Water-quality samples and field measurements were collected at several hundred surface- and ground-water sites. A preliminary analysis indicated abnormally high concentrations of lead, cadmium, and selenium in waters near Baggs, Wyoming. The computer is being used to analyze the water-quality data that have been collected during the past few years. Up-to-date data lists were retrieved. Computer-drawn maps, trilinear diagrams, and histograms are being made. Explanation of WRD activities in the study area and results to date were presented to State and Federal agencies at a special meeting in March 1978. A second meeting was held in July at Rock Springs, Wyoming, to brief BLM, FS, and coal-company hydrologists on channel-geometry techniques and the regional salinity model. Analysis of stream temperatures was completed--a regional model was developed that allows estimation of stream temperatures at unmeasured sites. 
PLANS FOR FISCAL YEAR 1979: Emphasis will be placed on completing interpretive reports. First priorities are the reports shown as in progress.

REPORTS PUBLISHED DURING FISCAL YEAR 1978:

Lowham, H.W., 1978, An analysis of stream temperatures, Green River Basin, Wyoming: U.S. Geological Survey Water-Resources Investigation 78-13, $41 \mathrm{p}$.

Engelke, M.J., 1978, Considering the Caudata: Wyoming Wildlife, v. 42, no. 9 , p. 14-15.

PROJECT TITLE: Impacts of economic development and water use on water resources in the Hanna Basin in Wyoming (WY 75-031).

COOPERATING AGENCY: Bureau of Land Management.

PROJECT LEADER: Pamela B. Freudenthal.

FIELD LOCATION: South-central Wyoming.

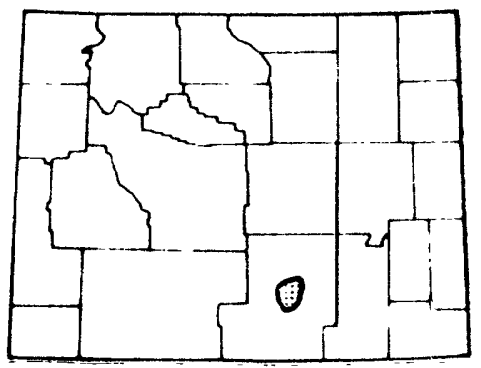

PERIOD OF PROJECT: July 1974 to September 1979.

PROBLEM: The Hanna Basin has over 22,000 acres of land leased for coal mining. Mining, some of which w111 be in water-saturated coal beds, will apply stresses on the hydrologic environment through dewatering and due to new demands for water supplies. Federal and State agencies are concerned about the availability of water and the impact of coal mining on the water resources.

OBJECTIVE: The objectives of the project are to describe the present characteristics of the hydrologic environment, to monitor changes in $i t$, and to evaluate the effects of those changes. At the surface, the objectives are to determine streamflow and water-quality characteristics of streams. In the subsurface, the objectives are to define aquifer characteristics and quality of water.

APPROACH: A network of wells in and around the mines, finished below, in, and above the zones to be mined will be extablished; aquifer tests will be done and quality of water and water levels will be monitored. Gages on the major drainages will be maintained to monitor streamflow, and quality-of-water samples will be collected for salinity and trace-element analyses. 
PROGRESS AND SIGNIFICANT RESULTS: Water levels were measured period-ically in about 70 wells, about 50 water quality samples were collected and analyzed, about 45 wells were cleaned by bailing, anc recovery tests were done after bailing those 45 wells. Four wells in the area were cased. A report was prepared for releasing water quality data (in review process).

PLANS FOR FISCAL YEAR 1979: Emphasis will be placed on finishing the water-quality data report. A water-level and well-data report is planned and also an interpretive report of water quality, poten-tiometric surfaces, and aquifer analyses. Water levels will contirue to be measured periodically.

REPORTS PUBLISHED DURING FISCAL YEAR 1978: None.

PROJECT TITLE: Water resources of the Powder River structural basin in Wyoming in relation to energy development (WY 75-032).

COOPERATING AGENCY: Bureau of Land Management and Department of Energy.

PROJECT LEADER: Mar1In E. Lowry.

FIELD LOCATION: Northeastern Wyoming.

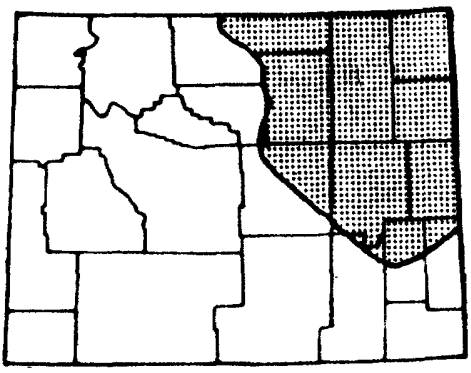

PERIOD OF PROJECT: November 1974 to September 1979.

PROBLEM: The problems are those related to large water requirements for development of energy resources in the water-short Powder RiverBasin and the impacts resulting from such development. An average annual requirement for energy development of 250,000 acre-ft of water per year is projected by 1990. Part of the initial demand could be supplied by surface water and (or) ground water from aquifers of upper Cretaceous or Tertiary age. The impacts of mining, reclamation, transbasin diversions, off-channel and other reservoijss on the shallow aquifers, stream systems, and quality of water is not known.

OBJECTIVE: The objectives of the first phase will be to determine tie adequacy of existing data to describe water availability and assess possible impact of the pending development, and to identify specific subjects that should be studied by the district. The findings of the first phase will be used to identify major thrusts for the second phase, which will constitute the district's program in the basin during the succeeding four years. A data-collection system will be designed, based on findings of the first phase, to meet data needs for thrusts and obtain benchmark information. 
APPROACH: The existing data and data-collection program will be evaluated and a data-collection program, which is coordinated with other governmental and industrial programs, will be implemented. Various study techniques including those for determination of aquifer properties, streamflow analysis, channel geometry, isotope study, biological assay, water budgets, modeling, and geophysics will be explored and those that have merit will be pursued in the second phase of the study.

PROGRESS AND SIGNIFICANT RESULTS: Field work has been essentially completed and, in addition to the two published reports listed, results of parts of the investigation have been described at nine meetings of professional societies. Ground-water studies have produced evidence that the concept of recharge in the topographic high areas of the basin with discharge in topographic lows may be an oversimplification and not valid in predicting impacts of development. Studies of infiltration in small basins indicate it may be possible to assign infiltration values to some of the soils, or soil groups, in the basin. This would greatly enhance the transfer value of this phase of the investigation. During the study, the scope of the ground-water quality investigations was expanded to include the impacts of in-situ coal gasification. This phase of the investigation was done in cooperation with Lawrence Livermore Laboratories.

PLANS FOR FISCAL YEAR 1979: Complete writing of reports describing results of investigations.

REPORTS PUBLISHED DURING FISCAL YEAR 1978:

Feder, G.L., Lee, R.W., Busby, J.F., and Saindon, L.G., 1977, Geochemistry of ground waters in the Powder River coal region; in Geochemical survey of the western energy regions, Fourth Anrual progress report: U.S. Geological Survey Open-File Report 77-872, p. 173-179.

Rankl, J.G., and Barker, D.S., 1977, Rainfal1 and runoff data from smal1 basins in Wyoming: Wyoming State Englneer, Wyoming Water Planning Program Report:No. 17, $195 \mathrm{p}$.

Busby, J.F., and others, 1978, A comparative hydrogeochemical investigation of two western coal regions (abs.): Amer. Assoc. for the Advancement of Science annual meeting, Washington, D. C., Feb. 1978, 1 p.

Busby, J.F., 1978, A geochemical investigation of ground water in tho Powder River Basin, Wyoming (abs.): Amer. Geophysical Union meeting, Miami, Fla., April 1978, 1 p. 
PROJECT TITLE: Hydrology of Paleozoic rocks in the Powder River basin and adjacent areas, northeastern Wyoming (WY 75-033). $1 /$

COOPERATING AGENCY: None.

PROJECT LEADER: William J. Head.

FIELD LOCATION: Northeastern Wyoming.

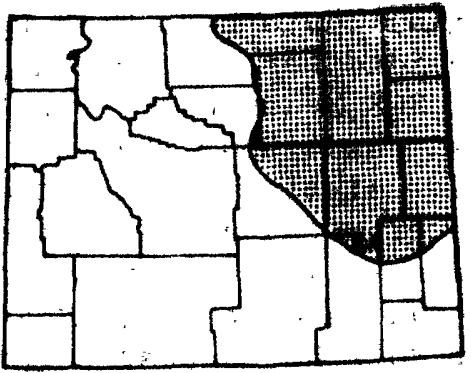

PERIOD OF PROJECT: November 1974 to September 1979.

PROBLEM: Development of energy resources, especially enormous coal deposits, in the Powder River Basin will require a projected increase of 250,000 acre-ft of water per year by 1990. Ground water is more readily available, and will be the principal source of water in the ear1y years of development until large-scale multipurpose water projects are completed. Paleozolc-age carbonate rocks, largely undeveloped, could yield large quantities of water. Development of large water supplies from the Paleozoic rocks depends on the presence of secondary permeability and on the aquifer response to pumping from nearby wells developed in the same aquifer.

OBJECTIVE: The project is designed to derive a conceptual model of the aquifer system to better predict the quantity and quality of water available from the Paleozoic rocks and to predict some of the effects of its development. Principal objectives will be to determine. (1) the distribution, thickness, and physical properties of the aquifer system; (2) the processes that developed the present distribution of aquifer parameters in order to extend point data to other parts of the aquifer system; (3) the potentiometric surface. and chemical quality of the water in the aquifer system; and (4) the. effects of increased development of water from the aquifer system.

APPROACH: All available data for the aquifer system will be collectec and compiled, including data for water wells, oil and gas tests that: penetrated the aquifer, and tests, cores, and chemical analyses of water. Borehole and surface geophysical surveys will be made to evaluate and correlate the physical characteristics of the aquifer tio the water-yielding properties. Natural tracers will be used to determine both the rate and direction of flow. Temperature differences with depth will be obtained to evaluate vertical movement of water. A streamflow analysis will be made to evaluate recharge and undergrour. flow regime. Digital simulation models will be designed to aid in interpreting the aquifer systems and to predict the response to future stresses.

1/ This project is subsidiary to project CR 76-192, described on page 102 . 
PROGRESS AND SIGNIFICANT RESULTS: Geochemical and ground-water modeling efforts were transferred to the regional-1evel study. Geochemical data have been compiled and reports prepared. Support was provided for maintenance and hydrologic and geophysical testing of the USGS Madison test wells. Fifteen gaging stations were operated throughout the year in the outcrop areas (Project WY 00-0C1). Vertical seismic-profile work was completed. Trade seismic data were interpreted and a contract for new selsmic data was let. New gravity data were taken in the Powder River Basin by NOAA (Nationa] Oceanic and Atmospheric Administration). A gravity study was made in Test Hole No. 3 near Billings, Montana, to examine local structure. Several borehole gravity measurements were made in Test Hole No. 1 near Hulett, Wyoming, showing high-quality density and porosity information. Apparent Water Resistivity (Rwa) results for the Madison were mapped and interpreted. The temperatures and temperature-gradient studies were completed. Several geophysical reports were prepared.

PLANS FOR FISCAL YEAR 1979: Support will continue for the USGS Madison test wells. The fifteen gaging stations will continue to be operated. A final regional Bouguer map will be constructed. Borehole gravity will be taken in Test Holes No. 2 near Broadus, Montana, and No. 3 near Billings, Montana, and interpreted. New selsmic data will be taken at the Madison test-hole sites and the data will be geologicelly interpreted. Finally reports on the geophysical efforts will be mete.

REPORTS PUBLISHED DURING FISCAL YEAR 1978:

Head, W.J., Kilty, K.T., and Knottek, R.K., 1978, Maps showing formation temperatures and configurations of the tops of the Minnelusa Formation and Madison Limestone, Powder River Basin, Wyoming, Montana, and adjacent areas: U.S. Geological Survey Open-File Report 78-905, 12 p.

Brown, D.L., Blankennagel, R.K., Busby, J.F., and Lee, R.W., 1977, Preliminary data for Madison Limestone Test Well No. 2, $\mathrm{SE}^{\frac{1}{4}} \mathrm{SE}^{\frac{1}{4}} \mathrm{sec} .18, \mathrm{~T} .1$ N., R. 54 E., Custer County, Montana: U.S. Geological Survey Open-File Report 77-863, 135 p., 4 pl. (197£).

PROJECT TITLE: Evaluation of Paleozolc and alluvial aquifers in the Bighorn Basin, Wyoming (WY 75-034).

COOPERATING AGENCY: Wyoming State Engineer.

PROJECT LEADER: Maurice E. Cooley.

FIELD LOCATION: North-central Wyoming.

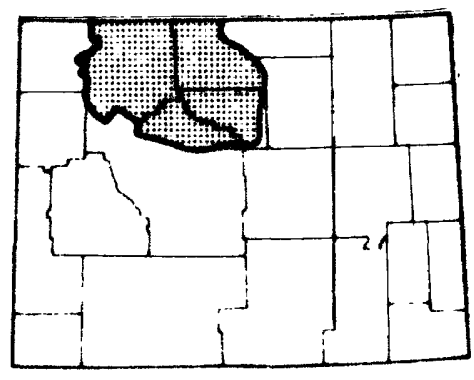


PERIOD OF PROJECT: December 1974 to September 1977 (incomplete).

PROBLEM: In the Bighorn Basin there is a need for development of additional ground-water supplies for irrigation and industrial use. Lack of water for late-season irrigation is a problem now. The best. potential sources include (1) the Artesian aquifer systems in the deeply buried Paleozoic rocks in the eastern part of the basin, and (2) the shallow water-table aquifers in the generally thin, flood-p]ain alluvium along tributaries to the Bighorn River throughout the basir. Additional information is needed about the amount and quality of water that could be developed from the Paleozoic and alluvial aquifers without causing significant decreases in the amount of water in storage, artesian pressures, or streamflow.

OBJECTIVE: For the Paleozoic (artesian) aquifers the objectives are to: (1) Evaluate effects of past withdrawals on storage, artesian pressures, and water quality; (2) delineate areas most favorable structurally for continued development of the aquifer system; and (3) provide additicnal water-quality data of wells, springs, and streams for comparisons with past and future data at the same sites. For the alluvial aquifers the objectives are to: (1) Delineate areas most favorable for ground-water development, particularly the Nowood River (Ten Sleep and Painted Rcrk Creeks), Greybull River, and Ow1 Creek; and (2) evaluate the suitabi1ity of ground water for irrigation, domestic, and industrial use.

APPROACH: For the Paleozoic aquifers the planned approach is to: (1) Make mass measurements of artesian pressures in wells; (2) prepare a pressure map for the two artesian aquifers (Ten Sleep and Bighorn/ Madison); (3) use aerial photographs and satellite imagery to determine folding and fracturing; (4) make conductivity measurements of streams; and (5) collect samples of water from streams and wells. For the alluvial aquifers the planned approach is to: (1) Determine 1ithologic characteristics of the alluvium and prepare a geomorphic map; (2) use electrical resistivity and test drilling to prepare selected profiles; (3) make conductivity measurements of streams; (4) use color photography to determine wet areas and for geomorphologic information; (5) delineate on maps the areas most favorable for groundwater development; and (6) analyze water samples from streams and wells.

PROGRESS AND SIGNIFICANT RESULTS: During the year, four reports giving results of this project were completed. The report on alluvial deposits of the Greybull River valley was reviewed and submitted for approval. The other three reports are nearly ready for review.

PLANS FOR FISCAL YEAR 1979: Plans are to finish processing the remaining reports through review and approval, and publish them in the Water-Resources Investigation/Open-File series.

REPORTS PUBLISHED DURING FISCAL YEAR 1978: None. 
PROJECT TITLE: Algal-growth potential of principal North Platte River reservoirs in Wyoming (WY 76-035).

COOPERATING AGENCY: None.

PROJECT LEADER: Samuel J. Rucker, IV.

FIELD LOCATION: Central Wyoming.

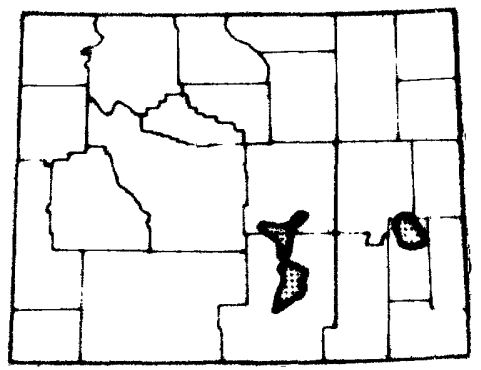

PERIOD OF PROJECT: July 1975 to September 1979.

PROBLEM: Eutrophic conditions may be developing in one or more of the four major reservoirs on the North Platte River (Seminoe, Pathfinder, Alcova, and Glendo). Oxygen depletion could have an adverse effect on recreational use of the reservoirs and on fish habitat. Development of mineral resources, particularly coal mining, is taking place at locations adjacent to one of the reservoirs. There is no information about the present state of algal growth with which to evaluate the seriousness of the problem, to evaluate changes caused by mining activities, or to predict future trends.

OBJECTIVE: The objectives of the study are to (1) determine the extent of algal growth in the four major reservoirs; (2) evaluate trends in algal-growth potential, including effects of effluent from coal mining activities adjacent to the reservoirs; and (3) determine the feasibility of developing a model for predicting algal growth (modeling would be a follow-up project).

APPROACH: The first three years will be devoted exclusively to data collection, with analysis of data and preparation of a report scheduled for the fourth year. Vertical-profile water samples will be collected monthly (May-October) from a boat at sites above the dams and in the principal arms of each reservoir. Sampling will also be done twice each winter. Field parameters will include dissolyet oxygen and temperature. Lab parameters will include nitrogen, ammonia $\left(\mathrm{NH}_{4}\right)$; nitrite + nitrate $\left(\mathrm{NO}_{2}+\mathrm{NO}_{3}\right)$; phosphorus $(\mathrm{P})$; residue, and algal-growth potential (AGP). A set of phytoplankton samples will be collected each year in early spring and in late summer for identification of genera. Graphical and statistical techniques, s'ch as regression, will be used.

PROGRESS AND SIGNIFICANT RESULTS: The storage in Seminoe Reservoir was reduced to approximately one-fourth of the reservoir capacity during the winter period of 1977-78, exposing a large area of the bottom. Five samples of bottom materlal were obtained and analyzed for nitrogen and phosphorous. The nutrient levels were between 580 and 750 milligrams per kllogram for two samples in the Medicine Bow River arm. By mid-August, storage in the reservoir had increased to near the original level. The dissolved-solids concentration was lower than in previous years. Algal growth does not seem to be affected. 
PLANS FOR FISCAL YEAR 1979: It is possible that one more sampling rur will be made on the reservoirs. The main effort for fiscal year $19 \% 9$ will be to complete the data analysis and the final report.

REPORTS PUBLISHED DURING FISCAL YEAR 1978: None.

PROJECT TITLE: Quantitative study of the Tertiary aquifers in southern Laramie County, Wyoming (WY 77-038).

COOPERATING AGENCY: Wyoming State Engineer and Wyoming Department of Economic Planning and Development.

PROJECT LEADER: Marvin A. Crist.

FIELD LOCATION: Southeastern Wyoming .

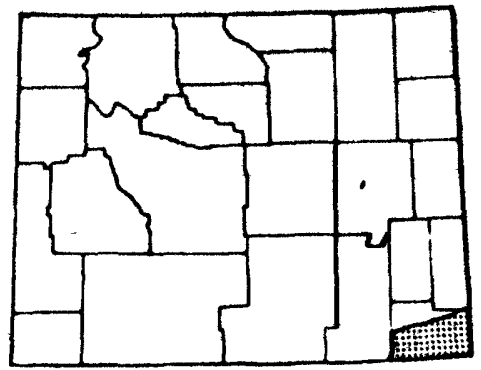

PERIOD OF PROJECT: October 1976 to

December 1978.

PROBLEM: Ground-water development for irrigation in Laramie County has increased significantly the past 3 years. Part of the development is upgradient of two areas that have been designated as Control Areas by the Wyoming State Board of Control. Development is regulated within the Control Areas, but generally is not restricted outside these areas. State water administrators need more information about the development and its effect on water levels and stream discharge, and a way to predict the result of decisions to regulate future development. A model of the ground-water system in the shallow aquifers is needed.

OBJECTIVE: The objectives are (1) to determine the extent of ground-rater development for irrigation, industry, and municipal use, and describe the effect of this development on water levels and stream discharge in the study area; and (2) to provide a means of predicting the effects of alternative ground-water management decisions.

APPROACH: Data will be collected and compiled to make a quantitative analysis of the hydrologic system in the Tertiary aquifers within the study area. A digital model with coarse grid will be prepared utilizing available information. The model would be used to test and verify concepts of recharge and ground-water movement in southern Laramie County. The grid density will be increased in areas of development where more information is available locally. The detalled model would be used to predict the effects of pumping. 
PROGRESS AND SIGNIFICANT RESULTS: The inventory of large-capacity wells was completed and historical and current pumpage were estimated from Irrigated acreage maps prepared by the Wyoming State Engineer's office. A digital model has been developed for the ground-water systems in post-Cretaceous aquifers in an area of about 3500 square miles in Laramie County, Wyoming and adjacent parts of Colorado and Nebraska. The model is to be used by state water administrators as a guide for management of future ground-water development.

PLANS FOR FISCAL YEAR 1979: The final report will be completed and submitted to the Director for approval and published as a WaterResources Investigation/Open-File Report.

REPORTS PUBLISHED DURING FISCAL YEAR 1978: None.

PROJECT TITLE: Water-resources monitoring in the Powder River, south-central, and southwestern coal regions in Wyoming (WY 77-039).

COOPERATING AGENCY: None.

PROJECT LEADER: Stanley A. Druse.

FIELD LOCATION: Northeastern, south-

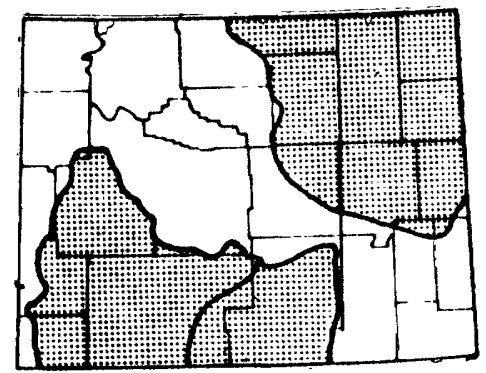
central, and southwestern Wyoming.

PERIOD OF PROJECT: January 1977 to September 1980.

PROBLEM: Coal mining and associated developments of the scale and duration anticipated in major coal producing regions of the West nay have adverse effects on the water resources of these regions. Mine dewatering, changes in land-use patterns, disposal of wastes, streamchannel realignment, and withdrawals of water for industrial and domestic use may significantly alter existing surface- and groundwater systems on a regional basis, limit available supplies, interfere with traditional water uses, and cause deterforation of the remaining water resources.

OBJECTIVE: The objective of the program is to determine the characteristics of the regional water-resources system and to detect and document changes in the system or its components that may be associated with coal mining. 
APPROACH: The existing water-resources monitoring program will be evaluated for its regional surveillance value and additional data sites will be added or existing sites upgraded as needed. Data tha.t continuously or periodically describe ground-water levels and qualj.ty, and streamflows and their quality will be evaluated so that changes may be detected and documented.

PROGRESS AND SIGNIFICANT RESULTS: (1) In the Powder River Coal Regicn, operation of the eleven surface water stations was fully implemented by the contractor, Morrison-Maierle, Inc., Helena, Montana. Field and office evaluations of contractor performance were made several times through the year. The contractor performance has been satisfactory in all phases of data collection and processing. Peak discharges, up to 100-year events, occurred at several contract gages, providing opportunity for fairly complete rating definition. Discharge measurement coverage by the contractor, during the floods, was good; however, several streams could not be measured by current meter because of a lack of highwater measuring structure. The Wyoming District surveyed and computed six indirect determinations of discharge and four step-backwater determinations to aid in rating development. The floods necessitated major rehabilitation at several sites; the work was accomplished by the contractor following the necessary additions to contract specifications. Cableway-A-frame specifications were prepared for three stations, and construction of the A-frames was awarded by competitive bids. A low-flow reconnaissance of discharge and chemical quality was completed by the contractor to supplement the coal-hydrology data base and provide gain-and-loss information for the Northern Great Plains project. The contract for cleaning and sampling observation wells, Drane Drilling, Broadus, Montana, was successfully completed.

(2) South-central and southwestern Coal Regions: The contract: termination date for cleaning and sampling observation wells was extended to provide for additional work in the regions. Work was completed June 30; data obtained are to be used by ground-water projects in the areas.

PLANS FOR FISCAL YEAR 1979: Contractor operation of the eleven streamgaging stations will be monitored for quality assurance. Field data received will be reviewed and processed. Chemical-quality data collection is proposed for four additional sites, pending adequate funding. Specifications will be prepared for construction and installation of three cableways and rehabilitation of a fourth. Present plans are to contract the cableway construction. Indirect determinations of peak flow will be run as needed. A status report, scheduled for fiscal year 1978, will be completed. A proposed report documenting the validity of step-backwater rating development procedures may be started.

REPORTS PUPLISHED DURING FISCAL YEAR 1978: None. 
PROJECT TITLE: Effects of herbicide usage on water quality of selected streams in Wyoming (WY 77-043).

COOPERATING AGENCY: Wyoming Department of Agriculture.

PROJECT LEADER: Joel. R. Schuetz.

FIELD LOCATION: South-central Wyoming.

PERIOD OF PROJECT: June 1977 to

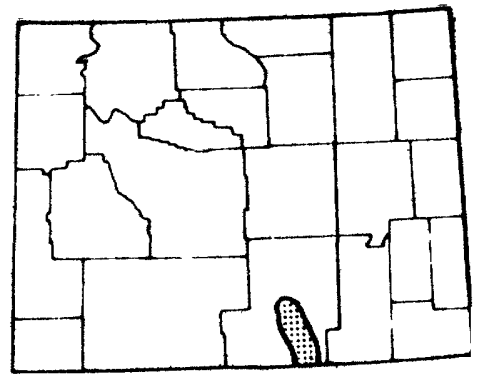
September 1980 .

PROBLEM: Local weed and pest control districts will be spraying the banks of selected streams (and islands in larger rivers) throughout Wyoming with Tordon (4-amino-3, 5, 6-trichloropicolinic acid), Banvel (2-methoxy-3, 6-dichlorobenzoic acid), and 2,4-D. The Wyoming Department of Agriculture needs to know whether or not any of these herbicides appear in the water or bed material downstream from the spraying activity. This problem could be compounded by the extremely low flow expected in reaches of some rivers.

OBJECTIVE: The objectives are to determine the effects of herbicide spraying on water quality and on bed materials in the study reach.

APPROACH: Sets of water- and bed-material samples will be collected upstream and downstream from the spray area before, during, and after the herbicide is applied. Application will last for about 8 weeks, during which sample sets will be collected twice a week immediately downstream. Samples will be analyzed in the Denver Central Laboratory. Results will be examined and the effects on water quality determined.

PROGRESS AND SIGNIFICANT RESULTS: The second sampling run on the North Platte River was made in November 1977. Based on preliminary data for the North Platte River, the scope of the project was increased to include the entire state and the end date extended to 1980 , as new spraying areas were planned by local weed and pest control Distrjcts. Training in sampling procedures was given to state and county personnel in Thermopolis in March and Buffalo in June. Following: spraying, samples were collected and sent to the WRD Central Lab in June and September for 10 sites in northeastern Wyoming and 2 sites in south-central Wyoming. To supplement this project, sampling for dicambra and picloran was added to the 20 pesticide stations in the basic water-quality network (Project WY 00-003). 
PLANS FOR FISCAL YEAR 1979: Spraying and subsequent sampling is expected to continue at the same level as 1978. New streams in other parts of Wyoming probably will be selected by state and local agencies for the spraying program. A report on results to date may be started.

REPORTS PUBLISHED DURING FISCAL YEAR 1978: None.

PROJECT TITLE: A preliminary hydrologic investigation of an in-situ oil-shale retorting site near Rock Springs, Wyoming (WY 78-045).

COOPERATING AGENCY: Environmental Protection Agency.

PROJECT LEADER: Everett A. Zimmerman.

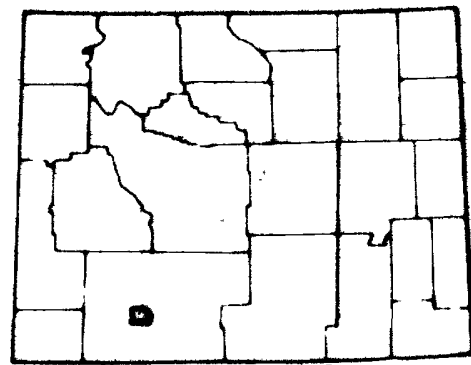

FIELD LOCATION: Southwestern

Wyoming.

PERIOD OF PROJECT: October 1977 to September 1979.

PROBLEM: An in-situ oil-shale retorting experiment was conducted in 1969 by the Department of Energy in the Tipton Shale Member of the Green River Formation at Site 4 near Rock Springs, Wyoming. Prior to combustion, a 20-foot thick section of the oil shale, having extremely low porosity and permeability, was extensively fractured, using electrolinking, hydraulic, and chemical-explosive methods. The Environmental Protection Agency and Department of Energy are concerned about possible effects of the in-situ retorting of oll shale on nearby aquifers and need hydrologic and water-quality data for the site.

OBJECTIVES: The objectives of this study are to collect and publish hydrologic and water-quality data from within and adjacent to the combustion zone during dewatering. 
APPROACH: The Department of Energy will drill into and dewater the burned area at Site 4. DOE will also drill three observation wells in unburned areas adjacent to and on three sides of the burned area. The well sites will be selected using data provided by DOE from core holes drilled before and after the burn and from an infrared surfacetemperature survey made after the burn. Water-level and pumpage data and water samples will be collected from all 4 wells during dewatering. The samples will be split and sent to USGS and DOE laboratories for chemical analysis. The data will be published in an open-file report.

PROGRESS AND SIGNIFICANT RESULTS: Planning of the project and assembling a library of pertinent data was done in fiscal year 1978 . Execution of plans for drilling and sampling were postponed by Department of Energy until at least January 1979 because of susperted communication between the study site and an active burn at anothersite.

PLANS FOR FISCAL YEAR 1979: Plans have been made to (1) locate observation wells, (2) collect water-level and pumping data during dewatering, (3) collect water samples for chemical analysis, (4) tabulate data, and (5) publish and transmit data to Environmental Protection Agency and Department of Energy.

REPORTS PUBLISHED DURING FISCAL YEAR 1978: None.

PROJECT TITLE: Digital model of the Arikaree aquifer in Muleshoe Flat, southeastern Wyoming (WY 78-046).

COOPERATING AGENCY: Bureau of Land Management.

PROJECT LEADER: Dwight T. Hoxie.

FIELD LOCATION: Southeastern Wyoming.

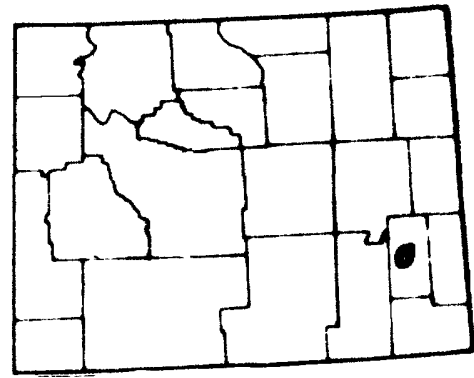

PERIOD OF PROJECT: October 1977 to

September 1978.

PROBLEM: A total of 75 high-yield wells are proposed to be installed in Muleshoe Flat for irrigation purposes. The Bureau of Land Management needs an evaluation of the effects of these withdrawals in order to make a final decision on whether or not to permit the development. 
OBJECTIVE: The objective is to predict the effects of the proposed irrtgation pumpage from 75 high-yield wells on ground-water levels within the study area and on stream-flow in the Laramie River and sybille Creek, which border the area.

APPROACH: Plans are to (1) conduct a hydrogeologic reconnaissance of the Arikaree aquifer, including (a) compilation of surface geologic map, (b) map a configuration of base of aquifer, (c) measirement of water levels and compllation of water-table map, and d) malie seepage runs on principal streams; (2) develop and calibrate a digital two-dimensional flow model; and (3) simulate the proposed pumpage under transient condtions to predict effects on water levels and streamflow.

PROGRESS AND SIGNIFICANT RESULTS: The hydrologic effects of proposed irrigation of 8,320 acres of land with ground water in Muleshoe Flat, a 34 square-mile area in west-central Platte County, Wyoming, were assessed. Results generated by a digital ground-water flow model indicated that at the end of a 40-year pertod ground-water level declines of more than 50 feet can be expected in an area of 12.5 square miles and of more than 200 feet can be expected in an area of 7 square miles. In addition, streamflow depletions of 4,300 acre-feet per year and 4,700 acre-feet per year can be expected in the Laramie River and Sybille Creek, respectively. A program of: hydrologic field-data collection should be undertaken prior to initiation of the proposed irrigation development in order to improve these assessments. The final report was prepared, colleague revier completed, and the report submitted for approval.

PLANS FOR FISCAL YEAR 1979: The final report will be published in tl? U.S. Geological Survey Water-Resources Investigation series.

REPORTS PUBLISHED DURING FISCAL YEAR 1978: None.

PROJECT TITLE: Digital model of the alluvial aquifer in Bates Hole, central Wyoming (WY 78-047).

COOPERATING AGENCY: Wyoming State Engineer.

PROJECT LEADER: Kent C. Glover.

FIELD LOCATION: Central Wyoming.

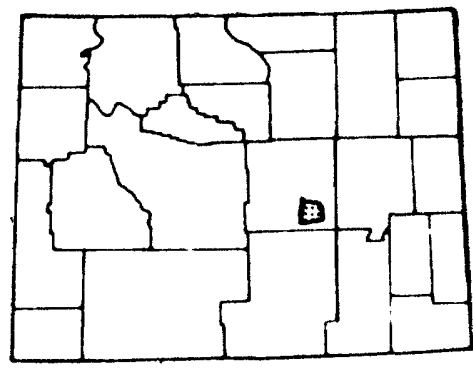

PERIOD OF PROJECT: October 1977 to September 1979. 
PROBLEM: A total of 10 high-yield irrigation wells are proposed for installation in Bates Hole. Existing surface-water diversions virtually depleted the flow of Bates Creek during the irrigation season. The Wyoming State Engineer needs an evaluation of the effects of these withdrawals on streamflow in order to make a final decision on whether or not to permit the development.

OBJECTIVE: The objectives of this study are to define the relationship between Bates Creek and its assoclated alluvial aquifer and to predict the effects of the proposed pumpage on streamflow and water levels within the area.

APPROACH: The approach to be taken in this study is (1) to conduct a hydrogeologic reconnaissance at the alluvial aquifer, including a) collection of 1ithologic and water-table data at approximately 30 wells, this will require drilling 20 observation wells, b) installation of three stream gages, c) compilation of surface geology map, map of base of the aquifer, and water-table maps for irrigation ant non-irrigation seasons, d) aquifer tests of stream depletion, e) soepage runs on Bates Creek, and $f$ ) monitor pumpage and diversions;

(2) to develop a digital two-dimensional ground-water flow model for the area; and (3) to simulate the proposed pumpage to predict the effects on streamflow and water levels.

PROGRESS AND SIGNIFICANT RESULTS: Water levels in approximately 25 wells, including several newly drilled wells, have been monitored monthly. Stream and irrigation discharge has also been measured. A seepage run along Bates Creek was made in March 1978 prior to spring runoff and irrigation. Two wells were driven in Bates Creek to observe the head difference between stream and aquifer. A set of wells were augered on both sides of Bates Creek to observe the potentiometric surface near the creek. A pumpage inventory and irrigated acreage inventory for 1978 has been completed. Maps showing surface geology, base of the alluvium and steady-state potentiometric surface have been prepared. Hydraulic conductivity was estimated from drilling samples and driller logs of previous U.S. Geological Survey studies. Development of a ground-water digital model has begun for the steady-state period of. December 1977 through March 1978.

PLANS FOR FISCAL YEAR 1979: Water levels and stream discharge will continue to be measured. A seepage run is planned for October 1978 to observe changes in the stream-aquifer relationship during an irrigation season. Development of a digital model will continue for the steady-state period of December 1977 through March 1978 and the transient-flow period beginning April 1978. Prediction of water levels and stream discharge in response to planned ground-water pumpage will be made using the developed model.

REPORTS PUBLISHED DURING FISCAL YEAR 1978: None. 
PROJECT TITLE: Digital model of the hydrologic system in the La Grange area, southeastern Wyoming (WY 78-048).

COOPERATING AGENCY: Wyoming State Engineer.

PROJECT LEADER: William B. Borchert.

FIELD LOCATION: Southeastern Wyoming.

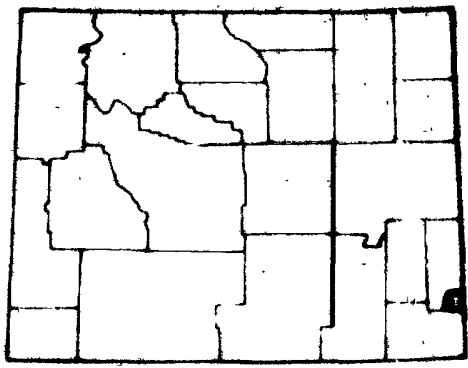

PERIOD OF PROJECT: October 1977 to September 1979.

PROBLEM: Surface water and ground water are used for irrigation in the La Grange area. Surface water stored in a water district reservoly: is supplemented by ground water pumped from district wells adjacent to the reservoir and by springs at the reservoir. The reservoir is down gradient of 27 irrigation wells in a $7 \mathrm{ml}^{2}$ area where waterlevel declines have occurred in the last 3 years. Because of concern about possible additional water-level declines, the Wyoming State Engineer needs to know the effect of current stresses on the syster, as well as a means of predicting future stresses, for water administration.

OBJECTIVE: The objectives are to determine the interrelationship between water in the reservoir and water in the aquifer or aquifers adjacent to the reservoir, to determine the effects of ground-water: pumpage on water levels throughout the area, and to determine the effects of ground-water pumpage on the flow of the springs at the reservoir. The ground-water flow system and the surface- and groundwater relationships will be simulated using a digital model with possible future stresses imposed on the model.

APPROACH: Observation wells w111 be drilled in and near the reservoir and where needed in other parts of the area. Water-level measurements will be made as needed. Preparation of a hydrologic budget will include surface-water inflow and outflow data for two creeks, a pumpage inventory, and estimates of ground-water inflow and outflor, evapotranspiration, and recharge from precipitation. Seepage runs on the creeks and measurements of surface-water diversions w111 be made. The reservoir will be simulated by a pond model used in conjunction with an appropriate digital model that simulates the ground-water flow system. 
PROGRESS AND SIGNIFICANT RESULTS: Sixty-one holes were drilled, including eight holes penetrating the Brule Formation for which electric logs were made, and 45 holes were cased for observation we11s. To determine the interconnection of aquifers, some observation wells, in groups of two or three, were completed in different aquifers. The electric logs and hydrographs for observation wells open to different aquifers under pumping stress indicate the vertical extent of the aquifer system. A water-level recorder was installet on a well between the pumping wells at the reservoir and the irrigation wells upgradient. The hydrograph and pumping schedules help to Indicate the areal extent of water-level decline due to the two pumping areas. Stream-gaging stations were installed on Horse Creak and Bear Creek where they enter the study area. Mass water-1evel measurements were made in the spring and in the fall. A pumpage Inventory and monthly electric-power readings were made. Piezometers penetrating the streambed of Horse Creek were installed. A seepage run was made on Horse Creek and Bear Creek in September.

PLANS FOR FISCAL YEAR 1979: An aquifer test will be made of a well at the reservoir. Using differential leveling, land surface altitudes w111 be determined for selected observation wells and irrigation we11s. Interpretation of data will continue; the data necessary for a ground-water flow model will be complled. Parameter estimation and adjustment will be accomplished using a water-table map prepared in 1957 as a basis for comparison. The model will be operated in a transient mode using short-term and long-term stresses. The responses of the model will be compared with known responses of the flow system.

REPORTS PUBLISHED DURING FISCAL YEAR 1978: None.

PROJECT TITLE: Northern Great Plains

Regional Aquifer-System Analysis,

Wyoming (WY 78-049). 1 I

COOPERATING AGENCY: None.

PROJECT LEADER: Dwight T. Hoxie.

FIELD LOCATION: Northeastern

Wyoming.

PERIOD OF PROJECT: October 1977 to

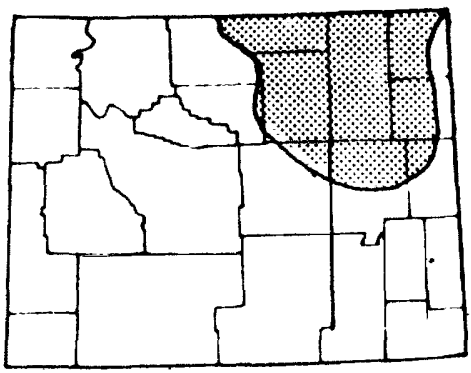

September 1981 .

1/ This project is subsidiary to project CR 78-230, described on page 107. 
PROBLEM: Rapid development of energy resources in the Northern Great Plains will put stresses on heretofore little used aquifers for water requirements and waste disposal. Previous studies have concentrated on comnties or river and structural basins. There is now a need for a regional study of potential aquifers. More knowledge is needed so water development and management alternatives can be evaluated. To provide this knowledge, the Wyoming district will concentrate on aquifers above the Madison and below the Pierre Shale (Cretaceous). The study area is essentially the same as the regional Madison study. Four districts in the Northern Great Plains will participate with coordination by a Central Region staff.

OBJECTIVE: The overall objectives of the project are to provide a quantitative evaluation of the principal hydrologic systems, the quantity and quality of the water in the principal aquifers, the amounts of water available to wells under existing technology, and the effects of withdrawing the water.

The ultimate objective is to provide water managers with technical means of administering and regulating the development of water resources in the project area with emphasis on ground water.

APPROACH: The areal extent of potential aquifers will be defined from previous studies, existing geohydrologic data will be compiled and evaluated, and a program will be developed to selectively collect additional data. The physical parameters of aquifers will be determined by machine processing of digitized geophysical logs. Recharge and discharge from streamflow records, seepage runs, well pumpage, evapotranspiration, and infiltration estimations will be determined. Digital models of the systems will be developed as a predictive means to evaluate alternatives for development of the aquifers and management of the systems. Water quality will be described and geochemical trends and anomalies defined. A data-collection network will be developed for future monitoring of systems.

PROGRESS AND SIGNIFICANT RESULTS: Project staffing was completed. A pilot study to determine evapotranspiration rates within the Powder River Basin of Wyoming and Montana was initiated. The first of two seepage runs and water-quality sampling of perennial streams within the Powder River Basin was completed. The drilling of a deep hydrologic test well in the northern Powder River Basin of Wyoming was begun.

PLANS FOR FISCAL YEAR 1979: Field data collected for the pilot evapotranspiration study in the Powder River Basin will be analyzed and a report prepared. Structural fence diagrams for the Powder River Basin of Wyoming will be prepared. The second of two seepage runs on perennial streams in the Powder River Basin will be completed ant the data from both runs will be analyzed. Data for construction of a digital flow model of the Dakota aquifer over the project area will be assembled. Existing geochemical data will be acquired and used.

REPORTS PUBLISHED DURING FISCAL YEAR 1978: None. 
PROJECT TITLE: High Plains Regional Aquifer-System Analysis, Wyoming (WY 78-050). 1 /

COOPERATING AGENCY: None.

PROJECT LEADER: Charles F. Avery.

FIELD LOCATION: Southeastern Wyoming.

PERIOD OF PROJECT: October 1977 to

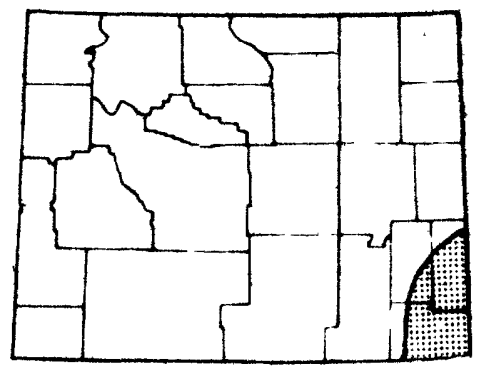
September 1982 .

PROBLEM: The Ogallala Formation and associated rocks are the princiral aquifers underlying the High Plains. The economic future of the High Plains and surrounding area is heavily dependent upon the capacity of the aquifer to sustain withdrawals. Comprehensive knowledge of the aquifer system is needed so that water-management alternatives can be evaluated and the economic life of the aquifer projected. To provide that knowledge, the USGS will do a 5-year study; elght districts, including Wyoming, will participate, with coordination by Central Region staff.

OBJECTIVE: The overall (Reglonal) objectives are to (1) describe the quantity and quality of the water resource and the operation of the hydrologic system; (2) develop a regional water-resources data storage and retrieval system; (3) develop data-collection networks for future monitoring; (4) develop digital models of the aquifer system; and (5) evaluate ground-water management alternatives using the models. The objectives for Wyoming will be to provide hydrogeologic data for the post-Cretaceous formations in southeastern Wyoming to the Regicnal project staff in support of the overall objectives.

APPROACH: The areal extent of aquifer(s) will be defined based on previous studies. Geophysical logs will be examined to help deternine aquifer thickness. About 25 test holes will be drilled. Ground-weter occurrence and movement, aquifer propertles, and recharge will be determined from existing data or from aquifer tests on new wells. Ground-water discharge will be estimated from pumpage and irrigated acreage inventorles, and from streamflow measurements. Approximately 50 water samples will be collected and analyzed. Perlodic mass waterlevel measurements will be made. All existing and new data will be complled and entered into the Regional computer system. Work will be done with the Regional project team to apply Wyoming data to the Regional ground-water model.

\footnotetext{
I/ This project is subsidiary to project CR 78-229, described on page 104.
} 
PROGRESS AND SIGNIFICANT RESULTS: The project chief was assigned in September 1978. Some time was spent becoming familiar with available literature concerning ground water. within the study area. Mass water-level measurements were made in the LaGrange area. Sixty-five test holes were drilled; 49 of those were cased as observation wells.

PLANS FOR FISCAL YEAR 1979: Ground-water quality data will be complled and stored in WATSTORE (National Water Data Storage and Retrieval System). The areal extent of the High Plains aquifer system and the potentiometric surface of the aquifer system during 1978 will be delineated on maps. The drilling program will start as soon as site priorities are established.

REPORTS PUBLISHED DURING FISCAL YEAR 1978:

Weeks, J.B., 1978, Plan of study for the High Plains regional aquifer system analysis in parts of Colorado, Kansas, Nebraska, New Mexico, Oklahoma, South Dakota, Texas, and Wyoming: U.S. Geological Survey Water-Resources Investigations 78-70, 28 p.

PROJECT TITLE: Rate of nutrient release from decomposing plankton and periphyton in Lake De Smet and its outflow, north-central Wyoming (WY 78-051).

COOPERATING AGENCY: None.

PROJECT LEADER: David J. Wangsness.

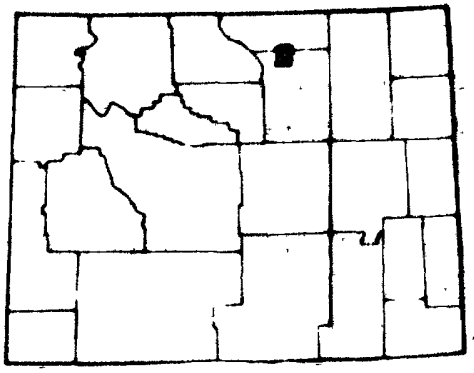

FIELD LOCATION: North-central

Wyoming.

PERIOD OF PROJECT: September 1978 to September 1979.

PROBLEM: There is a lack of understanding about the amount and rate of nutrient (phosphorus and nitrogen) release during algal cell decomposition in lakes and streams. This kind of information would be useful to water managers. The Lake De Smet system is well sulted to this stuly. Originally an abandoned coal pit, the lake receives most of its inflow by diversions from Piney and Clear Creeks. Lake capacity has been increased by dams and dikes. Outflow for irrigation is controlled.

OBJECTIVE: The objective is to determine the amounts of nutrients released during algal cell decomposition and the rate of nutrient release from blue-green algae and diatoms in stream periphyton and lake plankton. 
APPROACH: Untform samples of plankton and periphyton biomass will be. collected and placed in duplicate sample bottles. Algal cells will be killed with a photosynthetic inhibitor and the samples incubatec in the lake and stream. Every 3 hours for 36 hours, and every 6 hcirs for the second 36-hour period a sample will be filtered and analyzed for dissolved forms of nitrogen and phosphorus to the microgram per liter level. Additional samples will be analyzed for total nutrierts, average sample biomass, specie identification and cell counts. Decomposition rates and total nutrient released will be determined.

PROGRESS AND SIGNIFICANT RESULTS: Dissolved-nutrient data were collected during two 72-hour study periods from Lake De Smet and the outlet from Lake De Smet. Twenty samples were collected during each study period. Algal biomass samples were also collected and $\mathrm{pH}$ and temperature measurements were made at the time of sample collection.

PLANS FOR FISCAL YEAR 1979: Data will be analyzed and interpreted ard a report published which will discuss the rate of nutrient release from algal cells upon cell decomposition.

REPORTS PUBLISHED DURING FISCAL YEAR 1978: None.

PROJECT TITLE: Hydrologic conditions in the Wheatland Flats area, Platte County, Wyoming, Part II (WY 79-052).

COOPERATING AGENCY: Wyoming State Engineer and Department of Economic Planning and Development.

PROJECT LEADER: Marvin A. Crist.

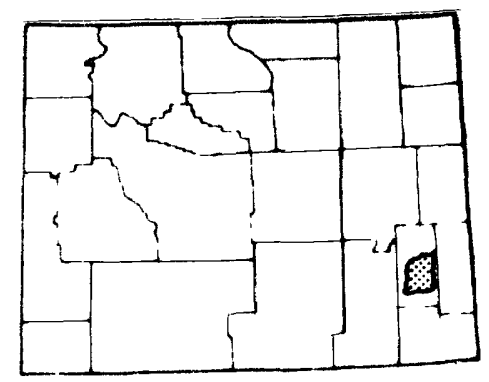

FIELD LOCATION: Southeastern Wyoming.

PERIOD OF PROJECT: Apr11 1979 to March 1981.

PROBLEM: Water is diverted from the Laramie River to irrigate approrimately 40,000 acres of land in the Wheatland Flats area. Ground water is the source for an additional 2,000 acres. Adequate supplies of surface water are available only in years when stream runoff is above normal. Additional water is provided by wells. The increase in irrigation wells from about 85 in 1960 to about 225 in 1978 has resulted in substantially more pumpage of ground water. Consequently some of the shallow wells are no longer productive. Information is needed to determine the effect of ground-water development upon water levels and streamflow. 
OBJECTIVE: The objectives are (1) to determine the extent of present ground-water development for irrigation, industry, and municipal use. and describe the effect of this development upon water levels in the separate aquifers; (2) to determine the effect of imported surface water upon water levels and the effect of imported water and groundwater development upon stream discharge in the area; and (3) to provide a means of predicting the effect of water management decisions.

APPROACH: Wel1-inventory, pumpage, and surface-water use data will be updated. Additional data will be collected to include the adjacent area around Wheatland Flats where irrigation wells have been constructed. An observation-well network will be established and mass water-level measurements will be made in the spring prior to start of irrigation. Seepage runs will be made on all the streams to estimate streamaquifer relationship. Preparation of a water budget will aid in the development of a digital model of the hydrologic system, which will be tied in with two existing models for adjacent areas.

PLANS FOR FISCAL YEAR 1979: The inventory of large-capacity wells will be completed, mass water-level measurements made, and an observationwell network established. Seepage runs will be made on all the streams, and compilation will start of the data to be used for development of a digital model of the hydrologic system.

REPORTS PUBLISHED DURING FISCAL YEAR 1978: None. 
Water-Resources Projects Conducted b! other Districts 
PROJECT TITLE: Yampa River Basin assessment, northwestern Colorado and south-central Wyoming (CO 75-075).

COOPERATING AGENCY: Routt County

Department of Environmental

Hea1 th.

PROJECT LEADER: Timothy Doak Steele.

(Lakewood, Colorado)

FIELD LOCATION: South-central Wyoming and

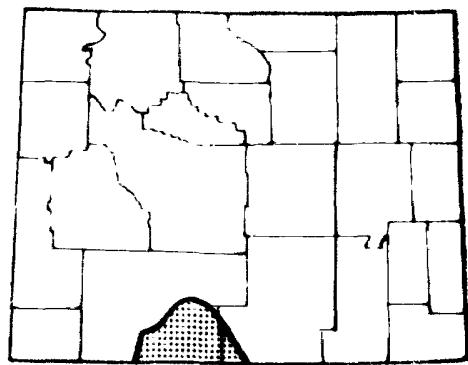
northwestern Colorado.

PERIOD OF PROJECT: April 1975 to December 1977.

PROBLEM: Energy resources in the Yampa River basin in Colorado and Wyoming are being developed. Coal is the dominant energy resource belng developed, with annual production in northwestern Colorado expected to increase from 6.0 million tons in 1976 to more than 20 million tons by 1990 . A substantial part of this mined coal will be converted in the basin to electric power or possibly synthetic gases. Other energy resources in the basin include oil and gas, oil shale, uranium, and geothermal springs.

Decisions affecting policy of energy-resource development need to consider the environmental and economic impact of this development. Energy-resource development leads to increased discharge of residuals to water, air, and land. Residuals are the noneconomic byproducts of energy-development activities. Discharged residuals will modify environmental quality, and attempts to modify or reduce residual discharges will affect both the quantity and quality of the basin's water resources. The availability of water may be a limiting factor to future development of the energy resources in the basin.

OBJECTIVES: The project is designed to assess the availability and quality of the basin's water resources and evaluate the potential environmental and selected socioeconomic impacts of various coalresource development plans proposed by mining and power companies. The possible constraints on water avallability and current uses as a consequence of existing water rights and compact arrangements will be considered. The basin-assessment program is designed to provide Federal, State, and local decision makers with basic environmental information for formulating and evaluating policies for the development of the basin's energy and water resources. 
APPROACH: Ambient hydrologic conditions in the Yampa River basin will be evaluated through interpretation of historic data and collectior of additional data where deficiencies have been identified. Other basin-assessment evaluations include analyses of surface- and grourdwater availability, multireservoir modeling of proposed surface-water development alternatives, remote-sensing applications, travel time and wasteload assimilative capacity analyses, socioeconomic impacts, review of water rights, and investigation of institutional constrajnts and basin compacts which may limit the availability of water for erergyresource development. Existing hydrologic models as well as coalmining and coal-conversion models will be used to simulate the impact of various coal-development plans' on the water-resource systems.

PROGRESS AND SIGNIFICANT RESULTS: Two reports describing the phase I and phase II project work activities have been published. All study work elements outlined in these work-plan reports were carried out, and most have been completed. Several reports documenting results of special topic areas, including contractual studies, are completed or are in process. Summary reports highlighting results for each project phase are in preparation.

PLANS FOR FISCAL YEAR 1979: Complete all reports.

REPORTS PUBLISHED DURING FISCAL YEAR 1978:

Andrews, E.D., 1978, Present and potential sediment yields in the Yampa River Basin, Colorado and Wyoming: U.S. Geological Survay Water-Resources Investigations 78-105, $48 \mathrm{p}$.

Bauer, D.P., Rathbun, R.E., and Lowham, H.W., 1978a, Traveltime, unit-concentration, longitudinal-dispersion, and reaeration characteristics of upstream reaches of two mountain streams (ABS.): American Water Resources Association, 14th annual meeting, Disney World Village, Fla, Nov. 6-10, 1978.

, 1978b, Traveltime, unit-concentration, logintudinal-dispersion, and reaeration characteristics of upstream reaches of the Yampa and Little Snake Rivers, Colorado and Wyoming: U.S. Geological Survey Water-Resources Investigations 78-122 (in press).

Heimes, F.J., 1978, Potential geohydrologic and land-use applicaticns of LANDSAT images and aerial photographs in the Yampa River $B \varepsilon s i n$, Colorado and Wyoming (ABS.): American Geophysical Union Transcript, v. 59, no. 4, p. 273-274.

Heimes, F.J., Moore, G.K., and Steele, T.D., 1978, Preliminary applications of LANDSAT images and aerial photography for determining land-use, geologic, and hydrologic characteristics in the Yampa River Basin, Colorado and Wyoming: U.S. Geological Survey Water-Resources Investigations 78-96, $33 \mathrm{p}$. 
Steele, T.D., 1978, Assessment techniques for modelling water quali.ty in a river basin impacted by coal resource development, in modelling the water quality of the hydrological cycle symposium, Baden, Austria, September 1978, Proceedings: IAHS-AISH Publication no. 125, p. 322-332.

, 1978, The potential impacts of energy development on water resources in the Yampa River Basin--A discussion, in Spofford, W.O., Jr., Ed., resources for future and U.S. Fish and Wildlife Service: Forum on the impact of energy development on the water, fish, and wildlife in the Upper Colorado River Basin, Albuquerque, N. Mex., Oct. 15-16, 1976 Proceedings (in press).

, 1978, An overview of river-basin assessment techniques in an energy-impacted region--Yampa River Basin, Colorado and Wyoming: American Water Resources Association, 13th annual meeting, special symposium on river-quality assessments, Tuscon, Arizona, November 2-3, 1977 (in press).

Steele, T.D., Bauer, D.P., Wentz, D.A., and Warner, J.W., 1978, The Yampa River Basin, Colorado and Wyoming--a preview to expanded resource development and its impact of regional water: resources: U.S. Geological Survey Water-Resources Investigations 78-126 (in press).

Steele, T.D., Wentz, D.A., and Warner, J.W., 1978, Hydrologic reconnaissance of the Yampa River during low flow, Dinosaur National Monument, northwestern Colorado: U.S. Geological Survey Open-File Report 78-226, 10 p.

Warner, J.W., Dale, R.H., and Steele, T.D., 1978, Potential effects of coal-resource development on the ground-water resources of the Yampa River Basin, Colorado and Wyoming (ABS.): American Geophysical Union Transcript, v. 59, no. 4, p. 278.

PROJECT TITLE: Effects of mining and related activities on the shallow ground-water system (MT 75-048).

COOPERATING AGENCY: None.

PROJECT LEADER: Steven E. Slagle. (Billings, Montana)

FIELD LOCATION: Eastern Montana and

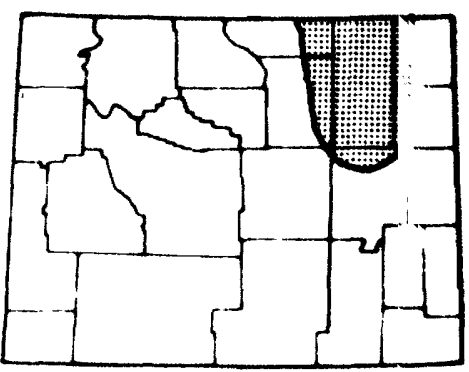
northeastern Wyoming.

PERIOD OF PROJECT: July 1974 to June 1979. 
PROBLEM: Strip mining and the related aspects of coal development can be expected to cause ground-water levels and ground-water quality to change. The public, industry, and government need to know the extent of change in order to take and enforce mitigating measures. Water availability and water quality need to be known in order for other agencies to evaluate alternative sources of water.

OBJECTIVE: The major objectives are (1) to define and understand tr? regional and local flow systems in aquifers above the Pierre Shale; (2) to develop a semi-quantitative conceptual model as a basis for predictive models, (3) to develop predictive models to assess the effects of mining on water levels and the yield of wells and springs; (4) to develop "first estimate" water-quality models to predict rote and direction of movement of poor quality water from spoil banks and other sources; (5) to utilize all of the models to evaluate and revise the data-collection program; and (6) to assure that the datacollection and interpretation (modeling) programs meet the needs of other federal and state agencies.

APPROACH: The accumulated geologic and hydrologic information will be combined to develop conceptual models of the hydrologic system on both large and small scales. Additional data needed for more complete understanding of the hydrologic system will be colelcted. Digita.. models will be developed, first to test and modify the concepts and evaluate the data-collection network, then to predict the effects of mining and related activities on ground-water levels and the disclarge of springs. Using the hydraulic models, development of water-qual.ity models will be attempted to determine or predict leachate migration and the movement of other poor-quality water.

PROGRESS AND SIGNIFICANT RESULTS: A geologic map of the northern Powder River Basin was published and a report on the geochemistry of water in the Fort Union Formation of the Northern Powder River basin was submitted for review. Collection and compllation of water-quality and well data for hydrologic-data reports was completed. Collection and analysis of data from low-flow investigations was continued as was the collection of hydrogeologic data for refinement of isopacl, basal configuration, sand percent, and sand thickness maps. Construction of the hydrologic model continued. Channel geometry studies were initiated to determine mean-annual flow in ungaged streams.

PLANS FOR FISCAL YEAR 1979: Hydrologic-data reports of water quality and well data will be completed. Hydrogeologic maps will be refined for publication as an I-Series report. The report on low-flow studies will be completed. Construction and verification of the hydrologic model will be completed. Channel geometry studies and stream waterquality studies w111 continue. 
Lewls, B.D., and Roberts, R.S., Geology and water-ylelding characteristics of rocks of the northern Powder River Basin, southeastern Montana: U.S. Geological Survey Miscellaneous Investigations Map I-847-D.

PROJECT TITLE: Availability of ground water from aquifers in the Cretaceous and Tertiary systems in the Fort Union Coal Region (ND 75-071).

COOPERATING AGENCY: None.

PROJECT LEADER: Mack G. Croft. (Bismark, North Dakota)

FIELD LOCATION: Northeastern Wyoming, southeastern Montana, and western

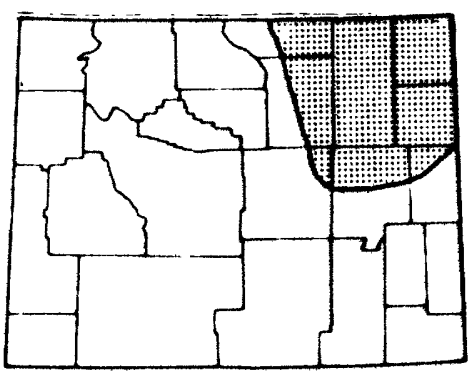
North Dakota and South Dakota (Northern Great Plains).

PERIOD OF PROJECT: JuIy 1974 to June 1977.

PROBLEM: Proposed coal developments in the Fort Union Coal Region of the Northern Plains will be attended by substantial increases in water usage. In much of the region, the only practical source of water for domestic, stock, municipal, and small-scale industrial requirements is ground water from relatively shallow aquifers in rocks of Cretaceous and Tertlary age. However, knowledge of these aquifers is fragmental and Iimited to scattered localities. A systematic and regional appraisal is required for planning, development, and management purposes.

OBJECTIVE: The major objectives are (1) to determine the location, extent, and nature of the major aquifers and confining beds in the Cretaceous and Tertiary systems in the Fort Union Coal Region;

(2) to evaluate the occurence, movement, and availability of ground water, including sources of recharge and discharge; and (3) to determine the chemical quality of the ground water. 
APPROACH: The investigation will be concerned mainly with the compilation, analysis, and interpretations of existing pertinent data from available sources in the states of North Dakota, South Dakota, Wyoming, and Montana. Major aquifers in the Cretaceous and Tertiary systems will be identified, described, and correlated mainly through the use of geophysical and lithologic logs. Three regional hydrogeologic sections will be prepared that will 11lustrate the structural and stratigraphic relationships of the major aquifers. A structural map will be prepared, using the top of the Pierre Shale which, for much of the region, also will represent the lower limit of potable ground water. The final report w111 be prepared in the professional paper or Water-Resources Investigation Series.

PROGRESS AND SIGNIFICANT RESULTS: The project is mainly a compilation of existing published and unpublished data from reports in the Fort Union Coal Region. Water-level and transmissivity maps of the Fox Hills and Tullock (lower Ludlow) aquifer have been compiled. Als? a geologic map of the Fort Union Coal Region and cross sections have been made. All field work and data compllation completed. Report has recelved considerable review and has been updated.

PLANS FOR FISCAL YEAR 1979: Processing of report will be finished and Director's approval obtained for publication.

REPORTS PUBLISHED DURING FISCAL YEAR 1978: None.

PROJECT TITLE: Hydrology of the aquifer(s) in the Madison Group (SD 76-043). 1 /

COOPERATING AGENCY: None.

PROJECT LEADER: Lewis W. Howe11s. (Huron, South Dakota)

FIELD LOCATION: Northeastern Wyoming and western South Dakota.

PERIOD OF PROJECT: July 1975 to June 1980.

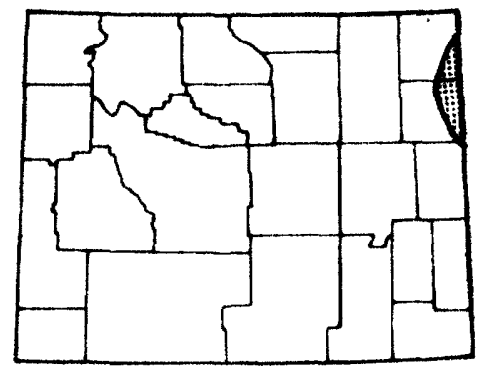

1/ This project is subsidiary to project CR 76-192, described on page 102 . 
PROBLEM: New withdrawals of water from the aquifer(s) in the Madison Group for existing and proposed mining and industrial facilities could greatly exceed 100,000 acre-ft per year within five years. Some concerned persons, including public officials, fear that the aquifer is incapable of supporting a sustained yield of that magnitude and that severe damage may result to other water users in the region.

The problem, therefore, is to delineate the magnitude and distribution (both in space and time) of the water resources in the Madison, and to determine the response of the aquifer to proposed withdrawals of water.

OBJECTIVE: The objectives of the study are (1) to delineate the water resource(s) contained in or integrally related to the Madison Group in South Dakota; (2) to determine the hydrologic regimen of the aquifer(s), with special emphasis on the surface- and ground-water relationship in areas of outcrop, of the aquifer(s) in the Madison Group and to those in underlying limestone rocks of Paleozoic age and of the overlying Minnelusa Formation; and (3) to predict the probable results of removal of large amounts of water from the Madison.

APPROACH: Records, data, and other information available from public and private sources will be collected, evaluated, and interpreted, including analysis of dr111-stem test data by a professional analyst. A datacollection network will be established and operated to meet the objectives of the project. Test drilling, dye tracer tests, aquifer tests, geophysical studies, and other tests and studies will be conducted as needed and feasible. Information will be interpreted ant reports prepared that include structure, isopach, potentiometric, and geochemical maps, and predictions of probable effects of various patterns and magnitude of water resources development. Predictions will be refined from new information available from the data-collention network.

PROGRESS AND SIGNIFICANT RESULTS: The canvass of wells in the western half of South Dakota is complete. The gaging stations on streams in the Black Hills have been installed. Plotting of data for stratigraphic maps is nearly complete. Conversion of well records to System 2000 is about half completed.

PLANS FOR FISCAL YEAR 1979: The compilation and evaluation of data will continue. Gaging stations will be operated and the water-level monitoring program will continue. Ground-water samples will be collected and analyzed from any new wells that are drilled. Coding and conversion of records to ADP will be completed.

REPORTS PUBLISHED DURING FISCAL YEAR 1978: None. 
Water-Resources Projects Conducted by

Central Region Staff 
PROJECT TITLE: Geochemical survey of waters of the western coal regions (CR 74-095).

COOPERATING AGENCY: None.

PROJECT LEADER: Gerald L. Feder. (Lakewood, Colorado)

FIELD LOCATION: Northeastern Wyoming,

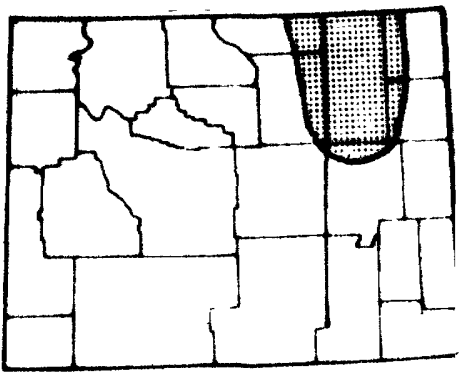
southeastern Montana, western North Dakota, and parts of Arizona, Colorado, New Mexico, and Utah.

PERFOD OF PROJECT: Ju1y 1973 to September 1979.

PROBLEM: The anticipated large scale exploitation of coal or other energy-producing natural materials in the western United States is expected to result in marked changes in the geochemical environment including the quality of waters in the region, and especially the trace-element content of waters. Such changes will result predominantly from effects of strip mining and power production. These changes can be best monitored only if realistic estimates of the predevelopment water quality are known.

OBJECTIVE: It is the goal of this project to efficiently provide data on the "natural" or pre-development geochemistry of the waters of the area, with particular emphasis on trace elements that may have a relationship to health and disease in humans or animals. If time and interest permit, attention may also be given to quantifying changes already produced by existing developments in the area. In addition, the relationships between soils, plants, rocks, and waters, within the study area, w11l be quantified.

APPROACH: During the 1974-75 field season, a hydrogeochemical sampling program will be carried out in the major coal basins in the Rocky Mountain and Northern Great Plains Coal Provinces. Rigorous statistical techniques w1ll be used throughout the study. The data collected w1ll include major chemical constituents, trace elements, and gross alpha and beta actlvity. If high alpha or beta activities are obtained, additional analysis will be made for specific radiochemical elements. All chemical analyses will be done in Water Resources Division laboratories. 
PROGRESS AND SIGNIFICANT RESULTS: Work was performed as a member of. the ground-water Quantity and Quality Committee of the International Poplar River Water Quality Board of the International Joint Commission. The final report with co-investigators was completed. The genera: geochemical environment was found to be similar to the previously studied Northern Great Plains coal regions.

PLANS FOR FISCAL YEAR 1979: Additional sampling and data analysis :n other western coal regions will be done. A study will be made with the help of $\mathrm{R}$. L. Bassett to determine if boron isotopes can be used to trace water movement.

REPORTS PUBLISHED DURING FISCAL YEAR 1978:

Busby, J.F., Feder, G.L., Lee, R.W., Salndon, L.G. 1978, A comparative geochemical investigation of western coal regions (abs);

Abstracts of papers of the 144th National Meeting 12-17 February 1978 AAAS, p. 179.

Feder, G.L., 1978, Possible effects of power production activity on ground-water quality in the Northern Great Plains Coal Province (abs): EOS, Transactions, American Geophysical Union, v. 59, no. 4, p. 278 .

Averett, R.C., Feder, G.L., Grisak, G.W., Lennox, D.H., Miller, M.R., Schneider, A.T., Stan, S., Taylor, 0.J., 1978, Effects of

Saskatchewan Power Corporation power plant on quantity and quality of ground-water in the Poplar River Basin, Saskatchewan-Montana: Report to the International Poplar River Water Quality Board by the ground water Quantity and Quality Committee, 80 p.

PROJECT TITLE: Bedload transport research (CR 74-187).

COOPERATING AGENCY: None.

PROJECT LEADER: William W. Emmett. (Lakewood, Colorado)

FIELD LOCATION: West-central Wyoming.

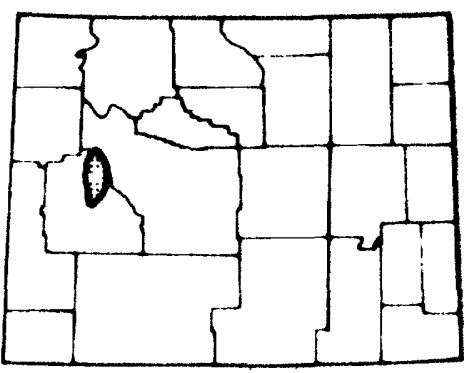

PERIOD OF PROJECT: July 1973 to

September 1980 .

PROBLEM: Of all processes operating in river channels, especially those of practical concern to engineers and others interested in river channel behavior, perhaps the least knowledge is available about the hydraulics and mechanics of bedload transport. Before continuing advances in river channel behavior can be made, some understanding of the behavior of bedload sediment must be made. 
OBJECTIVE: The objectives are (1) to define spatial and temporal variations in bedload transport rate for a single stage of flow; (2) to define change in average magnitude of transport rate over a range in hydraulics of flow; (3) to define change in average magnitude of transport rate over a range in channel geometry; and (4) to analyze the data to evaluate the applicability of available bedload equations, suggest new coefficients for the existing equations, or propose new relations for predicting rates of bedload transport.

APPROACH: The conveyor-belt bedload-transport facility on the East Fork River near Pinedale, Wyoming will be used as a control to evaluate variability factors in bedload transport and to field calibrate the Helley-Smith bedload sampler. The calibrated HelleySmith sampler will be used in the systematic collection of bedload samples, along with the concurrent measurements of streamflow hydraulics from a varlety of sand- and gravel-bed streams. Within the laws of general physics, empirical relations of bedload transport will be stochastically developed and the physical significance of the developed relations will be interpreted.

PROGRESS AND SIGNIFICANT RESULTS: Field calibration of the sedimenttrapping characteristics of the Helley-Smith bedload sampler has been completed and the report submitted for Director's approval. Data analysis and interpretation of information gathered at the conveyorbelt bedload-trap facility and at additional sites through the use of the Helley-Smith bedload sampler will continue. Analysis is underway to facilitate the transfer of information from site-specific field areas to areal application and application to watershed and channel flow/sediment modeling concepts.

PLANS FOR FISCAL YEAR 1979: The Helley-Smith bedload sampler w111 be used to enlarge the data base necessary to evaluate a range in hydraulic and sediment parameters significant to the bedload-transport process. A tracer study will be initiated at the conveyor-belt research facility utilizing fluorescent particles to evaluate the (1) residence time of sediment, (2) average speed of particles, (3) depth of bed material involved in transport, (4) influence of bedforms on transport characteristics, (5) dispersion of bed material, and (6) other related aspects of sediment transport.

REPORTS PUBLISHED DURING FISCAL YEAR 1978:

Emmett, W.W., 1978, Overland flow: In Hillslope Hydrology (M.J. Kirkby, ed.), John Wiley and Sons, 389 p. (pp. 145-176).

Emmett, W.W., Burrows, R.L., and Parks, Bruce, 1978, Sediment transport in the Tanana River in the vicinity of Fairbanks, Alaska, 1977: U.S. Geological Survey Open-File Report 78-290, 28 p. 
Leopold, L.B., and Emmett, W.W., 1977, 1976 bedload measurements, East Fork River, Wyoming: Proc., National Academy of Sciences, v. 74, no. 7, pp. 2644-2648.

Emmett, W.W., and Leopold, L.B., 1977, A comparison of observed sediment-transport rates with rates computed using existing formulas in Geomorphology in Arid Regions (D.0. Doehring, ed.), Proc. 8th Annual Geomorphology Symposium, State University of New York, Binghamton, NY, September 23-24, 1977, pp. 187-188.

Druffe1, Leroy, Emmett, W.W., Schneider, V.R., and Skinner, J.V., 1976, Laboratory hydraulic calibration of the Helley-Smith bedload sampler: U.S. Geological Survey Open-File Report 76-752, 63 p.

Mahoney, H.A., Andrews, E.D., Emmett, W.W., Leopold, L.B., Meade, J.H., Myrick, R.M., and Nordin, C.F., 1976, Data for calibrating unsteady-flow sediment-transport models, East Fork River, Wyoring, 1975: U.S. Geological Survey Open-File Report 76-22, 293 p.

PROJECT TITLE: Reconnaissance techniques for evaluation of rehabilitation potential of energy resource lands (CR 75-104).

COOPERATING AGENCY: Bureau of Land Management.

PROJECT LEADER: Lynn M. Shown. (Lakewood, Colorado)

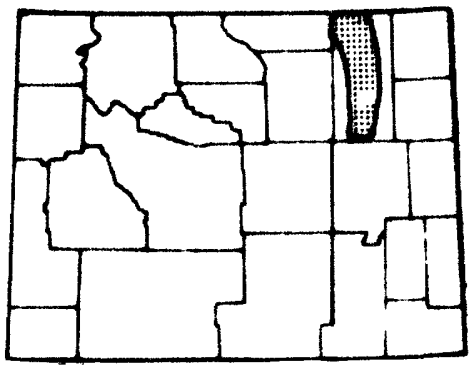

FIELD LOCATION: White Tail Butte EMRIA site, northeastern Wyoming.

PERIOD OF PROJECT: July 1974 to September 1979.

PROBLEM: Hydrologic information with respect to rehabilitation potential is needed by local, state and federal governments, private landowners, energy companies, and others prior to decisions on the leasing, mining plans, and mining of publicly-owned coal and oil shale. The infornation is needed over the next 1 to 5 years, so reconnaissance techniques must be used to obtain much of the necessary data. The two facets of th? problem are: (1) To define the baseline conditions as they exist prior to mining, mostly in areas having sparse hydrologic data; and (2) t:o assess the potential for rehabilitation of the land-water system after mining. 
OBJECTIVES: The purpose of this project will be to refine and apply reconnaissance techniques that will provide mappable and other eas: $1 \mathrm{y}$ assimilated Information to be used as baseline data and in evaluating the rehabilitation potential of lands where energy resource mining and other land-use changes are proposed and in development, verification, and application of hydrologic process and regression models. Data to be collected and interpreted include: Mean annual runoff, 2-, 5-, and 10-year peak flows, sediment yields, soll-vegetation-water relatiors, slope and exposure effects on vegetation and hydrology, reconstruction of topography after assumed mining, channel and hillslope erosion, and channel condition.

APPROACH: The techniques to be used to characterlze watersheds of various sizes are (1) soll-moisture storage associated with vegetation types; (2) estimates of annual runoff by subtracting soil-moirture storage from annual precipitation; (3) the relation of percent bare soil to runoff and sediment yields; (4) index of erodibility by water dispersion; (5) estimates of annual runoff and peak discharges usirs channel measurements; (6) estimates of sediment yield using climate, drainage basin characteristics, and reservoir sediment surveys;

(7) erosion monftoring by resurveying monumented transects; and (8) hillslope, channel, and geologic cross-section analysis with respect to reconstruction of the topography of potential mine areas. Soils, vegetation and runoff and erosion of nearby mine spoils in various states of rehabilitation w11l be investigated.

PROGRESS AND SIGNIFICANT RESULTS: Information on vegetation, vegetationsoll-water relations, and sediment ylelds was prepared for draft Interagency reports on four EMRIA study areas. Rehabilitation potential is relatively high for the Beulah Trench area, North Dakota; is moc'erate to high for the White Tall Butte, Wyoming area; moderate for the Henging Woman Creek, Montana area; and relatively low for the Kimbeto Wash, New Mexico area. Soil-moisture investigations were begun on six of the model basins and vegetation investigations were begun on two of the. basins. Preparations were begun on a presentation to be given on reconnaissance methods at an AGU Symposium on surface-mineable lanc's. Poor results were obtained in a test of Flaxman's sediment-yield equation, using a set of 20 small basins in northeast Wyoming and southeast Montana for which annual sediment yields had been determined by spudding stock ponds. A regression equation, which utilized independent variables similar to those in Flaxman's equation and stock pond secimentyleld data as the dependent variable explained 68 percent of the variation in annual sediment ylelds with a standard error of 26 percent. Data collection was continued at two of the runoff plots in the Piceance. basin, but discontinued at three others because of prototype oil-stale development construction activities. Several new channel cross sections were installed and resurveyed three times to monitor prospective channel-geometry changes caused by ofl-shale development dewatering. 
PLANS FOR FISCAL YEAR 1979: Open-file reports and maps on vegetatior, soll moisture, and sediment yields will be prepared for the Coal Creek, Oklahoma basin, which is to be modeled. Testing of an equation for predicting annual sediment ylelds from small basins in the Powder Fiver basin will be completed. Vegetation, soil-moisture, and sediment-yield information will be collected for two basins to be modeled in Montrna and Colorado. Project personnel will participate more actively in the development of precipitation-runoff-sediment yield models of small basins. The channel cross sections and hillslope transects in the Piceance basin will be resurveyed.

REPORTS PUBLISHED DURING FISCAL YEAR 1978:

Fricke1, D. G., 1978, Hydrologic and geomorphic data from the Picence basin, Colorado, 1972-77: U.S. Geological Survey Open-File Report 78-825, 169 p.

PROJECT TITLE: Sorption of residual organic substances in retort waters by spent oil-shale residues (CR 75-181).

COOPERATING AGENCY: Department of Energy, Laramie Energy Research Center.

PROJECT LEADER: Jerry A. Leenheer (Lakewood, Colorado)

FIELD LOCATION: Southwestern Wyoming

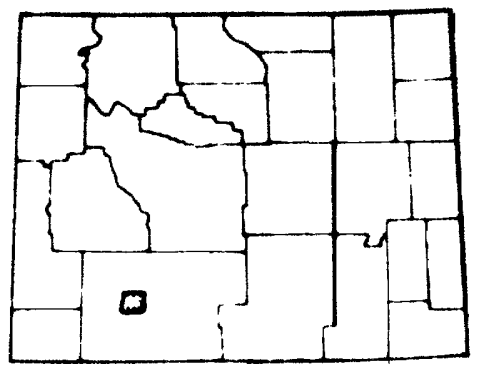
(Rock Springs LERC oil-shale retorting site).

PERIOD OF PROJECT: 1975 to September 1980.

PROBLEM: In-situ oil-shale retorting produces 1 to 5 barrels of wastewater per barrel of oil. This wastewater is the result of free water contained in the oil shale, the dehydration and dehydroxylation of oil shale minerals at the high temperatures of the retorting process, and the partial combustion of the kerogen which produces retort water. The water-oil mixture is an emulsion which is physically separated after pumping from the in-situ retort, and the wastewater is a broin solution containing 500 to 1,000 milligrams per liter dissolved organic carbon.

Because the wastewater must be handled at land surface during oil production, there is some potential for wastewater contact with the soils present at the retort site. Because of concern about the nutrient and toxilogical aspects of the constituents dissolved in the wastewaters, it is important to understand and measure the chemical and physical interactions between the soil and the wastewater. 
The wastewater may be disposed at land surface by using various waste treatment processes, or it may be disposed in the subsurface via injection wells. Because of the concern about the toxilogical aspects of these waste organic solutes, the waste-treatment process selected for use is partially contingent upon the rate of transport of these organic solutes in surface and ground waters after their disposal. Organic solute transport is governed by the rate of water movement, and by solute sorption upon soils, sediments, and aquifer material.

OBJECTIVE: The objective of the proposed research is to determine the chemical and physical effects of soil upon the wastewater composition and wastewater upon soll composition, and to determine the type and magnitude of the organic solute sorption processes which occur upon soil and sediment sorbents associated with the disposal of In-situ-produced wastewater.

APPROACH: This Investigation will be conducted using the wastewaters, natural waters, soils, and sediments associated with the experimental in-situ oil-shale retorting site of the Laramie Energy Research Center, Department of Energy, located near Rock Springs, Wyoming. All waters, soils, and sediments will be supplied by personnel of the Laramie Energy Research Center.

The proposed investigation will directly study only the chemical and physical aspects of soll-wastewater interactions. Also, the sorptive properties of unconsolidated soils and sediment sampled at land surface will be characterized by running adsorption isotherms by the batch process of both fractionated and unfractionated wastewater using dissolved organic carbon to quantify the organic solute concentration. The fractionation procedure (Leenheer and Huffman, 1976) typifies the sorptive interactions of the organic solutes into six characteristic fractions.

PROGRESS AND SIGNIFICANT RESULTS: Interactions between soil and retort waste water were evaluated, and waste water was found to extract both the sesquioxide and organic coatings from soil particles. Soil sorbs organic base solute fractions perferentially to organic acid fractions from retort water, which is the reverse order for processed shale as the sorbent. A first-order soll survey was conducted at an in-situ oll-shale retorting site near Rock Springs, Wyoming to aid in evaluating soil-retort water interactions. A significant finding in retort-water chemistry was the discovery of high concentrations of thlocyanate, which is espectaliy toxic to plants. 
PLANS FOR FISCAL YEAR 1979: The main effort will center on soil-retort water interactions. Soil columns will be constructed in the laboratory and retort water will be applied. A similar study will apply retort water to soil at a field site, and leachate samples will be collected at various depths in the soil profile. Changes in organic, inorganic, and trace-metal solute composition will be evaluated. The main effort in water chemistry will center on the determination of the organic bases in retort water by liquid chromatography. This class of compounds presents the greatest environmental hazard because of mutagenic and carcinogenic properties.

REPORTS PUBLISHED DURING FISCAL YEAR 1978:

Leenheer, J.A. and Huffman, E.W.D., Jr., 1976, Classification of organt.c solutes in water by using macroreticular resins: Journal Researc U.S. Geological Survey, v. 4, no. 6, p. 737-751.

Stuber, H.A., and Leenheer, J.A., 1978, Fractionation of organic snlutes in oil shale retort waters for studies on processed shale:

Preprints, American Chemical Soclety, Division of Fuel Chemistry, v. 23, no. 2, p. 165-174.

PROJECT TITLE: Hydrology of the Madison Limestone and associated rocks in parts of Montana, North Dakota, South Dakota, and Wyoming (CR 76-192).

COOPERATING AGENCY: None.

PROJECT LEADER: E111ot M. Cushing. (Lakewood, Colorado)

FIELD LOCATION: Northeastern Wyoming, southeastern Montana, southwestern North Dakota, and northwestern South Dakota.

PERIOD OF PROJECT: December 1975 to September 1980.

PROBLEM: Major development of coal within the area will place a heary demand on the area's limited water resources. The surface water is poorly distributed in time and space. It is fully appropriated in part of the area, and in the rest of the area its use will require storage reservolrs and distribution systems. Preliminary studies indicate that the Madison Limestone and assocfated rocks might proride a significant percentage of the total water requirements for coal development. However, the effects of large sustained withdrawals of water from these rocks on the hydrologic system are not known. 
OBJECTIVE: The quantity of water that may be avallable from the Madison will be evaluated, the chemical and physical properties of the water defined. The effects of existing developments on potent:ometric head, storage, recharge and discharge, spring flow and strermflow, and pattern of groundwater flow will be determined. Possible hydrologic effects of proposed withdrawals of water for large-scale developments at selected rates and locations will be predicted. Better locations for wells w 111 be determined and also the type of construction and development of deep wells to obtain optimum yields. A network of observation wells and streamflow gages will be designed to monftor effects of additional developments on the hydrologic syster.

APPROACH: Ava1lable geologic and hydrologic data, prior studies, and oil company information will be compliled and evaluated. Borehole and surface geophysical information and other pertinent data will be purchased from oil companies. Structure and stratigraphy will be def:ned, and aquifer boundaries and geologic parameters that control permeability will be determined. These parameters will be translated into hydrologic terms. A test-drilling program will be designed and the aquifer will be drilled and tested. The preliminary digital simulation model of the system will be refined, and a monitoring network will be designed. Predictions will be made about the possible effects of various patterns of water-supply development on potentiometric surface, recharge, discharge, springs, streamflow, and water quality. The monitoring network will be operated and the predictions will be refined.

PROGRESS AND SIGNIFICANT RESULTS: Tectonic and structure analysis of Madison Group and assoclated rocks was continued and preliminary structure and 11thofacles maps were prepared. The geochemical and subsurface geophysical studles were continued. Water-temperature and Rwa maps for Red River Formation, Madison Limestone, and Minnel.usa Formation were completed. Drilling of Madison Limestone test well 3 was begun and at the end of the fiscal year the top of the Madison was reached at a depth of 4,300 feet. A preliminary test Indicated that the shut-In head of the Madison at the test site is more than 1,000 feet above the land surface.

PLANS FOR FISCAL YEAR 1979: Drilling, coring, and preliminary testing of Madison Limestone test well 3 was completed. Selected zones in at least one of the three Madison test wells may be acidized to determine the effect of acid treatment on the yields of water from thesn zones. The geological and geochemical studies will be completed ard reports relating to these studies will be prepared. A large-scale digital model of the geohydrologic section from the top of the Madison to the top of the Precambrian w111 be developed, and an attempt wiJ.1 be made to verify it with existing water-level data. The model wiJ.1 be refined as input data from the Northern Great Plains RASA (Regional Aquifer System Analysis) become available, and the model w111 be ured as a predictive tool for various alternatives of ground-water development. 
REPORTS PUBLISHED DURING FISCAL YEAR 1978:

Brown, D. L., Blankennagel, R. K., Busby, J. F., and Lee, R. W., 1977 , Preliminary data for Madison Limestone test wel1 2, SE $\frac{1}{4} \mathrm{SE} \frac{1}{4}$ sec.18, T.1 N., R.54 E., Custer County, Montana: U.S. Geological Survey Open-File Report 77-863, 135 p.

Cushing, E. M., and Brown, D. L., 1978, The Madison Aquifer Study: Duplicated by authors as a preprint, American Society of Civil Engineers National Convention, Pittsburgh, Pennsylvania, April 27-28, 1978, 11 p.

Brown, D. L., 1978, Wrench-style deformational patterns associated with a meridional stress axis recognized in Paleozoic rocks in parts of Montana, South Dakota, and Wyoming: Montana Geological Society, 24th Annual Conference, 1978, Williston Basin Symposium, p. $17-31$.

Peterson, J. A., 1978, Subsurface geology and porosity distribution, Madison Limestone and underlying formations, Powder River Basin, northeastern Wyoming and southeastern Montana, and adjacent areas: U.S. Geological Survey Open-File Report 78-783, 9 p., 21 figs.

PROJECT TITLE: High Plains regional aquifer-system analysis

(CR 78-229).

COOPERATING AGENCY: None.

PROJECT LEADER: John B. Weeks.

(Lakewood, Colorado)

FIELD LOCATION: Southeastern Wyoming,

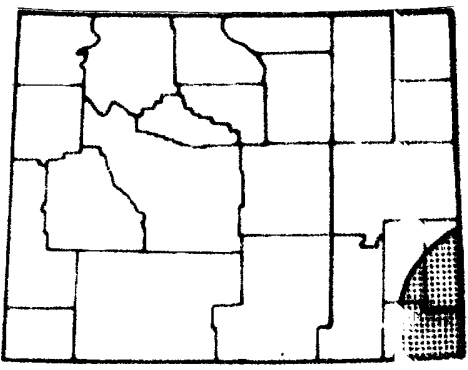
south-central South Dakota, Nebraska, eastern Colorado, western Kansas, western Oklahoma, western Texas, and eastern New Mexico.

PERIOD OF PROJECT: Fiscal years 1978 through 1982. 
PROBLEM: The High Plains is a discontinuous upland area of about $150,000 \mathrm{mi2}$ extending from southern South Dakota to western Texas and eastern New Mexico. The Ogallala Formation is the principal aquifer underlying the High Plains, which includes about 23 percent of the Irrigated land in the United States. The aquifer contains on the order of 2 billion acre-ft of water in storage; but, water is being withdrawn for irrigation in excess of the rate of natural replenishment. The economic future of the High Plains and the surrounding region in elght states (Colorado, Kansas, Nebraska, New Mexico, Oklahoma, South Dakota, Texas, and Wyoming) is heavily dependent upon the capacity of the aquifer to sustain withdrawals.

Several water-management options have been proposed, including those (1) to extend the life of the aquifer by artificial recharge, more efficient soll and water-management practices, and limiting annual withdrawal; (2) to supplement the water in the region by weather modification and water importation; and (3) to allow unrestricted water use. Local, reglonal, and National interests are vitally concernet about the future of the ground-water supply and its impact on the economy of the region. A comprehensive knowledge of the hydrologic system of the High Plains is required so that water-management alternatives can be evaluated and the economic life of the aquifer can be projected.

OBJECTIVE: The objectives of the study of the High Plains aquifer system are (1) to describe the water resource and the operation of the hydrologic system; (2) to develop a regional water-resources (and related) data storage and retrieval system; (3) to design and develop a digital computer model (or models) of the High Plains aquifer system; and (4) to evaluate selected ground-water management alternatives to demonstrate the applicability of the model (or models) and provide a hydrologic basis for the economic evaluation of management alternatives.

APPROACH: The objectives of the study will be accomplished through (1) the assembly, compilation, and analysis of existing data; (2) the collection and analysis of data designed to provide information on parameters for which data are lacking; and (3) the development of computer models. Data collection networks will be initiated in those areas where existing networks are inadequate to quantitatively describe the hydrology of the High Plains. The data compiled and collected will become part of a computerized data-management system which will provide a hydrologic (and related) data file for the entire High Plains region. 
The purpose of the computerized data file is twofold. First, the data file will provide all input data necessary for the development of a regional model of ground-water flow in the High Plains aquifer system. Second, the data file will provide all users with hydroloric and related data on a scale suitable for local interpretation and modeling. The data-management file will be maintained on the U.S. Geological Survey computer at National Headquarters (possibly within System 2000) to provide maximum accessibility to the file. It is intended that the data file will be perlodically updated and maintained for water-resource management purposes beyond the life of this High Plains aquifer study.

Information for several of the hydrologic parameters needed for modeling is not avallable in adequate detall to provide reglonal and (or) historical varlations in the value of the parameter. This is particularly true of recharge, pumpage, and specific yleld data. For these and other parameters where data are sparse or nonexistent, speclal investigations w111 be planned and executed to develop the necessary data or estimation techniques to regionalize the data.

Water-level, pumpage, and recharge records are the primary data sets for which historical data must be developed. It is anticipated that water-level records are generally adequate to describe the historical water-level changes in the Ogallala aquifer. However, it is expected that adequate data are not avallable to describe historical pumpage or recharge for the aquifer. Existing data collection networks for both water levels and pumpage w111 be reviewed, revised, and expanded as necessary to provide an accurate and extensive data base for the fiture. Particular emphasis will be placed on developing a monitoring netwrrk for determining annual pumpage and consumptive use.

Data on the reglonal varlation of specific yield are not available and will have to be developed during this study. It is anticipatet that several methods for estimating specific yleld will be funded and studied by this project. The methods will include both field and computer model studies.

The primary product of this project is a computer model of the High Plains aquifer system capable of predicting the future state of the aquifer system given knowledge of the future stress. It is intended that this model will become a ground-water management tool to aid reglonal, state, and local planners in assessing the impact of management alternatives on the hydrologic and economic future of the aquifer system. The model (or models) will be developed and tested during this study and used to evaluate selected ground-water management alternatives to demonstrate the applicability of the model. 
PROGRESS AND SIGNIFICANT RESULTS: A plan of study was developed and published. Project offices were established and staffed in each of the elght states in the study area. The objectives of the study were established and responsibilities defined for each of the project offices. Review, compilation, and analysis of existing geologic, hydrologic, and water-quality data were started. Design of a computer1zed data-base management system for storage and retrieval of regional data was inftlated.

PLANS FOR FISCAL YEAR 1979: The compilation and analysis of existing data will continue and additional data needs will be defined. Development of the data-base management system will be completed and existing data stored. Regional hydrologic maps will be prepared.

REPORTS PUBLISHED DURING FISCAL YEAR 1978:

Weeks, J.B., 1978, Plan of study for the High Plalns Reglonal AquiferSystem Analysis in Parts of Colorado, Kansas, Nebraska, New Mexico, Okiahoma, South Dakota, Texas, and Wyoming: U.S. Geological Survey Water-Resources Investigations 78-70, 32 p.

PROJECT TITLE: Northern Great Plains regional aquifer assessment

(CR 78-230)

COOPERATING AGENCY: None.

PROJECT LEADER: George A. Dinwiddie. (Lakewood, Colorado)

TIELD LOCATION: Northeastern Wyoming, eastern Montana, western North Dakota, and northwestern South Dakota.

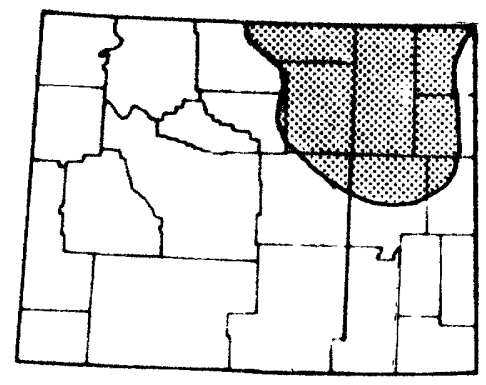

PERIOD OF PROJECT: Fiscal years 1978 through 1980. 
OBJECTIVE: Objectives of the program to assess the availability of water in the Northern Great Plains are those recommended by the National Water Commission in 1973 in 1 ts final report sponsored by the United States Congress, with priorities given to those with falling water tables and deterforating water quality, are to determine: (1) Aquifer boundaries, thickness, saturation, and transmissivity; (2) the sultability of overlying land and wells for artificlal recharge programs; (3) depth of water, quality and temperature of water; (4) the storage capacity at varlous ground-water levels; (5) the source of pollutants found in the aquifer; (6) natural discharge from the aquifer, princlpal withdrawals, sources and amounts of recharge, anticipated ylelds, and the effect of pumping on surface supplies; (7) the extent of past ground-water mining and the estlmated economic' 1ffe of the aquifer under varlous assumptions as to rates of withdrawal; and (8) the susceptibllity of the aquifer to operation $r$ nd management on a "sustained yield" basis.

APPROACH: The first 9 months of the study is designated for collection of existing geologic, hydrologic, and geochemical data. Report outlines will also be prepared the first year, after data compilation is underway.

Drilling, geophysical logging, and testing in test holes is scheduled for late fiscal year 1978, all of fiscal year 1979, and early fiscal year 1980. This phase of the study is delayed to allor adequate time to select drilling sites and to prepare contracts for bid. The large expenditures for drilling, logging, and testing are distributed over all $3 \mathrm{flscal}$ years of the project in order to effectively utilize the funds budgeted for each fiscal year. Testing includes hydraulic testing in zones isolated by packers, and coring for lab tests; including hydraullc and elastic measurements. Waterquality sampling and analysis from each aquifer penetrated by the test holes is also part of testing.

Preliminary design of simulation models is scheduled to begin the second half of f1scal year 1978, in order to design the framework of the models, to ascertain needed data for models, and to conduct pre-liminary simulation of hydrologic systems.

Additional data collection beginning in late flscal year 1978 includes well and spring inventory, aquifer testing, and gain-and-loss studies. Well and spring inventory are needed in the remote parts of the area to provide data on the potentiometric surface, water quality, water use and discharge, and to identify wells suitable for further testing. Aquifer testing of existing wells will continue for a large part of the project duration in order to obtain data needed for modeling and analytical calculations. Gain-and-loss studies in selected streams are needed in order to 1dentify areas of natural recharge by streams, and discharge to streams for exposed aquifers. Repetitive measurements through a 21-month perlod permit calculation of rates of recharge and discharge. 
Preparation of geologic, hydrologic, and geochemical maps begins in late fiscal year 1978 and continues to the middle of fiscal year: 1980. Resulting maps will be published in technical reports and provide input data for hydrologic models, geochemical models, and water-management analyses. Geologic maps include structure-contour: maps, tectonic maps, and 1ithofacies maps. Hydrologic maps include saturated thickness, potentiometric surface, transmissivity, and storage. Geochemical maps include water type as related to flow systems, pollution, and special studies, as needed.

A series of professional papers is proposed to describe results of each project. Chapters of each professional paper would cover the geology, configuration, tectonics, hydrology, and geochemistry of each project. A combined report on modeling of the Madison and Northern Great Plains projects is planned in order to describe multilayered system analysis. The modeling report would describe hydrologic and geochemical modeling, including analysis of watermanagement alternatives.

A preliminary coarse-mesh simulation model will be prepared beginning in fiscal year 1979. The model is proposed to include tlo following areas: Williston Basin; Power River Basin; Hogeland Basin and north-central Montana; and Bull Mountains Basin. The model will integrate all data and simulate the flow systems, including water quality as related to the flow systems. Carefully prepared and calibrated models will be prepared during fiscal year 1979 and fiscal year 1980. The models form the basis for later water-management studies.

Water-management alternatives will be appraised late in fiscal year 1979 and during most of fiscal year 1980. The effects of normal use, drouth, and coal mining on the aquifers, water quality, and land surface will be simulated. Schemes to improve water use will be designed and tested using the simulation models and techniques of systems analysis.

PROGRESS AND SIGNIFICANT RESULTS: A plan of study was written and is in review. An exploratory hole in the Powder River Basin was drilled, tested and sampled. Several staff members were acquired in District and Project offices. Preparation of the data base was started, and special studies were Initiated.

PLANS FOR FISCAL YEAR 1979: Existing data will be assembled and a plan for further data collection made. Staffing in District and Project offices will be completed. Basic data will be entered into the computer data file. Studies of the regional geologic framework, geochemistry, and potentiometric surfaces will continue.

REPORTS PUBLISHED DURING FISCAL YEAR 1978: None. 